UNIVERSIDADE DE SÃO PAULO

FACULDADE DE FILOSOFIA, LETRAS E CIÊNCIAS HUMANAS DEPARTAMENTO DE LETRAS CLÁSSICAS E VERNÁCULAS PROGRAMA DE LITERATURA PORTUGUESA

\title{
A CONSTRUÇÃo dO SUJEITO POÉTICO E A NOÇÃo DE TEMPO NA POESIA DE PAUL VERLAINE E NA DE CAMILO PESSANHA
}

Melissa Andréa Marietti

Dissertação apresentada ao Programa de Pós-Graduação em Literatura Portuguesa, do Departamento de Letras Clássicas e Vernáculas da Faculdade de Filosofia, Letras e Ciências Humanas da Universidade de São Paulo, para a obtenção do título de Mestre em Letras.

Orientadora Profa. Dra. Annie Gisele Fernandes

São Paulo

2008 
A Luis Felipe Maatz Ramos, pela compreensão, carinho e incansável apoio durante a elaboração deste trabalho. 


\section{AGRADECIMENTOS}

Aos meus pais, Marcos Marietti e Márcia de Fátima Ritto Marietti, que sempre me apoiaram e incentivaram meus estudos.

À minha orientadora, Profa. Dra. Annie Gisele Fernandes, que me ensinou muito e contribuiu para o meu crescimento científico e intelectual. Obrigada pela sua paciência e dedicação.

À amiga, Vivian Fernanda de Oliveira dos Santos, que mesmo longe compreendia minhas angústias e me apoiava.

À Fundação de Amparo a Pesquisa do Estado de São Paulo, pela concessão da bolsa de mestrado e pelo apoio financeiro para a realização desta pesquisa. 


\section{SUMÁRIO}

Índice 05

Introdução 07

Capítulo I 09

Capítulo II 40

Capítulo III 64

Capítulo IV 88

Referências Bibliográficas 110

Anexo 125 


\section{ÍNDICE}

Introdução

07

II. Capítulo 1. A Lírica moderna e a concepção de sujeito e de Tempo 10

1.1. A imagem do homem oitocentista na poesia dos precursores: Charles Baudelaire e Cesário Verde 10

1.2. O Simbolismo e a constituição do sujeito poético 20

1.3. A experiência moderna do Tempo na poesia simbolista 37

III. Capítulo 2. Paul Verlaine 40

IV. Capítulo 3. Camilo Pessanha 64

V. Capítulo 4. Paul Verlaine e Camilo Pessanha em perspectiva dialogada convergências e divergências 88

VIII. Anexo 125 


\title{
RESUMO/ABSTRACT
}

MARIETTI, Melissa Andréa. A construção do sujeito poético e a noção de tempo na poesia de Paul Verlaine e na de Camilo Pessanha. São Paulo, 2008, 129 p. Dissertação (Mestrado em Letras) - Faculdade de Filosofia, Letras e Ciências Humanas, Universidade de São Paulo.

\section{RESUMO}

A pesquisa do Mestrado, que se iniciou no primeiro semestre de 2006, tem por objetivo analisar Clepsidra, de Camilo Pessanha, bem como Poèmes Saturniens e Jadis et Naguère, de Paul Verlaine, sob a perspectiva do fluir inexorável do tempo e do sujeito desencantado e recolhido em si mesmo. Trata-se de verificar os procedimentos estéticoliterários, as imagens poéticas e as questões decorrentes desses temas nas obras desses dois simbolistas - um francês e, outro, português - ilustrando possíveis diálogos estabelecidos entre uma e outra.

Palavras-chave Paul Verlaine, Camilo Pessanha, sujeito, tempo, desajuste

\begin{abstract}
The Masters research that began in the first semester of 2006 has the objective to analyse Clepsidra by Camilo Pessanha as well as Poèmes Saturniens and Jadis et Naguére by Paul Verlaine,under the perspective of the inoxerable flowing of the time and of the miserable and introverted subject. It's about verifying the esthetic literary procedures, the poetic imageries and the resulting questions from these themes in the works of these two simbolists, a French and another one, Portuguese, ilustrating possible dialogues established between each other.
\end{abstract}

Keywords Paul Verlaine, Camilo Pessanha, subject, time, disadjustment 


\section{INTRODUÇÃO}

Esse trabalho é continuidade e ampliação do projeto de Iniciação Científica, A noção do tempo e a representação do sujeito em Paul Verlaine e Camilo Pessanha, que foi desenvolvida com bolsa concedida pela FAPESP, de julho de 2004 a dezembro de 2005 e cujo objetivo era estudar as obras Jadis et Naguère e Clepsidra atentando para as relações - de aproximação e/ou de afastamento - que se pode estabelecer entre elas no que concerne à constituição do sujeito e à sua perspectiva de desajuste diante do tempo que flui inexoravelmente.

A Iniciação Científica proporcionou ampliação do conhecimento sobre Paul Verlaine e Camilo Pessanha. O Mestrado apresentou-se como possibilidade de continuidade daquela investigação, por meio da expansão da pesquisa, através do alargamento do corpus e da Bibliografia e do aprofundamento da análise.

O primeiro capítulo da Dissertação trata do Simbolismo português e francês com suas especificidades, mas ambos vistos como poética da modernidade. Nessa perspectiva, salientamos também que os temas propostos para estudo são recorrentes na produção literária que se convencionou chamar de "poéticas da modernidade". Assim, neste capítulo, abordamos as modificações ocorridas no século XIX, nas grandes capitais, e como essas são tematizadas pela Lírica, especialmente nos poemas de Charles Baudelaire e Cesário Verde, ressaltando a importância desses poetas como precursores do Simbolismo e da modernidade.

No segundo e no terceiro capítulos, analisamos poemas de, respectivamente, Paul Verlaine e Camilo Pessanha, objetivando estudar a relação entre sujeito poético e tempo, a concepção de desajuste daquele quanto a este e o modo como esses dois pólos podem 
constituir referência para outros temas recorrentes no Simbolismo, como o desencantamento, o desengano, a apatia, a melancolia, o desejo de morte.

No segundo capítulo, no qual nos detemos nas duas obras de Paul Verlaine, Poèmes Saturniens e Jadis et Naguère, analisamos mais detidamente um poema de cada obra, "Chanson d'Automne" e "Allégorie", respectivamente. Ressaltamos que embora, para muitos críticos, Poèmes Saturniens, primeira obra de Verlaine, constitua-se mais representativa do Parnasianismo do que do Simbolismo, muitos aspectos simbolistas já estão presentes, ainda que de maneira tímida. Além disso, a questão do homem desencantado e do passar do tempo mostra-se marcante, já que esse topos aparece estreitamente ligado à questão da melancolia, que perpassa inúmeros poemas e aparece implicitamente já no título.

No terceiro capítulo, estudamos Clepsidra, de Camilo Pessanha. Esse capítulo constitui-se da análise de composições da obra mencionada, nomeadamente de "Foi uma dia de inúteis agonias" e "Desce emfim sobre o meu coração o olvido", atentando para os traços característicos do Simbolismo enquanto poética de modernidade, para as características específicas do maior simbolista português e para a maneira como o poeta elabora o tema do Tempo e do sujeito desencantado, que se configuram como Leit-motiv em Clepsidra.

Por fim, no quarto capítulo, abordamos os dois autores em paralelo. Verificamos em um poema de cada autor, "Langueur", de Verlaine e "Meus olhos apagados", de Camilo Pessanha, a relação que se pode estabelecer entre eles, seja essa de contigüidade, de aproximação ou de afastamento. Assim, é nossa intenção mostrar que o diálogo entre as obras de Paul Verlaine e de Camilo Pessanha ultrapassa as afinidades formais e a musicalidade, motivos pelos quais a crítica sempre os aproxima, e insere-se na perspectiva da construção do sujeito poético e na sua percepção desajustada do passar do Tempo. 


\section{CAPÍTULO I - A LÍRICA MODERNA E A NOVA CONCEPÇÃO DE SUJEITO E DE TEMPO}

\section{1 - A imagem do homem oitocentista na poesia dos precursores: Charles Baudelaire e Cesário Verde}

A partir da segunda metade do século XIX, o processo de "tecnização" da Europa encontra-se em ritmo acelerado. O progresso da técnica opera múltiplas mudanças nas cidades, sobretudo, nas grandes capitais, das quais se destaca Paris, capital do país mais avançado culturalmente do mundo ocidental no final do século XIX, cenário de revoluções mentais, tecnológicas e culturais. O capitalismo consolida-se; a arte torna-se urbana.

As mudanças nas formas de viver, provocadas pelos avanços do progresso científico e industrial, alteram a relação da arte com a técnica, já que é preciso expressar os novos sentimentos determinados pela vida nas cidades. Assiste-se, portanto, também no campo artístico, significativa alteração no estado das coisas, a fim de se adaptar ao mundo moderno: a arquitetura emancipa-se da arte; difundem-se os panoramas; a pintura concentra-se em reproduzir paisagens; a fotografia emerge como a arte da modernidade, na medida em que atende as necessidades mercantis do mundo burguês; e, na poesia, a cidade é tomada, pela primeira vez, como objeto poético.

Esse mundo urbanizado coloca, no decorrer do século XIX, o homem em constante conflito consigo mesmo, pois o Eu sente-se desencantado com o mundo que criou, uma vez que o progresso não trouxe as prometidas e efetivas melhorias nas condições de vida. Além disso, com o desenvolvimento do capitalismo e das indústrias, o homem tornou-se engrenagem de máquina e passou a valer por aquilo que fabrica, de tal modo que essa 
necessidade industrial e econômica de produzir, cada vez mais, altera os valores da sociedade e traz nova noção tempo.

Pensando, particularmente, em França e em Portugal, pode-se afirmar que emergem dois poetas, Charles Baudelaire e Cesário Verde, que iniciam a lírica moderna e ilustram as mudanças proporcionadas pelo progresso, essas vistas sempre da perspectiva do artista que, como homem moderno, observa e sente as transformações. A poesia toma a cidade como inspiração para o fazer artístico e retrata toda sorte de paisagem; o comum e o vazio emergem densos de carga poética, partilhando da idéia hegeliana de que o poético não se encontra no conteúdo, mas na forma como esse é trabalhado pela imaginação artística ou, em outras palavras, que a poesia não reside intrinsecamente nas coisas, e sim na maneira de apresentá-las. Nos versos abaixo, Baudelaire evidencia que independentemente de valores externos, tudo pode tornar-se Arte:

Quand, ainsi qu'un poète, il descend dans les villes,

Il ennoblit le sort des choses les plus viles,

Et s'introduit en roi, sans bruit et sans valets,

Dans tous les hôpitaux et dans tous les palais. ${ }^{1}$

Esses versos demonstram que a poesia, como toda forma de arte, não se constrói sobre valores morais e externos, mas sim a partir de valores artísticos intrínsecos e independentes. Além disso, Baudelaire concede-lhe a função de sublimar as realidades banais, enobrecendo por meio da imaginação artística toda sorte de paisagem. Assim, a realidade poética difere do mundo exterior e, mais do que isso, é independente desse, já que se fundamenta em princípios artísticos.

\footnotetext{
${ }^{1}$ BAUDELAIRE, Charles, "Le Soleil”, Les fleurs du mal, Paris, Librio, 2002, p.79. Os poemas em língua estrangeira têm tradução transcrita no Anexo. Para os poemas que não possuem publicação em língua portuguesa fizemos tradução livre.
} 
$\mathrm{Na}$ leitura dos poemas de Baudelaire e Cesário, é possível enxergar transformações externas - a consolidação das grandes cidades, as indústrias, as grandes galerias, os novos materiais - e internas - aquelas de ordem íntima, o sentimento e as reações no indivíduo provocados pela modernidade - pelas quais a sociedade do fim do século XIX passou. No entanto, o que mais importa nos poemas não é a expressão pura da realidade, mas a maneira como ela afeta o indivíduo, ou seja, o eu visto na sua relação indissociável com o mundo.

No caso de Baudelaire, a cidade de Paris e suas transformações fornecem substrato ao fazer poético que retrata as mudanças e o progresso, os quais muitas vezes fascinam o sujeito:

\section{LXXXVI - PAYSAGE}

Je veux, pour composer chastement mes éclogues,

Coucher auprès du ciel, comme les astrologues,

Et, voisin des clochers, écouter en rêvant

Leurs hymnes solennels emportés par le vent.

Les deux mains aux mantons, du haut de ma mansarde,

Je verrai l'atelier qui chante et qui bavarde;

Les tuyaux, les clochers, ces mâts de la cité,

Et les grands ciels qui font rêver d'éternité.

Il est doux, a travers les brumes, de voir naître

L'étoile dans l'azur, la lampe à la fênetre,

Les fleuves de charbon monter au firmament

Et la lune verser son pâle enchantement

Je verrai les printemps, les étés, les automnes ;

Et quand viendra l'hiver aux nieges monotones,

Je fermerai partout portières et volets

Pour bâtir dans la nuit mes féeries palais.

Alors, je reverais des horizons bleuâtres,

Des baisers, des oiseaux chantant soir e matin,

Et tout ce que l'Idylle a de plus enfantin.

L'Émeute, tempêtant vainement à ma vitre,

$\mathrm{Ne}$ fera pas lever mon front de mon pupitre ;

Car je serai plongé dans cette volupté

D'évoquer le Printemps avec ma volonté,

De tirer un soleil de mon coeur et de faire

De mes penser brûlants une tiède atmosphère. ${ }^{2}$

\footnotetext{
${ }^{2}$ Ibidem, "Paysage", p. 78.
} 
Não por acaso, esses versos abrem Tableaux Parisiens, grupo de poemas de Les Fleurs du mal, no qual o poeta propõe-se a, tal qual um pintor, retratar a cidade de Paris. No entanto, ainda que se possa pensar em quadros dessa capital, eles são pintados, ou poetizados, segundo a ótica de um sujeito específico que imprime nessas paisagens urbanas suas visões. A poesia baudelairiana, como toda poesia moderna, que nasce nesse período, recusa-se a ser apenas mimese; ela é, especialmente, distorção da realidade segundo parâmetros pessoais e artísticos. Tal projeção da visão interior sobre o mundo exterior permite a correspondência entre o íntimo e a realidade exterior, a interação entre subjetivo e objetivo.

A imagem de Paris como capital do século XIX, do seu progresso cultural e tecnológico, das inovações próprias da cidade junta-se a elementos naturais: a iluminação artificial desponta lado a lado com as estrelas, "étoile dans l'azur, la lampe à la fênetre"; além disso, a imagem dos rios, os quais não são mais compostos por água, mas por fumaça "Les fleuves de charbon monter au firmament", demonstra essa reunião de elementos opostos na criação de uma nova realidade que provoca fascínio no sujeito. A artificialidade da modernidade interessa mais ao poeta do que a naturalidade do campo e o discurso poético é construído sob a perspectiva de não somente representar, mas de, através da linguagem, criar um mundo novo que muitas vezes perde contato com o real. Dessa maneira, afirma-se também nesses versos o papel criador da imaginação, já que o poeta assegura de que, se o externo mostrar-se incapaz de fornecer elementos para o fazer artístico, caberá a imaginação do sujeito evocar e criar as mais diversas paisagens: “D’évoquer le Printemps avec ma volonté".

O fascínio pela modernidade de Paris não é somente da perspectiva do material; o movimento próprio das grandes cidades, seu fervilhar urbano é também motivo de deslumbramento. Uma parte dessa capital abre-se, principalmente à noite, em inúmeras 
atividades culturais - teatros, bares e restaurantes - e outras "imorais", como a prostituição e o roubo. A grande cidade nunca pára, encontra-se sempre numa agitação constante, como podemos observar abaixo:

La prostituition s'allume dans les rues:

Comme une fourmilière elle ouvre ses issues:

Partout elle se fraye un occulte chemin,

Ainsi que l'ennemi qui tente un coup de main:

Elle remue au sein de la cité de fange

Comme un ver qui dérobe à l'Homme ce qu'il mange.

On entend ça et là les cuisines siffler,

Les thêâtres glapir, les orchestres ronfler;

Les tables d'hôte, dont le jeux fait les délices,

S'emplissent des catins et d'escrocs, leurs complices,

Et les vouleurs, qui n'ont ni trêve ni merci,

Vont bientôt commencer leur travail, eux aussi,

Et forcer doucement les portes et les caisses

Pour vivre quelques jours et vêtir leurs maîtresses. ${ }^{3}$

Quanto a Cesário Verde, em "Sentimento dum Ocidental", o que avulta para o leitor, mais do que a descrição das mudanças da modernidade, é o sentimento - que aparece já no título da composição - do homem moderno, particularmente do português, que as experimenta passeando pela capital de Lisboa. Em "Sentimento dum Ocidental", o sujeito, ao caminhar por Lisboa, retrata a cidade e seus traços, esses ora de modernidade, ora de miséria, decorrentes, muitas vezes, das transformações impostas por aquela, que provocam certo pathos particular no sujeito, que se diz enjoado e perturbado pela nova tecnologia, a qual se mistura com a miséria característica de alguns indivíduos que vivem na cidade. Surge de seus versos uma Lisboa triste, melancólica e medíocre e também as modificações sociais oitocentistas, por exemplo, o gás, os edifícios, a via férrea, os lojistas:

Nas nossas ruas, ao anoitecer, Há tal soturnidade, há tal melancolia, Que as sombras o bulício, o Tejo, a maresia Despertam-me um desejo absurdo de sofrer

\footnotetext{
3 Ibidem," XCV Le Crépuscule du Soir", p. 90.
} 
O céu parece baixo e de neblina,

$\mathrm{O}$ gás extravasado enjoa-me, perturba;

E os edifícios, com chaminés, e a turba,

Toldam-se duma cor monótona e londrina.

Batem os carros de aluguer, ao fundo,

Levando à via férrea os que se vão, Felizes!

Ocorrem em revista exposições, paises:

Madrid, Paris, Berlim, S. Petersburgo, o mundo!

Semelham-se a gaiolas, com viveiros,

As edificações somente emadeiradas:

Como morcegos, ao cair das badaladas,

Saltam de viga em viga os mestres carpinteiros.

Voltam os calafates, aos magotes,

De jaquetão ao ombro, enfarruscados, secos;

Embrenho-me a cismar, por boqueirões, por becos,

Ou erro pelo cais a que se atracam os botes

E evoco, então as crônicas navais:

Mouros, baixéis, heróis, tudo ressuscitado!

Luta Camões no Sul, salvado um livro a nado!

Singram as soberbas naus que eu não verei jamais!

E o fim da tarde inspira-me; e incomoda!

De um couraçado inglês vogam os escaleres;

E em terra num tinir de louças e talheres

Flamejam, ao jantar, alguns hotéis da moda.

Num trêm de praça arengam dois dentistas;

Um trôpego arlequim braceja numas andas;

Os querubins do lar flutuam nas varandas;

Às portas, em cabelo, enfadam os lojistas!

Vazam-se os arsenais e as oficinas;

Reluz, viscoso, o rio; apressam-se as obreiras;

E num cardume negro, hercúleas, ganhofeiras,

Correndo com firmeza, assomam as varinas.

Vem sacudindo as ancas opulentas!

Seus troncos varonis recordam-me pilastras;

E algumas, à cabeça, embalam nas canastras.

Os filhos que depois naufragam nas tormentas.

Descalças! Nas descargas de carvão,

Desde manhã à noite, a bordo das fragatas;

E apinham-se num bairro aonde miam gatas,

E o peixe podre gera focos de infecção! $!^{4}$

\footnotetext{
${ }^{4}$ VERDE, Cesário, "O Sentimento dum Ocidental", O livro de Cesário Verde, Rio de Janeiro, Nova Aguilar, 1976, pp. 73- 74.
} 
Como ocorre no poema de Baudelaire mencionado acima, nesses versos de Cesário as modificações e inovações trazidas pelo progresso são tematizadas. A nova arquitetura das cidades, os novos materiais como ferro - pela primeira vez um material artificial é utilizado na história da arquitetura - e o vidro - empregado nas grandes construções -, as estações de trem, a iluminação a gás e o surgimento das galerias como centros comerciais são conseqüências do avanço da técnica e da reconfiguração no modo de produzir. Esses elementos insistem na perspectiva de que o que importa efetivamente é produzir em larga escala e ampliar lucros, para satisfazer mercados cada vez mais ávidos por produtos e, sobretudo, numa perspectiva de que as coisas e o homem somente valem nessa conjuntura produção/mercado/lucros.

Nos versos de Cesário, o que salta aos olhos é o contraste que a modernidade traz a cidade de Lisboa: o progresso é retratado lado a lado com a miséria humana. O gás, as construções e os edifícios, bem como as exposições da tecnologia, os lojistas, a moda, enfim, a cultura capitalista convive com o cheiro de peixe podre que "gera focos de infecção". Essa exibição de realidades divergentes mostra que o progresso da ciência não trouxe todas as melhorias que prometera para homem, ou ainda, que as benesses da modernidade não são para todos.

A cidade de Lisboa é descrita de maneira singular; o poeta, ora nos oferece a interioridade do sujeito, ora a paisagem exterior. De fato, em suas composições, Cesário, nas tomadas de cena, nas imagens em que apresenta o real circundante, parece antecipar, em muitas décadas, o cinema e suas mudanças de foco, visto que a descrição dos elementos externos de Lisboa é entrecortada constantemente pela interioridade do sujeito. A realidade amalgama-se com os sentimentos do indivíduo, cujo caminhar por Lisboa insere-o em certo processo de cisma, permitindo o corte com a realidade exterior para seus 
devaneios. Assim, o real é desencadeador de fatos, episódios e sentimentos guardados na memória do indivíduo - como ocorre na passagem em que recorda Camões, salvando um livro a nado.

A imagem do flaneur, sujeito que vai passando pelo mundo meio suspenso da realidade, é marcante nesse final de século e também nos poemas de Cesário e de Baudelaire. Essa idéia, que será desenvolvida pelos simbolistas, tem raízes no Romantismo, mais propriamente em Rousseau, cuja obra Reveries d'un promeneur solitaire retrata o indivíduo que escapa do real para mergulhar em certo tempo e mundo interior. Tanto em Tableaux Parisien como em "Sentimento dum Ocidental" estamos diante de um sujeito que ao mesmo tempo em que se encontra em meio à cidade, em meio a suas novas formas de viver, sente-se fora dela, de um Eu que guarda distância e apenas observa, que, caminhando na multidão, mostra-se sozinho:

E eu, de luneta de uma lente só, Dou assunto a quadros revoltados; Entro na brasserie; às mesas de emigrados, Ao riso e à crua luz joga-se dominó. ${ }^{5}$

Os versos acima foram publicados no centenário comemorativo da poesia de Camões; ao caracterizar o sujeito poético como o indivíduo com "luneta de uma lente só" Cesário faz referência irônica a Camões que possui um olho só. Além disso, a presença do grande poeta português faz reforçar a nostalgia da poesia de Cesário; em Portugal a questão da decadência, comum nos oitocentos em toda a Europa, é marcada pela presença da nostalgia de um passado mercantilista, cuja glória não pode mais retornar.

A modernidade em Baudelaire e em Cesário apresenta duas faces. Em Baudelaire, de um lado, ela é representada pelo mundo da cidade grande, com todas as características que lhe são próprias, sua ausência de vegetação, sua feiúra, asfalto, iluminação artificial;

\footnotetext{
${ }^{5}$ Ibidem, "Sentimento dum Ocidental" (em parte II Noite Fechada), pp. 75 -76.
} 
esses aspectos são vistos como decadentes na medida em que, para o poeta, eles promovem diminuição progressiva da alma, visto que demonstram domínio do material e atrofia do espírito. Por outro lado, essa modernidade é elemento de fascinação, pois na grande cidade moderna Baudelaire não enxerga somente a decadência do homem, já que emerge desse novo universo uma misteriosa beleza, que o fascina e lhe serve de inspiração.

Em Cesário, tem-se de um lado a modernidade e suas inovações tecnológicas que já provocam cansaço, pois o sujeito, a partir de então, desencantado e melancólico, enxerga o progresso como ilusório, na medida em que não trouxe as melhorias que o homem esperava. Por outro lado, tem-se a miséria do povo português e, também, a miséria interior do sujeito, que convive com as transformações do mundo moderno, as quais não foram suficientes para suprir as necessidades materiais e, sobretudo, ônticas, cujo peso esmaga o Eu e acentua seu cansaço. Tal sentimento é patente nestes versos:

E saio. A noite pesa, esmaga. Nos

Passeios de ladejo arrastam-me as impuras

Ó moles hospitais ! Sai das embocaduras

Um sopro que arrepia os ombros quase nus.

Mas tudo cansa! apagam-se nas frentes

Os candelabros, como estrelas, pouco a pouco;

Da solidão regouga um cauteleiro rouco;

Tornam-se mausoléus as armações fulgentes.

"Dó da miséria!...Compaixão de mim..."

E, nas esquinas, calvo, eterno, sem repouso,

Pede-me sempre esmola um homenzinho idoso,

Meu velho professor de latim! ${ }^{6}$

Os versos retratam o cansaço do homem moderno e terminam com a imagem de um professor de Latim, na miséria, pedindo esmola. O progresso da técnica relegou a obsolescência os saberes antigos, presentificados naquelas estâncias pela imagem do

\footnotetext{
${ }^{6}$ Ibidem, "Sentimento dum Ocidental”, “Ao gás”, pp. 77-78.
} 
professor de latim; esses depois das novas descobertas da ciência, do positivismo, do darwinismo não têm mais lugar na sociedade.

O indivíduo no final do século XIX sente-se enjoado, nauseado pela cidade que se abre como "vale escuro das muralhas", pois esconde, esmagando no seu interior, nas galerias, caracterizadas como "nebulosos corredores", na "massa irregular de prédios sepulcrais", o indivíduo, "os emparedados", ou seja, trata-se de apresentar a miséria humana na perspectiva mais dolorosa possível - a do esmagamento do homem pela técnica. A tensão destes versos é estabelecida pela grandeza do progresso representado pelos "prédios sepulcrais, com dimensão de montes," em oposição aos tipos de indivíduos, ilustrados como "bebedores", "dúbios caminhantes" e "imorais":

Mas se vivemos, os emparedados,

Sem árvores, no vale escuro das muralhas!...

Julgo avistar, na treva, as folhas das navalhas

E os gritos de socorro ouvir estrangulados.

E nestes nebulosos corredores

Nauseiam-me, surgindo, os ventres das tabernas;

Na volta, com saudade, e aos bordos sobre as pernas,

Cantam de braço dados uns tristes bebedores.

Eu não receio, todavia, os roubos;

Afastam-se, a distância, os dúbios caminhantes;

E sujos, sem ladrar, ósseos, febris, errantes,

Amareladamente, os cães parecem lobos.

E os guardas, que revistam as escadas,

Caminham de lanterna e servem de chaveiros;

Por cima, as imorais, nos seus roupões ligeiros,

Tossem, fumando, sobre a pedra das sacadas.

$\mathrm{E}$, enorme, nesta massa irregular.

De prédios sepulcrais, com dimensões de montes,

A Dor humana busca amplos horizontes,

E tem marés de fel como um sinistro mar! ${ }^{7}$

${ }^{7}$ Ibidem, “IV Horas Mortas”, pp. 79-80. 
O sentimento de decadência do homem moderno, cuja raiz encontra-se no mal de vivre romântico, aparece de modo marcante em Cesário e Baudelaire. Tal angústia dominará toda a poesia simbolista do final do século, ampliando-se em significações e variedades, a fim de traduzir a crise coletiva do racionalismo e do utilitarismo. O progresso da técnica e das ciências físico-naturais e também sociais, que edificaram o modelo de racionalidade científica, cujos princípios baseiam-se em idéias mecanicistas, na análise racionalista e na descrição reducionista, propunha extinguir todos os problemas do homem, inclusive suas dúvidas ontológicas, condenando as religiões e a metafísica à obsolescência. A decepção com a técnica e a com a ciência, como solucionadora das questões sociais e espirituais, provoca atitude existencial de "des-encanto", já que o homem foi tirado do encanto de que a ciência resolveria todos os problemas. O sentimento de "des-encanto" leva o homem ao "des-engano", ou seja, o indivíduo desencantado passa a reconhecer que outrora se enganara acreditando que a resolução dos problemas dar-se-ia pela ciência e tecnologia.

Esses sentimentos de "des-encanto" e "des-engano" que aparecem na poesia de Cesário e Baudelaire são abundantes em toda lírica finissecular, muitas vezes ilustrados pela imagem de castelos desfeitos, os quais simbolizam o acabar-se das ilusões. Estes versos de Pessanha elucidam, por exemplo, as quimeras desmanchadas do homem do final de século, a partir da imagem das rosas desfolhadas pelos ventos, de castelos que cedo desmoronaram:

Floriram por engano as rosas bravas No inverno: veio o vento desfolhá-las... Em que cismas, meu bem? Por que me calas As vozes com que há pouco me enganavas?

Castelos doidos! Tão cedo caístes!...

Onde vamos, alheio o pensamento,

De mãos dadas? Teus olhos, que um momento 
Prescrutaram nos meus, como vão tristes! ${ }^{8}$

\subsection{O Simbolismo e a constituição do sujeito poético}

O Simbolismo desponta como poética de renovação literária e estética de contraposição ao Realismo e de contestação social da vida moderna, por meio da retomada e da reelaboração de alguns princípios românticos, sobretudo do Romantismo alemão, como: retorno ao idealismo e ao misticismo; afirmação do desconhecido; nova maneira "shopenhauerniana" de enxergar a arte como única compensação, na medida em que, ao mesmo tempo em que esta se configura como repúdio ao universo descaracterizado, é também refúgio temporário frente a essa mesma realidade, que se mostra, como afirma o sujeito desencantado destes versos de Verlaine, cada vez mais sem sentido:

J'ai vu que tout est vain sous les soleil

Qu'on vive, ô quelle délicate merveile,

Tant notre appareil est une fleur qui plie! !

Embora a idéia da futilidade da vida não seja nova, no Simbolismo, o desencanto com a realidade e falta de sentido da existência assumem especificidades e ligam-se a questão do fazer poético, criando novas perspectivas para essa questão ôntica. A poesia emerge como possibilidade de construção de outra realidade por meios outros que não a mimese aristotélica ou a interioridade platônica. Trata-se agora de ter como elementos fundadores do fazer poético os sentidos, a percepção sensorial, a lembrança, a memória. A realidade, portanto, como já visto em Baudelaire, assume características próprias e

\footnotetext{
${ }^{8}$ PESSANHA, Camilo. "San Gabriel", Clepsydra ( edição crítica de Paulo Franchetti), Lisboa, Relógio D’Água Editores, 1995, pp 25-26

9 VERLAINE, Paul, "Vers pour être Calomnié.", Jadis et Naguère, Oeuvres Poétiques Completes, Paris, Gallimard - Pléiade, 1948, p. 25: "Eu vi que tudo sob o sol é vão!"(trad.livre).
} 
independentes, na medida em que a referencialidade é transferida do objetivo para o subjetivo, de modo que arte poética adquire valor de suprema atividade cognitiva do homem, autotélica e autônoma revoltando-se com a materialização e mecanização da sociedade.

O ato poético, com o advento do Simbolismo, traz em si mesmo sua justificação e tem como missão decifrar o mistério da existência; nas palavras de Mallarmé: "La poésie est l'expression par le langage humain ramené à son rythme essentiel, du sens miysterieux des aspects de l'existance : elle doue ainsi d'authenticité notre sejour et constitue la seule tâche espirituelle"10 .

A poética finissecular debruça-se sobre o interior do homem, na tentativa de auscultar o íntimo desse indivíduo em crise, fustigado pelas correntes dominantes e desiludido com o racionalismo e o cientificismo. O idealismo simbolista, que tem raízes em Kant e Schopenhauer, encontra-se expresso de maneira esclarecedora em Baudelaire no poema "Correspondances" e desenvolve-se como renúncia aos princípios realistas, na medida em que prega a revalorização do mundo subjetivo e metafísico. A realidade visível é apenas aparência da primordial, assim, as correspondências podem ser verticais, entre a representação e a verdadeira realidade, ou horizontais, entre os vários níveis do sentido. Além disso, o "ritmo essencial", ao qual alude Mallarmé, é aspecto muito importante da poesia simbolista e surrealista, porque aponta o desejo de restaurar no homem as suas percepções mais primitivas, ou seja, de aproximá-lo do seu estado natural.

O desconhecido, o indizível, as emoções e os états d'âmes do sujeito não podem ser expressos pela linguagem corrente, por isso, para o Simbolismo, a principal função da

\footnotetext{
${ }^{10}$ MALLARMÉ, Stéphane, La vogue (1886), citado por MICHAUD, Guy, Doctrine Symboliste, Paris, Nizet, 1947, p.15: "A poesia é a expressão, pela linguagem humana reduzida a seu ritmo essencial, do significado misterioso dos aspectos da existência: assim, ela doa autenticidade a nossa jornada e constitui-se a única tarefa espiritual".
} 
linguagem poética é a sugestão. Essa linguagem sugestiva pressupõe certa colaboração artística do leitor num esforço de deciframento e interpretação. Segundo Mallarmé:

Nommer un objet c'est supprimer les trois quarts de la jouissance du poème qui est faite du bonheur de deviner peu à peu; le suggérer, voilà le rêve. C'est le parfait usage de ce mystère qui constitue le symbole: évoquer petit a petit un objet pour montrer une état d'âme, ou, inversement, dégager un état d'âme, par un série dechiffrements. ${ }^{11}$

No poema “Art Poétique”, de Paul Verlaine, também estão expressos elementos programáticos da poética simbolista. O poema parece espécie de conselho aos novos poetas para se alcançar tal linguagem envolvida em mistério, à qual alude Mallarmé:

De la musique avant toute chose, Et pour cela préfère l'Impair

Plus vague et plus soluble dans l'air, San rien en lui pèse ou qui pose.

Il faut aussi que tu n'ailles point Choisir tes mots sans quelques méprise:

Rien de plus cher que la chanson grise

Où l'Indécis au Précis se joint.

C'est des beaux yeux derrière des voiles,

C'est le grand jour tremblant de midi,

C'est, par un ciel d'automne attiédi,

Le bleu fouillis des claires étoiles!

Car nous voulons la Nuance encor,

Pas la couleur, rien que la nuance!

$\mathrm{Oh}$ ! La nuance seule fiance

La rêve au rêve et la flûte au cor!

Fuis plus loin la Pointe assassine,

L'esprit cruel et le Rire impur,

Qui font pleurer les yeux de L'Azur,

Et tout cet ail de basse cuisine!

11 Idem, Enquête (1891), p. 60, citado por MICHAUD, Guy, Doctrine Symboliste, p.74: "Nomear um objeto é suprimir três quartos do gozo do poema que é feito da felicidade de adivinhar pouco a pouco; sugerí-lo, esse é o sonho. É o perfeito uso desse mistério que cosntitue o símbolo: evocar pouco a pouco um objeto para mostrar um estado de alma, ou, inversamente, colocar em evidência um estado de alma, através de uma série de deciframentos". 
Prends l'éloquence et tords-lui son cou!

Tu feras bein, en train d'énergie,

De rendre un peu la Rime assagie.

Si l'on n'y veille, elle ira jusqu'où?

On qui dira les torts de la Rime!

Quel enfant sourd ou quel nègre fou

Nous a forgé ce bijou d'un sou

Qui sonne creux et faux sous la lime?

De la musique encor et toujours!

Que ton vers soit la chose envolée

Qu'on sent qui fuit d'une âme en allé

Vers d'autres cieux à d'autres amours,

Que ton vers soit la bonne aventure

Éparse au vent crispe du matin

Qui va fleurant la menthe et le thym

Et tout le reste est littérature. ${ }^{12}$

O primeiro verso do poema "De la musique avant toute chose", que dialoga com o primeiro verso da penúltima estrofe "De la musique encor et toujours!", evidencia que a música atua como elemento essencial na constituição dessa nova linguagem poética, pois consegue despertar sensações únicas e pode levar a alma a perceber a correspondência entre o material e o espiritual, ou as correspondências no plano dos sentidos. Por isso, os simbolistas buscavam, além de aliterações e assonâncias, novas formas de criar musicalidade nos versos, como o verso ímpar que possibilita alternância na acentuação, e por conseqüência, maior sonoridade.

Outra característica simbolista que avulta nesses versos é a busca pelo vago e pelo impreciso: "Plus vague et plus soluble dans l'air". O vago que se mistura com o ar, como afirma o poeta, aponta para o que não deve ser dito, mas sugerido. O poema abre-se ao leitor com infinitas possibilidades interpretativas; afirma Mallarmé que "un poème est un mystère dont le lecteur doit chercher la clé" ${ }^{13}$. Assim, o velado deve ser valorizado visto

\footnotetext{
${ }^{12}$ VERLAINE, “Art Poétique”, Jadis et Nagùere, p. 19-20.

${ }^{13}$ MALLARMÉ, Stéphane, citado por PEYRE, Henry, Qu'est -ce que le symbolism, Paris, Presses Universitaires de France, 1974, p.109 : "o poema é um mistério do qual o leitor deve procurar a chave"
} 
que conduz o leitor a imaginar o que está atrás dos véus. A opção pelo vago e pelo impreciso faz o poeta, tal qual pintor que usa a meia tinta, desejar não as cores fortes e nítidas, mas a suavidade da nuança, como afirma nestes versos: "Car nous voulons la Nuance encor".

A poética simbolista rejeita tudo o que é reconhecido de imediato em todos os níveis do sentido, olfato, audição, visão e tato, pois se perde o caráter do vago e do sugestivo, negando-se ao leitor a possibilidade de "construir", ele mesmo, o poema. Por isso, de maneira irônica o poeta sugere que se mate por asfixia a eloqüência ("Prends l'éloquence et tords-lui son cou!"), já que ela diz mais do que é preciso. Além disso, o didatismo parnasiano e sua busca pelas rimas perfeitas, pela perfeição formal, tornam o poema superficial; a forma não deve ser desprezada, mas deve estar a serviço do conteúdo, ou seja, ter origem nas camadas significativas do poema. Portanto, mais do que conselho, avulta, no poema, certa paixão pela poesia e pela literatura: o sujeito apaixonado confessa: "Et tout le reste est littérature".

O Simbolismo descobre na sugestão, na associação da poesia com a música, essa sem dúvida sob a influência de Richard Wagner, nas sinestesias, no valor das palavras como imagens irredutíveis a qualquer explicação, a possibilidade de expressar o indizível, a essência do homem. A recusa pela expressão direta dos sentimentos encerra também a revolta dos artistas contra a coisificação da arte. A poesia simbolista, julgada então obscura e hermética, destinada a poucos dispostos a empreender esforços para compreendê-la, traz em si duas características essenciais da poesia moderna: a procura do outro - de um leitor ativo, para preencher os espaços em branco deixados pelo poeta e conferir vida à composição - e a nova posição da arte como resistência a ideologia dominante, na medida 
em que propõe a deformação e recriação do universo segundo paradigmas artísticos, acendendo, ao fim e ao cabo, o desejo no leitor de outra existência, mais livre e mais bela.

A poesia simbolista pretende estabelecer a correspondência entre material e espiritual e também entre interior e exterior. Essas correspondências, que se fazem por meio de sensações, nada mais são que leituras pessoais dos chamamentos emitidos pela realidade exterior. De fato, as sensações, por si mesmas, pouco interessam, da mesma forma que o mundo exterior pouco representa isoladamente; os dois níveis precisam estar em correspondência. Portanto, as imagens têm extrema importância, não para reproduzir a realidade tal qual, nem para comunicar apenas as sensações, mas pelo fato de que, através delas, o poeta oferece ao leitor as correspondências entre interior e exterior.

Essa rebelião poética de negação do racionalismo, da matéria e da ciência desenvolve-se de maneira profícua na França, ou melhor, na cidade de Paris, capital da nação do espírito discursivo e cartesiano de análise. O Simbolismo - embora sua origem remonte ao místico sueco Emmanuel Swendenborg, como reitera Anna Balakian - foi parisiense e cosmopolita, desenvolvendo-se com muitas pluralidades e prenunciando as vanguardas européias seguintes.

A perspectiva pluralista do movimento e sua falta de homogeneidade permitiram a incorporação das identidades culturais próprias promovendo a interculturalidade do Simbolismo. Assim, sem dúvida, o Simbolismo português nasce em diálogo com o francês, introduzindo, entretanto, especificidades próprias da nação portuguesa. Nos dois países, a nova literatura começa a fermentar a partir da reunião nos cabarés, da revitalização da boêmia artística, ambiente propício para o desenvolvimento de revistas. Na França, o movimento começa a tomar força com a publicação das revistas Lutèce, Nouvelle Rive Gauche, Hydrophathes. Em Portugal, o Simbolismo emerge com publicação de duas 
revistas, Os Insubmissos e Boémia Nova, que trazem as inovações temáticas e estéticoformais e a polêmica em torno da cesura do alexandrino.

O Simbolismo Francês desenvolve-se apoiado na revolução poética operada pela tríade Mallarmé, Verlaine e Rimbaud. Embora esses autores, como afirmam muitos críticos, estejam fora cronologicamente do movimento, visto que escreveram e publicaram antes do Simbolismo francês propriamente dito, que tem início oficialmente em 1886, com a publicação de Manifeste du Symbolisme de Jéan Moréas, eles são os grandes expoentes dessa poética em França.

Mallarmé, apesar de ter escrito pouco, foi eleito mestre, pois influenciou muitos jovens simbolistas com seu ocultismo, sua alquimia verbal, com a destruição da sintaxe da língua francesa, enfim, com sua busca obsessiva pelo Belo, a qual Guy Michaud denomina “maladie d'idealité" e da qual a poesia, segundo o próprio poeta, é a única expressão: "Il n’y a que la Beauté, et elle n'a qu'une expression - la Poésie". ${ }^{14}$ Assim, devido a tal elevação da poesia, a realidade deveria ser recriada segundo parâmetros estéticos e artísticos e a criação artística do poeta por meio do processo simbólico substituiria a feita por Deus. A idéia de Mallarmé, mais do que filosofia metafísica, é estética, ou, ainda mais que filosofia, constitui-se como espécie de religião da poesia.

Enquanto na poesia de Mallarmé o desconhecido é o Belo e o Absoluto, que se mostram por meio do fazer poético, em Rimbaud, a busca concentra-se na exploração do que se encontra escondido nas profundezas da consciência ou da inconsciência. Em seus poemas, tudo parece vertiginoso delírio e devaneio, estados que devem ser provocados: "se

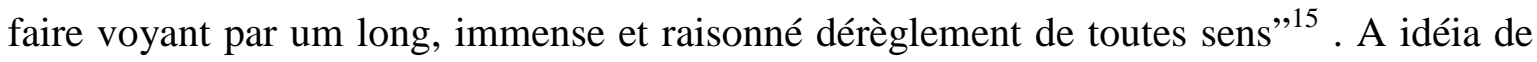
visionário surge no Romantismo, sobretudo se pensarmos em Victor Hugo; para ele,

\footnotetext{
${ }^{14}$ Idem, Lettre à Cozalis (1867), citado por MICHAUD, Message Poétique du Symbolisme, p. 32 : "Há somente a Beleza, e ela só possui uma expressão: a Poesia".

${ }^{15}$ RIMBAUD, Arthur, citado por PEYRE, Henri, Op. cit., 1974, p.55: "se fazer visionário por meio de uma longa, imensa e racional perturbação de todos os sentidos".
} 
visionário, em "Fonction du poète" e "Les Mages", é o sujeito que consegue enxergar o futuro, que enxerga além dos outros. No entanto, para Rimbaud, o poeta deve ser visionário não no sentido de enxergar o futuro, mas de enxergar o seu mundo interior, ou seja, seu inconsciente, no qual os sentidos são livres e as imagens afloram como alucinações. Sobre esse mundo interior o poeta não tem controle, por isso, afirma “je est un autre" (eu sou outro); assim, tornar-se visionário é descobrir esse outro. A noção de inconsciente e de estado onírico nos poemas de Rimbaud foi retomada e desenvolvida, anos mais tarde, pelo Surrealismo.

Já Paul Verlaine foi o poeta que mais escreveu se comparado aos outros dois simbolistas franceses. Sua poesia é desprovida de grandes pretensões filosóficas e metafísicas como a de Mallarmé e também não tem o lirismo agressivo de Rimbaud, concentrando-se na sensação, seja essa visual, táctil, olfativa, mas, sobretudo, musical, como comprovamos no seu poema "Art Poétique". A musicalidade dos seus poemas salta aos olhos, o que o fez muitas vezes ser nomeado de "poeta músico". Com seus versos ímpares, seus encadeamentos ousados, seus prosaísmos e suas expressões familiares, Verlaine ajudou a renovar a clássica poesia francesa.

A musicalidade de Verlaine liga-se ao movimento lento, ao caráter fugidio e fugaz das paisagens; imagens de árvores, nuvens, moinhos e fantasmas passam diante dos seus olhos e também do leitor como fugidias visões. Seus poemas são muitas vezes a contemplação do sujeito poético da sensação que está muito próxima de se extinguir; na verdade, ele sente que o mundo está desaparecendo, que tudo é inapreensível, restando apenas esse traço evanescente das sensações. A imagem da folha morta levada pelo vento, poetizada em um de seus poemas, é símbolo da atitude do sujeito poético inserido na poesia de Verlaine e também é imagem recorrente na poética simbolista. O Eu é alguém sem forças, indiferente, langoroso, que se deixa levar pelas forças externas: 
Et je m'en vais

Au vent mauvais

Qui m'emporte

Deçà, dela,

Pareil à la

Feuille morte. ${ }^{16}$

Esse sentimento de passividade e apatia deve-se à crise do questionamento do modelo de racionalismo científico, mas, além disso, às expectativas da Europa em geral, desenvolvidas às voltas do final do século, segundo as quais a humanidade poderia caminhar-se para uma catástrofe. Sem dúvida, o sentimento de declínio e decadência é anterior ao movimento simbolista - como pode ser evidenciado pelos poemas de Baudelaire e Cesário - e refere-se não somente a algumas áreas da existência humana, mas é sentido por toda Europa ocidental como circunstância histórica. O desencanto não é apenas em relação a um quotidiano específico de uma sociedade industrial, mas conjuga-se com uma espécie de desgosto íntimo diante dos valores coetâneos, ou ainda, com a angústia diante de uma vida que não tem mais sentido. Desse pesar é cunhada a expressão fin-de-siècle que reflete não só o mal-estar social, mas também ôntico. O "des-encanto" do homem é traduzido pelas imagens de fim, de aniquilamento, de queda, pelas imagens de objetos e/ou fenômenos naturais que se encaminham para seu término, de desintegração do eu e aniquilamento pessoal.

Apoiado nesse sentimento de Mal-estar generalizado, desenvolve-se em França o Decadentismo, cujo principal representante é Jules Laforgue. Essa poética, que surge antes do Simbolismo, tem pontos em comum com o movimento simbolista; no entanto, despreza alguns princípios simbolistas propriamente ditos, como a busca pelo Belo, o culto ao esteticismo e a primazia da música. Os decadentistas buscam, no meio externo, elementos

\footnotetext{
${ }^{16}$ VERLAINE, Paul. Chanson d'Automne. Poème Saturniens, Oeuvres Poétiques Completes, Paris, Gallimard - Pléiade, 1948, p. 34.
} 
que descrevam seu estado de alma, ou seja, o reflexo da decadência íntima apresentado em imagens de degenerescência física do homem, em patologias e nevroses, além de extremo pessimismo, aniquilação e certa obsessão pelo paroxismo da existência.

De fato, muitos poetas que escreveram nesse final de Oitocentos, ainda que não pertençam ao Decadentismo enquanto poética, expressam, nas suas obras, a noção de decadência, já que o tema do desânimo, da apatia, do enfraquecimento, enfim, do cansaço e também desencanto pelo excesso de cultura e técnica, pela vida materializada, pela sociedade injusta, pela moral burguesa avultam em muitos poemas. Tais sentimentos não se restringem a somente uma cultura ou nação, mas se estendem a toda arte desse período, como afirma o poeta Luiz de Montalvôr na revista portuguesa do início do século XX,

\section{Centauro:}

Somos mais sentidamente decadentes porque somos mais misticamente doentes que todos os místicos de todas as doenças espirituais de todos os tempos. A decadência é para nós o símbolo com que vestimos o estado de alma coletivo de exilados da Beleza! Ser-se decadente é ser-se doente espiritualmente, é ser-se superior! A arte é a doença imortal dos pálidos de Deus e da Beleza... ${ }^{17}$

Portanto, a decadência que é coletiva, não é moral, mas como afirma o poeta, é espiritual, de modo que evidencia o estado de espírito tomado pelo ennui excessivo, pela aguda sensibilidade, pela frustração com as coisas que, por conseguinte, reduz a vida à inação. Segundo a crítica Anna Balakian, "o que impede o decadente de se tornar uma figura neurastênica e patológica é que o escritor decadente projeta sua atitude sobre a arte (...) dirige o culto do ego para um símbolo exterior que sua mente é capaz de transformar

\footnotetext{
${ }^{17}$ MONTALVÔR, Luiz de, Tentativa de um ensaio sobre a decadência, Centauro, Edição Facsimilada. Lisboa, Editora Contexto, 1982, p.8.
} 
em objeto de Beleza" ${ }^{18}$. Esse modelo do Decadentismo é dado pelo Duque Des Esseintes de A Rebours, de Hyusmans.

Embora Verlaine não seja propriamente decadentista, o sentimento de decadência, reflexo do mal estar do homem no final do século XIX, é comum em sua poesia. Esse pesar, expresso de maneira precisa no soneto "Langueur", publicado na revista Chat Noir, foi responsável por inspirar o movimento:

Je suis l'empire à la fin de la décadence,

Qui regarde passer les grands Barbares blancs

En composant des acrostiches indolents

D'un style d'or où la langueur du soleil danse.

L'âme suellete a mal au coeur d'un ennui dense.

Là-bas on dit qu'il est des longs combats sanglants.

O n'y pouvoir, étant si faible aux voeux si lents,

O n'y vouloir fleurir un peu cette existence!

O n'y vouloir, ô n'y pouvoir mourrir un peu!

$\mathrm{Ah}$ ! tout est bu! Bathylle, as-tu fini de rire?

$\mathrm{Ah}$ ! tout est bu, tout est mangé! Plus rien à dire.

Seul, un poème un peu niais, qu'on jette au feu,

Seul, un esclave un peu coureur qui vous néglige,

Seul, un ennui d'on ne sait quoi qui vous afflige! ${ }^{19}$

A metáfora da decadência do império serve para exprimir todo o Mal-estar do sujeito. A imagem do império no primeiro verso evoca a situação da França no final do século XIX, que também contribui para o desenvolvimento do Decadentismo. O fracasso das esperanças revolucionárias, a derrota na guerra franco-prussiana e a queda do Segundo Império, de Napoleão III, colaboraram para a criação do clima coletivo de decadência.

Se na França existiam duas poéticas distintas, o Simbolismo e o Decadentismo, em Portugal, ambas estão juntas, ou seja, houve uma só poética: o Simbolismo, formado

\footnotetext{
${ }^{18}$ BALAKIAN, Anna, O Simbolismo, São Paulo, Ed. Perspectiva, 1995, p. 68.

${ }^{19}$ VERLAINE, «Langueur », Jadis et Naguère, p. 83.
} 
autores que foram só simbolistas ou por simbolistas-decadentistas - como é o caso, segundo Óscar Lopes, de António Nobre, António Patrício e Raul Brandão. Portanto, o Decadentismo não se constitui como uma poética em Portugal, mas quase como uma proposta filosófica que embasa o Simbolismo.

Embora o Decadentismo não tenha se configurado como poética, o sentimento de abatimento contaminava tudo e todos em Portugal. O sentimento de decadência, sentido em toda Europa, em Portugal, assume particularidades e se faz sentir de maneira intensa, pois, além das circunstâncias européias do fim do século, o país atravessava uma época de declínio político, econômico e cultural. A situação de decadência de Portugal em relação à Europa já é abordada pela Geração de 70, sobretudo por Oliveira Martins em História de Portugal e Antero de Quental em Causas da Decadência dos Povos Peninsulares Portugueses, que discutia as causas da posição da na nação portuguesa e a relação do Portugal do passado com o do presente, preocupando-se não apenas na retomada do passado, mas no desenvolvimento do futuro Portugal, inserido no quadro europeu de modernidade.

O Ultimatum inglês de 1980, episódio em que o governo britânico entrega em 11 de Janeiro de 1890 um "Memorando" - a Portugal, para a retirada das forças militares existentes na zona territorial compreendido entre as colónias de Moçambique e Angola. O território reivindicado por Portugal, que a havia incluído no famoso Mapa cor-de-rosa, foi reclamando na Conferência de Berlim. O episódio acentua ainda mais a situação de decadência da nação Portuguesa é recebido por Portugal como hecatombe nacional, expresso tão bem nas palavras de Maria Teresa Pinto Coelho como "o derradeiro sopro de vida de uma nação agonizante, que atinge finalmente o término de sua existência". ${ }^{20}$ As terras africanas representavam para Portugal não somente a possibilidade de melhora

\footnotetext{
${ }^{20}$ COELHO, Maria Teresa Pinto, Apocalipse e regeneração: o Ultimatum e a mitologia da Pátria na literatura finissecular, Lisboa, Edições Cosmos, 1996, p.17.
} 
econômica e política, mas a esperança da volta mitológica do império português, cujo passado glorioso poderia ser revivido por meio da exploração do território africano; assim, o Ultimatum inglês, além de terrível golpe na auto-estima portuguesa, derrubou por terra o sonho imperial português e, por isso, é sentido pela nação como verdadeira catástrofe apocalíptica.

A decadência pátria aparece em muitos poemas de António Nobre associada à degenerescência pessoal do sujeito. O passado glorioso de Portugal é associado ao período da infância do sujeito. O sentimento de decadência geral, mas também particularmente português, devido às circunstancias específicas do país, é evidente neste poema de Nobre:

\footnotetext{
Em certo Reino, á esquina do Planeta, Onde nasceram meus Avós, meus Paes, Há quatro lustres, viu a luz um poeta Que melhor fora não a ver jamais.

Mal despontava para a vida inquieta, Logo ao nascer, mataram-lhe os ideaes, Á falsa-fé, n'uma traição abjecta, Como os bandidos nas estradas reaes!

E, embora eu seja descendente, um ramo D'essa arvore de Heroes que, entre perigos E guerras, se esforçaram pelo Ideal:

Nada me importas, Paiz! Seja meu Amo Carlos ou o Zé da Th'ereza...Amigos, Que desgraça nascer em Portugal! $!^{21}$
}

A experiência individual do sujeito poético, visto que ele rememora sua infância, ou ainda sua descendência ilustre de heróis, emaranha-se a experiência coletiva; ao recobrar sua infância o sujeito poético recupera a de seu povo, isto é, o tempo glorioso da nação imperial, que se contrapõe ao presente de ruínas de Portugal. A construção do individual em Nobre está ligada à construção do coletivo, ou seja, o sujeito é a representação do nacional; assim, a todo o momento, a história pessoal do sujeito poético e a da pátria se

\footnotetext{
${ }^{21}$ NOBRE, António, Soneto 2, Só. $5^{\text {a }}$ ed. Porto, Araújo \& Sobrinho, 1931, p. 144.
} 
entrelaçam. De fato, o indivíduo se constitui como imagem do nacional, pois da mesma forma que ele teve uma infância feliz, seu país também viveu uma época de ouro e agora se encontra desencantado com o presente. Portanto, a poesia de Nobre une os dois destinos, o do indivíduo e o da pátria, na medida em que os dois experimentaram a Idade de Ouro cair por terra e encontram-se agora num presente que é decepcionante. Esse sentimento de Malestar provocado pelo presente português, pela decadência, é expresso de maneira contundente no último verso do poema, no qual o sujeito afirma:

Que desgraça nascer em Portugal!....

A poética decadentista-simbolista no Só assume particularidades: a mística ocultista dos decadentes franceses é substituída por crendices populares portuguesas, por certo catolicismo supersticioso e folclórico do povo português, esse identificado com os pescadores e camponeses. Além disso, Nobre insere elementos da coloquialidade e expressões populares que fazem dele um simbolista singular, com uma poesia também especial que se aproxima do Modernismo, na medida em que no Só avultam elementos de modernidade - como a musicalidade advinda do modo de falar popular, das expressões coloquiais ("si o barco fôri interiro", "zutt", “mail-a") - que parecem afastar o poeta do Simbolismo francês, já que tornam a sua poesia menos aristocrática e mais próxima do cotidiano.

Em alguns poemas de Clepsidra, o sentimento de decadência da nação portuguesa também aparece relacionado à degradação íntima do eu. Em Pessanha o destino do sujeito poético não pode ser totalmente identificado de forma tão marcada com o da nação, como vimos em Nobre. No díptico de poemas "San Gabriel” a decadência pessoal é vista como 
parte da coletiva; o "nós" é integrador, portanto, por essa via vê-se também a decadência do eu. Leiamos as composições:

\section{I}

Inútil! Calmaria. Já colheram

As vellas. As bandeiras socegaram

Que tão altas nos topes tremularam,

- Gaivotas que a voar desfalleceram.

Pararam de remar! Emmudeceram! (Velhos rihtmos que as ondas embalaram).

Que cilada que os ventos nos armaram!

A que foi que tão longe nos trouxeram?

São Gabriel, archanjo tutelar,

Vem outra vez abençoar o mar,

Vem-nos guiar sobre a planície azul

Vem-nos levar á conquista final

Da luz, do Bem, doce clarão irreal.

Olhae! Parece o Cruzeiro do Sul!

\section{II}

Vem conduzir as naus, as caravellas, Outra vez, pela noite, na ardentia,

Avivada das quilhas. Dir-se-ia

Irmos arando em um montão de estrellas.

Outra vez vamos! Côncavas as vellas,

Cuja brancura, rútila de dia,

O luar dulcifica. Feeria

Do luar não deixes de envolve-las!

San Gabriel, vem-nos guiar á nebulosa Que do horisonte vapora, luminosa,

$\mathrm{E}$ a noite lactescendo, onde quietas,

Fulgem as velhas almas namoradas...

- Almas tristes, severas, resignadas,

De guerreiros, de santos, de poetas. ${ }^{22}$

Os dois poemas são singulares no conjunto da obra de Pessanha, por um lado, por fazerem sobressair a voz coletiva e um "nós" em oposição às inúmeras referências ao eu

\footnotetext{
${ }^{22}$ PESSANHA, Op. cit, pp 25-26.
} 
individual da maior parte das composições de Clepsidra e, por outro lado, pela evidência ainda que sutil de certa "vontade" como tentativa de sair da situação de crise, expressa na invocação de São Gabriel.

Não por acaso, os poemas tratam de barcos no mar, que são, sem dúvida, metáforas do indivíduo ou de toda uma nação, os quais são como pequenas e frágeis embarcações, sem controle sobre sua vida e destino, sujeitos às inconstâncias da vida e do tempo, idéia expressa no poema pelas "ciladas que os ventos armaram". Além disso, a imagem também denota a importância do mar na cultura portuguesa, já que Portugal é nação marítima e o mar é o meio pelo qual Portugal conseguiu ser imperial. Dessa maneira, os poemas evocam o período das navegações portuguesas, séculos XV e XVI, num sentido que é também o de configurar o ser português.

No primeiro poema, aparece o ânimo abatido de um povo e do Eu inserido nele, ambos encontram-se no final de um processo, pois as velas já foram colhidas, as bandeiras já sossegaram e as gaivotas já desfaleceram; essas são imagens que podem simbolizar as atividades de um país, bem como de sonhos e esperanças que esmoreceram. Por isso, o poema termina com a invocação de São Gabriel para que, assim como no passado, o povo possa reanimar-se. A decadência é tamanha que somente com o auxílio de forças sobrenaturais talvez seja possível conquistar o Bem, ou seja, as grandezas perdidas. Além disso, São Gabriel é justamente o nome de uma das naus que compunham a esquadra com que Vasco da Gama chegou à Índia. Ainda: São Gabriel é o anjo da Anunciação - é ele que anuncia a Maria que ela está grávida do Salvador.

A invocação de São Gabriel na tentativa de voltar à glória do passado continua na segunda composição. No entanto, já aparece a consciência dolorosa de um indivíduo que sabe ser impossível tal feito, uma vez que o passado não pode ser reconstruído, apenas sugerido por meio de traços mínimos, pois se encontra depositado na memória, coletiva ou 
individual, envolto em nebulosas lembranças. De fato, o passado feliz e glorioso da nação e também o do sujeito, ambos evocados pelos arquétipos de guerreiros, santos e poetas que se apresentam como "almas tristes, severas, resignadas" não pode retornar, limitando-se a residir na memória.

Ainda que a temática decadentista esteja presente nos poemas de Pessanha, como por exemplo, o paroxismo da existência, a apatia, o desânimo, eles superam o Decadentismo enquanto poética; sua poesia impõe-se como simbolista devido a razões estruturais, na medida em que desenvolve elementos estilístico-formais próprios do Simbolismo. Para muitos críticos do movimento, como Seabra Pereira e Óscar Lopes, Camilo Pessanha é o representante mais "puro" do Simbolismo em Portugal, sobretudo se pensarmos naquele de raiz francesa. Segundo Seabra Pereira:

Uma ampla realização do Simbolismo só poderá ser buscada em Camilo Pessanha, descobrindo na Clepsidra um singular fenômeno adentro do jogo dialético "conteúdo/forma"; ao contrário do que se verifica nos assomos supra-decadentistas dos outros poetas, em Pessanha como se desenvolve o seguinte esquema (forçosamente simplista): uma "mensagem" originária e prevalecentemente decadentista toma o passo de uma "expressão" mais avançada e que parcialmente a redimensiona - a depura, a subtiliza ou a supera - num sentido simbolista. ${ }^{23}$

Os três grandes nomes do Simbolismo Português representam três linhas dessa poética: Eugênio de Castro, cuja obra Oaristos foi responsável pela inauguração oficial do movimento em Portugal, ilustra em sua poesia intensa experimentação verbal, perseguindo de maneira exacerbada os elementos formais que representavam a inovação dessa escola. Tais elementos formais são construídos com tal artificialidade que, ao fim e ao cabo, acabam por desenvolver o que podemos chamar de "simbolismo parnasiano". António

\footnotetext{
${ }^{23}$ PEREIRA, José Carlos Seabra, Decadentismo e Simbolismo na Poesia Portuguesa, Coimbra, Centro de
} estudos Românicos, 1975, p. 457. 
Nobre, com a inserção de elementos populares e da coloquialidade em suas composições, afasta-se do Simbolismo francês e antecipa os aspectos que serão desenvolvidos pelo Modernismo; Camilo Pessanha, muitas vezes denominado de "Verlaine português", sobretudo devido ao uso que faz das estruturas formais, que conferem musicalidade aos poemas, é tido como herdeiro do Simbolismo francês e como o único simbolista evidentemente grande em Portugal.

\subsection{A experiência moderna do Tempo na poesia Simbolista}

No Simbolismo, enquanto poética da Modernidade, a representação íntima do Eu torna-se cada vez mais presente nos poemas. Nesse contexto, o tema do Tempo e do sujeito em crise diante da realidade desenvolve-se de maneira singular, pois se liga a representação dos sentimentos mais íntimos do sujeito poético.

A consciência da sua situação de decadência, do seu desajuste diante das modificações provoca o recolhimento íntimo, como já bem observamos nos poemas de Baudelaire e Cesário. Devido ao mal-estar experimentado pelo indivíduo, ao tédio, ao desencanto, ao sentimento de estar à margem das inovações e do seu tempo, o sujeito recolhe-se em si mesmo, mergulhando em outra realidade, outro espaço e outro tempo, absolutamente subjetivados.

O tema do fluir inexorável do tempo sempre esteve presente na literatura, contudo, é no final do século XIX que se configura como obsessão. É nesse mesmo século que se presencia a expansão na produção e no uso dos relógios, além disso, no campo da indústria começa-se a medir a duração da execução das tarefas para estabelecer normas e rendimento que irão culminar no taylorismo; enfim modificações sociais que criam uma sociedade dominada pelo tempo mensurável. A vida torna-se regida por convenções de 
tempo, minutos, horas, dias e anos criando certo condicionamento artificial da existência que toma ares de natural, pois já se constitui como processo psicológico interiorizado. Assim, a técnica moderna introduz na atitude perante a vida um dinamismo sem precedentes e para o homem moderno, como afirma Hauser, “A experiência do mundo é cada vez mais a experiência do tempo". ${ }^{24}$ Não por acaso, a partir do final do século XIX, a arte busca captar o vago e o transitório, as emoções fugidias e os estados de alma.

O tema do tempo e do sujeito desencantado, na poesia simbolista, mostra-se como espécie de topos, como um elemento-chave do movimento. Baudelaire, em Les Fleurs Du Mal compõe um poema que se intitula “L'Horloge":

Horloge! dieu sinistre, effrayant, impassible,

Dont le doit nous menace et nos dit: Souviens-toi!

Les vibrantes Douleurs dans ton coeur plein d'effroi

Se planteront bientôt comme dans un cible; ${ }^{25}$

Os versos de Baudelaire ilustram a presença do relógio que na sociedade finissecular torna-se elemento fundamental. Nesse poema baudelairiano, ele emerge como representação concreta da passagem do tempo, por isso, é qualificado como sinistro, amedrontador e impassível, já que tem a função de recordar a fugacidade da vida e a tragicidade da existência.

Segundo Seabra Pereira, a questão do Tempo, na poesia simbolista, liga-se a inúmeras sensações do sujeito poético:

A significação psicológico moral deste pensar o Tempo vai se revelando progressivamente e desdobra-se em vários aspectos. É no tempo que se dá a transformação contínua do eu (...), e é ele que determina as inconstâncias das realidades exteriores e do destino (..), é o

\footnotetext{
${ }^{24}$ HAUSER, Arnold. Impressionismo, História Social da Arte e da Literatura, São Paulo, Ed. Martins Fontes, 1995, pp. 894-955.

${ }^{25}$ BAUDELAIRE, «L'Horloge », Op. cit, p. 76.
} 
Tempo que se alonga em tédio, lamentam muitos poetas, mas é ele também que gera o desgosto irreprimível pela perda dos anos(...) É no envolver cronológico que se dá, como tantos experimentam, a queda do engano ao desengano e a decadência. ${ }^{26}$

De fato, na lírica finissecular a consciência medieval da tragicidade na passagem do Tempo soma-se ao condicionamento moderno da experiência do Tempo, ou seja, a transformação contínua do homem e da sociedade, a instabilidade do real, a fugacidade das coisas, enfim, o tédio proporcionado pelo desajuste do tempo interior do sujeito com seu tempo exterior.

Introduzida a poética simbolista, os capítulos seguintes tratam do tema do Tempo e do sujeito em crise recolhido em si mesmo, bem como das questões estilístico-formais do Simbolismo, particularmente nos poemas de Paul Verlaine e Camilo Pessanha. De acordo, com Eliot: "Nenhum poeta, nenhum artista tem sua significação completa sozinho (...) é preciso situá-lo para contraste e comparação" ${ }^{27}$; assim, esse diálogo torna-se interessante na verificação de mais do que influências, de convergências dessas idéias poéticas e filosóficas inseridas nesse contexto finissecular.

\footnotetext{
${ }^{26}$ PEREIRA, Op. cit, p. 286.

${ }^{27}$ ELIOT,T. S., Ensaios, Tradição e Talento Individual, (trad. Ivan Junqueira), Rio de Janeiro, Art Editora, 1989, p. 39.
} 


\section{CAPÍTULO II - PAUL VERLAINE}

Nas obras Poèmes Saturniens e Jadis et Naguère, a relação do eu com o tempo não é tão marcante e explícita como em Clepsidra, conforme veremos adiante, e aparece muitas vezes, como observaremos nos poemas escolhidos, conjugada com o impressionismo particular de Verlaine. Afirma o crítico Henri Peyre:

Plusieurs poèmes de Verlaine sont impressionistes encore, mais composés plutôt que juxtaposés et incorporant en eux l'element dramatique du temps qui s'enfuit et qui revet les impressions du présent de la nostalgie du passé, de l'angoisse devant l'avenir. ${ }^{28}$

A atmosfera pictural característica da poesia de Verlaine liga-se à musical a fim de exprimir a angústia provocada pela realidade fugidia das coisas, ou seja, as paisagens evanescentes amalgamam-se com o ritmo fluido de seus poemas. O impressionismo de Verlaine difere-se daquele desenvolvido pelos pintores, pois o poeta não é um colorista, mas apóia-se em descrições vagas, como ele mesmo afirmou em "Art poétique":

Car nous voulons La nuance encor

Pas la couleur, rien que la nuance. ${ }^{29}$

Sem dúvida, essa poesia pictórica, que retrata paisagens fugidias e vagas, nasce da convergência das tendências artísticas do final do século XIX:

A pintura impressionista descobre sensações que a poesia e a música tentam também exprimir e os seus meios de expressão se adaptam assim, às formas da pintura. As impressões de atmosfera, em particular a

\footnotetext{
${ }^{28}$ PEYRE, Op. cit, p. 9: "Ainda que vários poemas de Verlaine sejam impressionistas, eles são compostos mais que justapostos, incorporando neles o elemento dramático do tempo que foge e que reveste as impressões do presente, da nostalgia do passado, da angústia diante do futuro.

${ }^{29}$ VERLAINE, « Art Poétique », in Jadis et Naguère, p. 19.
} 
experiência de luz e cor, são percepções próprias da pintura, e quando se tenta reproduzir noutras artes impressões desta espécie é perfeitamente legítimo falar de um espírito pictório da poesia e da música. Mas o estilo destas artes é também pictório quando se exprime renunciando a precisar "contornos", à custa de efeitos de cor e sombra, e dando mais importância a vivacidade dos pormenores do que a uniformidade da impressão total ${ }^{30}$.

As duas obras de Paul Verlaine, Poèmes Saturniens e Jadis et Naguère, inseremse nessa perspectiva impressionista, pois buscam, mais que descrever o ambiente, sugerir impressões. Pululam atmosferas vagas e imprecisas: paisagens evanescentes, brumas, crepúsculos, sons plangentes, que atuam na construção do sujeito poético na medida em que sugerem seu état d'âme .

Tendo em vista tal opção temático-formal das duas obras verlainianas, é possível colocá-las lado a lado, entretanto, faz-se necessário também considerar a distância entre elas. Primeiro, a distância temporal, quase vinte anos separam as duas obras: Poèmes Saturniens, primeiro livro de Verlaine, foi escrito, segundo o poeta, aos seus dezesseis anos, quando ainda estava no liceu, em 1866; já Jadis et Naguère aparece somente em 1883.

Muitos críticos inserem a primeira obra de Verlaine no Parnasianismo, devido aos poemas conterem ainda um eco parnasiano, que se evidencia, sobretudo, pela impassibilidade, pelo gosto do mármore e pela presença de Gautier e Leconte de Lisle. No entanto, em arte, a rotulação das obras é sempre complicada e discutível, pois, como aponta Guy Michaud, encontra-se, em Poèmes Saturniens, estética parecida com a usada por Baudelaire em Tableaux Parisiens, de modo que, se existe certo parnasianismo, esse se descobre impregnado de Baudelaire e os poemas, segundo o crítico, podem ser chamados de "poèmes baudelairiens". Assim, se é possível perceber o eco parnasiano nos poemas, a voz simbolista também pode ser ouvida.

\footnotetext{
${ }^{30}$ HAUSER, Op. cit, p. 1056.
} 
Sem juízo de valor, mas pensando somente nos procedimentos estético-formais do Simbolismo, podemos estabelecer progressão entre as obras, visto que em Poèmes Saturniens verifica-se certos procedimentos simbolistas que ainda estão em estado embrionário e que serão desenvolvidos de maneira inovadora em Jadis et Naguère.

O estado de espírito decadente, característico da poesia finissecular, aparece muitas vezes ligado à melancolia em poemas da obra de Verlaine. Já no título de Poèmes Saturniens, a melancolia faz-se presente, visto que Saturno, pela lentidão no seu movimento de rotação é considerado pela astrologia o planeta dos melancólicos. Na dedicatória tem-se a noção de que os sofrimentos do sujeito estão associados a uma influência maligna, ou seja, ao fato de ter nascido sob o signo de Saturno, que se identifica também com o exercício da poesia, pois, como anteriormente evidenciado em Baudelaire e Cesário, ser poeta é ser diferente e, mais do que isso, é ser maldito. Dessa maneira, Poèmes Saturniens inicia-se com tais versos:

Or ceux-là qui sont nés sous le signe de SATURNE,

Fauve planète, chère aux nécromanciens

Ont entre tous, d'après les grimoires anciens,

Bonne part de malheur et bonne part de bile.

L'Imagination, inquiète et débile,

Vient rendre nul en eux l'effort de la Raison.

Dans leurs veines le sang, subtil comme un poison,

Brûlant comme une lave, et rare, coule et roule

En grésillant leur triste Idéal qui s'écroule.

Tels les Saturniens doivent souffir et tels

Mourir, - en admettant que nous soyons mortels, -

Leur plan de vie étant dessiné ligne à ligne

Par la logique d'une influence maligne ${ }^{31}$

Esse sentimento de melancolia que aparece na dedicatória, ligado a influência nefasta de Saturno, desdobra-se em quase todos os poemas. No primeiro conjunto de composições do livro, Melancholia, os poemas evocam, nos seus próprios títulos,

\footnotetext{
${ }^{31}$ VERLAINE, Poèmes Saturniens, p. 56-57.
} 
sentimentos ligados ao estado de espírito melancólico, como por exemplo, "Resignation", “Lassitude” e "L’Angoisse”. Seguido de Melancholia, encontra-se Paysages Tristes, grupo de poemas que se constituem, ao fim e ao cabo, como paisagens de melancolia.

Na verdade, nas composições de Poèmes Saturniens, na tentativa de definir o état d'âme do sujeito poético, misturam-se sentimentos de tristeza, de angústia, de langor, de resignação, enfim, de melancolia. Esse último apresenta-se como a modernização do mal de vivre romântico, liga-se ao desencanto do sujeito com a realidade circundante, fazendoo mergulhar, muitas vezes, em extrema abulia, cuja última conseqüência é o desejo de deixar de existir, ao menos nesse mundo de desgosto e desilusão. Por isso, de acordo com Michaud, o sujeito poético de Poèmes Saturniens caraceriza-se pela «mélancolie compliqué d'un jouisseur lassé malade, qui se sent glisser avec l'efroi et plaisir à la fois, sous les pouvoir d’influences nefastes, vers des heures noires $»^{32}$

No Romantismo, para definir a insatisfação do eu com o mundo e consigo mesmo, evocada por estados de espírito como tédio, nostalgia e tristeza, surge a palavra inglesa spleen, que significa baço. $\mathrm{Na}$ Antiguidade, os gregos tratavam a melancolia como patologia; Hypócrates criou no campo da medicina a famosa doutrina dos humores, associando o temperamento melancólico com o baço, sede do humor negro, pois era nesse órgão que, segundo ele, produzia-se a bílis negra. Esse mecanismo físiológico seria o responsável pelo desânimo e tédio. A idéia grega está presente na dedicatória de Poèmes Saturniens, na qual o sujeito poético afirma que sua condição sofrível vem de ter correndo nas veias a bile negra: "Bonne part de malheur et bonne part de bile."

Tendo em vista essa existência sofrível que o sujeito não tem forças para transformar, já que sua vida está sob influência maligna de Saturno ("Leur plan de vie étant

\footnotetext{
${ }^{32}$ MICHAUD , Message poétique du Symbolisme, p. 107 : "melancolia complicada de um gozador que tornou-se doente, que se sente escorregar, ao mesmo tempo, com pavor e prazer, sobre os poderes de influências nefastas, em direção a horas negras".
} 
dessiné ligne à ligne/ Par la logique d'une influence maligne"), percebemos, muitas vezes, nos poemas, o anseio de deixar de sentir e de existir, tema que é também marcante no poema "Chanson d'Automne". Como se vê abaixo, essa vontade é ilustrada pela folha morta levada, impassível, pelo vento:

\section{Chanson d'Automne}

Les sanglots longs

Des violons

De l'automne

Blessent mon coeur

D'une langueur

Monotone.

Tout suffocant

Et blême, quand

Sonne l'heure,

Je me souviens

Des jours anciens

Et je pleure;

Et je m'en vais

Au vent mauvais

Qui m'emporte

Deçà, dela,

Pareil à la

Feuille morte. ${ }^{33}$

O estado de espírito decadentista, as impressões fugidias, a musicalidade, a predileção por certos temas como o outono e o poente, características do Simbolismo, apresentam-se de maneira singular em "Chanson d'Automne" e criam espécie de quadro impressionista. Essa composição encontra-se no conjunto de poemas denominado Paysages Tristes, título singular, pois a tristeza não pode ser característica como algo externo, de paisagens, mas é sentimento do sujeito poético que, por estar triste, percebe tudo com tristeza; é a emoção íntima do indivíduo que contamina o ambiente.

\footnotetext{
${ }^{33}$ VERLAINE, “Chanson D’ Automne”, Poèmes Saturniens, p. 34.
} 
O título "Chanson d'Automne" traz duas idéias importantes do movimento simbolista: por um lado, o desejo de tornar o verso o mais musical possível, evocado pela canção (“chanson”), por outro, as imagens ou paisagens que estão próximas da extinção, sugeridas pelo outono ("automne"). Esses dois elementos simbolistas, e também verlainianos, são desenvolvidos pelas opções formais, como ritmo, assonância e aliterações, e pelas escolhas semânticas. A forma e o conteúdo atuam a fim de criar imagens, ora de movimento, ora de indolência na mente do leitor, como podemos perceber nos versos:

\author{
Les sanglots longs \\ Des violons \\ De l'automne \\ Blessent mon coeur \\ D'une langueur \\ Monotone.
}

Assim, o poema, como aponta o título, é absolutamente musical, marcado pelas aliterações nasais abundantes, que sugerem os sons soluçantes dos violinos. Os versos curtos e seus enjambements, que os fazem escorregadios e fluidos, permitem o ritmo contínuo e mole, que, por sua vez, ajudado pela recorrência dos sons, produz ressonância ininterrupta no ouvido do leitor. Os versos ficam por um período suspensos no tempo, ecoando como longos soluços ou como se imitassem a propagação dos sons musicais do violino.

A musicalidade plangente sugere a tristeza do sujeito poético, sentimento também evocado pelas escolhas lexicais. A função da música é ajudar na expressão de sentimentos vagos e imprecisos que são difíceis de demonstrar somente pelo significado das palavras. O som do poema, que se desenvolve como canção, liga-se ao significado a fim de criar no leitor a emoção visual dada pela palavra no seu valor de imagem e a emoção musical 
proporcionada pelos sons. Veja-se, por exemplo, como os versos "Les sanglots longs /Des violons/De l'automne/Blessent mon coeurD'une langueur/Monotone", sugerem a imagem do sujeito poético melancólico e entediado, o que é acentuado pelos recursos formais, os versos curtos, as aliterações nasais e a assonância da vogal /o/, que imprimem musicalidade fluida e dolente.

A música que ecoa não é qualquer música, são "soluços" produzidos por violinos, que, por sua vez, também não são quaisquer violinos, mas "violons d' automne". A escolha lexical de "sanglots" (soluços) é singular, pois o vocábulo francês traz, no plano significante, a indolência da nasal e, no plano do significado, a evocação do choro, ou seja, da tristeza, que será apresentada na segunda estrofe.

O sujeito poético afirma que esses sons plangentes, machucam seu coração, ou seja, ferem seu íntimo. Lembremo-nos dos primeiros versos:

\footnotetext{
Les sanglots longs

Des violons

De l'automne

Blessent mon coeur

D'une langueur

Monotone.
}

Será que os sons dos violinos ferem o Eu, ou esse sujeito encontra-se tão machucado que esse canto de soluços é seu próprio canto interior, em outras palavras, essa canção é a expressão da sua dor? Baseando-se idéia mallarmeniana de que "toute l'âme est une melodie" ${ }^{34}$, é possível pensar que o sujeito poético encontra-se em recolhimento intimo e, ao mergulhar em si mesmo, consegue perceber seu interior, escutar seu canto interior. A percepção subjetivada da realidade, própria da Lírica, é acentuada pelo ensimesmamento do sujeito que recolhido em si mesmo projeta seu íntimo no mundo

\footnotetext{
${ }^{34}$ MALLARMÉ, Divagations, p. 247, citado por Guy Michaud, in La Doctrine Symboliste, p. 77: "toda alma é uma melodia".
} 
exterior. O externo e o interno fundem-se e confundem-se de tal forma que a imagem do violino pode representar, simultaneamente, interior e exterior.

Ainda nessa primeira estrofe, o sujeito poético afirma ter o coração ferido (“blessé”) pelo langor e pela monotonia. O lugar da ferida é o coração, ou seja, o que há de mais íntimo no Eu. No poema, o sujeito poético começa a ser construído pela imagem de seu coração que sugere o interior do indivíduo tomado por sentimentos que evocam seu cansaço e tédio, pois a monotonia e o langor apontam para um Eu cansado e entediado com a conjuntura externa. Por isso, ele afirma, na estrofe seguinte, sentir-se sufocado pela realidade circundante:

\author{
Tout suffocant \\ Et blême, quand \\ Sonne l'heure, \\ Je me souviens \\ Des jours anciens \\ Et je pleure;
}

O sujeito poético afirma que se sente sufocado; essa sensação, segundo Michaud, pode ser chamada de ennui e é característica do mal-estar moderno que se define como um sentimento "à la fois plus violente et plus morne, véritable névrose, asphyxie du corps et de l'âme"35. Essa constatação de que tudo está sufocante e pálido também nos obriga a pensar no movimento de sensações que, como já apontado anteriormente, é duplo, de fora para dentro, mas também do interior para o exterior. O sujeito percebe tudo pálido e sufocante, por que ele mesmo encontra-se sem vida, pálido e asfixiado, como demonstram os versos "Tout suffocant/Et blême, quand".

Ao recolher-se em si mesmo no seu passado, nas suas lembranças, o sujeito poético sofre; ele chora ("je pleure") ao rememorar e comparar suas memórias com tempo

\footnotetext{
${ }^{35}$ MICHAUD, Message poétique du Symbolisme, p.52 : "ao mesmo tempo violente e morno, verdadeira nevrose, asfixia do corpo e da alma".
} 
presente, qualificado como monótono e tedioso. O choro do sujeito poético nessa segunda estrofe liga-se aos sons soluçantes dos violinos da primeira estrofe, bem como a musicalidade dos versos, as aliterações nasais e a assonância de vogais fechadas evocam o choro do sujeito poético no plano sonoro. A musicalidade que sugere o sofrimento auxilia na composição do sujeito poético em profunda crise.

O passar do tempo é torturante, pois o sujeito poético afirma que "Sonne l'heure/Je me souviens/ Des jours anciens / Et je pleure". O indivíduo encontra-se mergulhado em seu interior, em outra conjuntura espacial e também temporal; seu tempo psicológico é incompatível e independente do tempo cronológico. O passado, “des jours anciens", tempo agradável, só pode ser recuperado pela memória; é impossível para o Eu, voltar a viver essa outra época mais feliz.

O sujeito poético de "Chanson d'Automne" depara-se com presente sufocante e sofrível, por isso, deseja que o tempo passe e o leve. A imagem da folha morta sugere esse desejo de ser arrastado pelas coisas ou, em última instância, pelo Tempo:

\footnotetext{
Et je m'en vais

Au vent mauvais

Qui m'emporte

Deçà, delà,

Pareil à la

Feuille morte.
}

A folha morta representa o ápice da falta de forças do sujeito poético. A monotonia e o tédio dos primeiros versos, em estágio último, provocam, no indivíduo, tamanha apatia que o único desejo é deixar-se levar pelo vento. A imagem do vento e a da folha morta ligam-se ao título "Chanson d'Automne", pois a estação do ano marcada pela queda das folhas e pelo vento é justamente o outono. De fato, a imagem da folha morta é eficaz tanto na representação da noção de tempo do sujeito poético que quer deixa-se levar, como 
também na sua construção, pois consolida a composição do $\mathrm{Eu}$ como indivíduo melancólico e sem forças, acentuando e prolongando o sentimento de langor dos primeiros versos.

É possível também notar o movimento do vento e o vai e vem da folha morta na distribuição visual dos versos no papel; os versos curtos e repletos de enjambements parecem escorregar, num movimento de aqui e ali, ou como afirma o próprio sujeito, “deçà, delà":

Et je m'en vais

Au vent mauvais

Qui m'emporte

Deçà, delà,

Pareil à la

Feuille morte.

O vai e vem que o leitor deve fazer com os olhos na leitura do poema ao acompanhar os versos é semelhante ao movimento da folha que está à deriva, conduzida pelo vento.

Em "Chanson d'Automne", bem como em muitos outros poemas de Verlaine, podemos notar a idéia hegeliana, segundo a qual a poesia é a junção das artes plástica e da música. Nesses versos, Verlaine une a paisagem fugidia da folha morta aos sons plangentes; assim, pintura e música juntam-se para compor o poema que, ao fim e ao cabo, parece ressoar nos nossos ouvidos ao mesmo tempo em que a paisagem, evocada pelas imagens, persegue nossa mente: espécie de quadro impressionista capaz de emitir canto. Nos poemas de Verlaine, as imagens e os sons indissociáveis atuam na composição do sujeito poético como indivíduo desencantado e entediado bem como na formação da sua noção distorcida de tempo. 
A abulia do sujeito poético e seu sofrimento são tão agudos que mesmo o vento caracterizado como negativo, "mauvais" (mal), aparece como possibilidade de evasão: estar à deriva é escapar dos conflitos e das dores. O sujeito poético anseia ser tal qual "feuille morte" (folha morta); o adjetivo "morte" (morta) que qualifica folha é forte e aponta para o desejo do eu de se desprender da realidade, ou seja, de deixar de existir ou, ao menos, de deixar de sentir as coisas. Segundo Richard, é comum nos poemas de Verlaine, o sujeito poético imobilizar-se e esperar pela sua extinção, bem como pela extinção das coisas ao seu redor, atitude característica também da poesia simbolista:

Le fané verlainien veut oublier son origine. À demi penché vers son extintion prochaine, il tâche de s'immobiliser en un présent vague, vide de toute determination précise(...) L'être s'y délecte à sentir sans savoir ce qu'il sent, sans même savoir qu'il n'y a plus rien à savoir, que le monde est en train de disparaître, e qu'il ne lui reste plus pour posseder les choses que cette trace elle-même évanescente : sa sensation. ${ }^{36}$

Não se pode deixar de mencionar que a imagem da folha morta levada para lá e para cá pelo vento também constitui, na poética simbolista, forma de representar o modo pelo qual o homem e seu destino são vistos: o primeiro é "joguete" nas mãos do segundo que faz daquele o que bem quer. Outra imagem recorrente empregada para expressar essa idéia é a da embarcação à deriva.

Muitos poemas de Verlaine apresentam o sentimento que Richard chama de fané; esse adjetivo francês serve para qualificar tudo aquilo que está murcho, apagado, enfim, sem forças e, por isso, perto da completa extinção. A definição pode ser aplicada ao sujeito poético de "Chanson d'Automne", pois, nesse poema, estamos diante de um indivíduo que

\footnotetext{
${ }^{36}$ RICHARD, Jean Pierre, Poésie et Profondeur, Paris, Éditions du Seuil, 1955, p. 167 : “O apagado de Verlaine deseja esquecer sua origem. Metade inclinado para a extinção próxima, ele se encarrega de imobilizar-se em um presente vago, vazio de toda precisa determinação. O ser se delega a sentir sem saber o que sente, sem mesmo saber que não há nada para saber, que o mundo está desaparecendo e que a ele não resta mais nada a possuir a não ser o traço evanescente das coisas: sua sensação".
} 
imóvel, sem forças próprias, deseja ser levado para longe, distanciando-se da sua realidade concreta, buscando outra existência, mais frágil e próxima da total aniquilação.

O paroxismo da existência em Verlaine assume particularidades: o desejo de deixar de viver do sujeito poético, muitas vezes, não é extinguir-se completamente, mas é abandonar suas características individuais, sua origem, sua história para diluir-se no objeto que contempla. Esse processo permite libertar-se completamente da sua experiência particular adentrando no que Richard chama de "impersonnalité d' un pur sentir",37. A busca obsessiva da sensação e a recusa da pessoalidade têm como objetivo estabelecer a comunicação entre o leitor e o poema, pois a sensibilidade impessoal permite que cada um coloque nos versos sua sensação particular.

Em “Chanson d'Automne”, o vento, símbolo da agitação e da turbulência, é a única imagem de força e, por isso, se opõe a apatia do sujeito. Essa tensão imagética também se faz sentir nas sonoridades; enquanto nos dois primeiros quartetos predominam a aliteração das nasais, sugerindo monotonia e languidez, e a assonância da vogal fechada /o/, evocando o recolhimento, na última estrofe, a assonância de vogais abertas /é/ e /a/ parece quebrar a languidez, para sugerir a força do vento, elemento natural e exterior ao eu, como podemos perceber nas estâncias:

Et je m'en vais

Au vent mauvais

Qui m'emporte

Deçà, delà,

Pareil à la

Feuille morte

Portanto, com os recursos formais de sonoridade mencionados, enfatiza-se a oposição, o contraste, entre interior do sujeito poético e a realidade exterior em que ele está inserido.

\footnotetext{
${ }^{37}$ Ibidem, p. 175: "impessoalidade de um puro sentir".
} 
A falta de forças do sujeito liga-se à questão da melancolia que, como já comentado, é recorrente em Poèmes Sarturniens. Freud, em seu ensaio "Luto e Melancolia" ${ }^{38}$, aponta o caráter patológico da melancolia, estado que, segundo ele, gera desligamento da vida prática, inabilidade no agir, angústia com a passagem do tempo e obsessão pela morte; sintomas que são evidentes no poema "Chanson d'Automne". Baseados também no estudo do psicanalista, podemos dizer que estamos diante do sujeito dominado pela melancolia, desejoso de desligar-se da realidade circundante, que é sofrível, e ansioso por ser transportado para outra existência.

Ao tratar a melancolia como patologia, tanto Hypocrates, anteriormente comentado, como Freud consideram a causa desse sentimento o interior do sujeito, ou seja, a melancolia pode ser causada por razões físicas, no caso pela produção da bílis negra, ou por psicológicas, segundo Freud, a perda de algo abstrato. No entanto, é possível pensar que o sofrimento do sujeito poético vem de uma via que é dupla e que se confunde: o interno, o íntimo do eu, e o externo, a conjuntura da sociedade moderna e seus novos valores.

Ora, não podemos afirmar que a falta de vontade do indivíduo, sua melancolia, deve-se somente à realidade burguesa, à crença no progresso, enfim à sua incapacidade de adaptar-se à nova sociedade, nem tampouco, apontar como causas somente fatores psicológicos e individuais. $\mathrm{Na}$ verdade, esses elementos não são excludentes, mas complementares, na medida em que apontam para o embate entre o eu e o mundo que é representado pelos valores burgueses, porém não se pode esquecer que também antecipam o conflito moderno do eu consigo mesmo, tratando, por assim dizer, das profundezas do

\footnotetext{
${ }^{38}$ FREUD, Sigmund, "Luto e Melancolia", in Obras Psicológicas completas de Sigmund Freud, Rio deJaneiro, Ed. Imago, 1974, vol XIV, pp.275-91.
} 
inconsciente do ser humano. O crítico Fernando Pinto do Amaral considera que esse sentimento vago de mal de vivre, no qual mundo e eu estão em conflito, é a razão pela qual o sujeito poético distancia-se e isola-se:

Uma das facetas mais marcantes de tal estado de espírito gera-se a partir da profunda clivagem que o eu sente em relação ao universo exterior, diante do qual vai erguendo uma densa muralha dessa irreversível desilusão que o leva a afastar-se, quase com nojo, de tudo que povoa o monótono teatro das paixões humanas. ${ }^{39}$

Assim, a poesia do ensimesmamento desenvolve-se não só pela desilusão do homem com a modernidade, mas também pela desilusão do homem com o próprio homem. Desse modo, podemos pensar que o sujeito poético de "Chanson d'Automne", deseja evadir-se, por estar desiludido com as novidades da sociedade moderna e também com o próprio homem moderno, por isso, recolhe-se em si mesmo, e distancia-se do mundo externo, na tentativa de experimentar outro espaço e outro tempo.

Devido ao profundo ensimesmamento, o sujeito poético apresenta o que muitos críticos vão chamar de complexo de Narciso. A imagem do indivíduo que contempla o rosto nas águas aponta para a busca do Eu "profundo" que a água, símbolo do inconsciente, pode revelar. Além disso, por ser "narcisista", o Eu enxerga em tudo ao seu redor o reflexo do seu íntimo abatido e desiludido, projetando seu interior no mundo exterior.

Pensando nessa noção de correspondência baudelairiana entre interno e externo, consciente e inconsciente, outro poema de Verlaine, "Allegorie", de Jadis et Naguère é singular, pois, além do título já ser sugestivo, parece haver nele a descrição de impressões do sujeito poético, que dá a conhecer seu état d' âme a partir de paisagens:

\footnotetext{
39 AMARAL, Fernando Pinto do Amaral, "A poesia como doença da Alma", Colóquio/Letras, Lisboa,Imprensa Nacional - Casa da Moeda, n. 127/128,1993, p. 79.
} 


\begin{abstract}
Allégorie
Despotique, pesant, incolore, l'Été,

Comme um roi fainéant président un súplice,

S'étire par l'ardeur blanche du ciel complice

Et bâille. L'homme dort loin du travail quitté.

L'alouette au matin, lasse, n'a pas chanté.

Pas un nuage, pas un soufle, rien qui plisse

Ou ride cet azur implacablement lisse

Où le silence bout dans l'immobilité.

L'âpre engourdissement a gagné les cigales

Et sur leur lit étroit de pierres inégales

Les ruisseaux à moité taris ne sautent plus.

Une rotation incessant de moires

Lumineuses étends ses flux et ses reflux...

Des guêpes, çà et là, volent, jaunes et noires. ${ }^{40}$
\end{abstract}

O poema é reunião de imagens fragmentárias que o sujeito apreende da realidade; nele, não há nenhuma alusão direta aos sentimentos do Eu. O poeta exclui os aspectos humanos, o homem só aparece de maneira discreta e rápida no meio do quarto verso. As imagens comunicam sensações, de modo que o poema emerge como enigma a ser decifrado por cada leitor.

As imagens, palavras articuladas, signos dotados de significado e significante, vão somando-se, "contaminando-se" umas às outras. Desse modo, cada vocábulo, feito imagem, interfere no significado do outro a fim de formar a imagem final do poema. Já no título do poema, "Allégorie", é evidenciada a idéia de se comunicar pela forma indireta, ou ainda essa vontade de não transmitir o estado subjetivo diretamente ao leitor. O poeta adverte que vai servir-se de linguagem especial, alegórica, para dar a conhecer percepções e sensações especiais, que são incomunicáveis por meio da linguagem tradicional. No entanto, primeiramente, é preciso nos desfazer do significado corrente da palavra

\footnotetext{
${ }^{40}$ VERLAINE, “Allégorie”, Jadis et Naguère, p. 22.
} 
"alegoria" entendida como descrição metafórica que apresenta com precisão uma idéia geral, visto que, no poema, nenhuma imagem é precisa, o poeta serve-se de elementos vagos e fugidios como "l'ardeur blanche du ciel complice" (ardor branco do céu cúmplice) para transmitir seus sentimentos. Mas, então, o que o poeta quer comunicar?

Em uma primeira leitura, mesmo encontrando dificuldade para decifrar o enigma, já sentimos a atmosfera de angústia, o tédio e o desencanto diante da realidade. Esses sentimentos são construídos pelo externo, pelas imagens de enfraquecimento e de falta de forças; mais que a descrição da realidade de um indivíduo, estamos diante de sentimentos do eu transpostos para a realidade descrita, do mesmo modo que em "Chanson d'Automne" há correspondência entre interno e externo, entre íntimo do eu e contexto externo, já que o sujeito poético percebe as coisas, os objetos da natureza, com esse teor de desencanto, pois ele mesmo está desencantado e entediado com o mundo ao seu redor.

As representações exteriores em “Allégorie” que somam-se verso a verso auxiliam na construção do sujeito poético De fato, como afirma o crítico Marcel Raymond, em "Allégorie", bem como em toda poesia de Verlaine, "le sujet et l'objet font plus que se correspondre. Ils se fondre ensemble, et l'amalgame s'accomplie au-dessus du niveau de conscience. L'interne e l'externe ne font qu'un" ${ }^{\prime 4}$..

O poema, como toda poesia lírica, cuja fonte é a interioridade subjetiva, quer comunicar, por meio desse discurso imagístico, o interior do sujeito poético que não pode ser exteriorizado de maneira tradicional, mas deve emergir como "expressão poética". De acordo com a idéia hegeliana:

Il ne s'agit pas d'une simple exteriorisation de l' intériorité individuelle, d'une simple désignation de l'objet par le premier mot

\footnotetext{
${ }^{41}$ RAYMOND, Marcel,"Verlaine, les figures de sa poésie”, in Vérité et poésie, Paris, Editions de la Baconnière, [s/d],p. 180 : "O sujeito e objeto fazem mais do que se corresponderem. Eles se fundem, e a amálgama acontece debaixo do nível de consciência. O interno e o externo fazem-se um".
} 
direct, mais de l'expression ressortissant à l'art, donc différent de l'expression ordinaire, accidentalle : l'expression d'une âme poétique. ${ }^{42}$

Em "Allégorie", da mesma maneira que em "Chanson d'Automne", estamos diante de um sujeito poético que está recolhido em si mesmo: afastado do curso da vida, ele mantém-se à distância das coisas, apenas captando as imagens, mergulha numa apatia contemplativa e deseja assim permanecer. Nada ao seu redor consegue tirá-lo dessa situação de desânimo, pelo contrário, as imagens parecem acentuar tal estado.

$\mathrm{Na}$ primeira estrofe, temos a descrição de "l'été" (verão) feita a partir de sentimentos e qualidades humanas:

Despotique, pesant, incolore, l'Été,

Comme um roi fainéant président un súplice,

S'étire par l'ardeur blanche du ciel complice

Et bâille. L'homme dort loin du travail quitté

O verão é a estação do ano cheia de luz, símbolo da vida; no entanto, o sujeito poético encontra-se tão desencantado e abúlico que nem mesmo essa estação consegue mudar seu estado. Assim como o sujeito, o verão também se encontra indolente e suplicante; a estação é tomada por certo adormecimento já que, como descreve o sujeito, encontra-se bocejante ("et bâille"). Em "Chanson d'Automne” para caracterizar o sujeito como melancólico o poeta utilizava outra estação do ano, o outono, que sugeria apatia e, por ser a estação da queda das folhas, evocava a falta de forças do Eu. Aqui, nesse poema, Verlaine subverte o significado corrente do verão como estação da vida e cria outra imagem: o verão, estação do vigor, está indolente. O sujeito poético, narcisista, como

\footnotetext{
${ }^{42}$ HEGEL, G.W.F, Éthétique, Paris, Aubier, Éditions Montaigne, 1944, p. 178 : "Não se trata de uma simples exteriorização de uma interioridade individual, de uma simples designação do objeto pela primeira palavra direta, mas da expressão que torna-se arte, logo diferente da expressão comum, acidental: a expressão de uma alma poética".
} 
anteriormente já comentado, enxerga em tudo, até mesmo na imagem do verão, o reflexo do seu interior abatido e sem vida.

Com o advento da Lírica moderna, a paisagem é transfigurada ou reinventada de acordo com a sensibilidade do indivíduo, por isso, a imagem do verão, embora, prioritariamente, possa representar calor e vida, é descaracterizada de sua significação primitiva e reinventada. A recriação da realidade física no poema constrói-se para se tornar, especialmente, correspondência com a vida interior, ou seja, paisagem interior e exterior em ressonância contínua. Segundo Michaud:

Le paysage alors n'est plus un refuge, comme chez les romantiques, une nature que sympatise plus au moins avec la joie ou la douleur du poète. Avant que ne l'ait dit le philosophe, avec Verlaine, le paysage devient vraiment état d'âme. L' un et l'autre se fondent ensemble, en une intuition quase-mystique et par conséquent ineffable. La nature est donc mieux qu' un miroir ${ }^{43}$.

De fato, embora nos poemas de Verlaine, estejam presentes as idéias do movimento impressionista, muitas vezes, as paisagens verlainianas, se considerarmos a fusão do interior do sujeito poético com o exterior, configuram-se além da noção do Impressionismo observado na pintura e situam-se na fronteira entre Impressionismo e Expressionismo.

A indolência do significado dos vocábulos de "Allégorie" é enfatizada pelos significantes: a repetição das nasais $/ \mathrm{n} / \mathrm{e} / \mathrm{m} /$ sugerem, no plano fônico, a letargia presente no campo semântico. Além disso, os enjambements, abundantes no poema, contribuem para o ritmo contínuo, que provoca a sensação de entorpecimento no leitor; a frase poética parece escorregar lentamente de verso em verso, fluida, assim como as imagens. O poema,

\footnotetext{
${ }^{43}$ MICHAUD, Message Poétique du Symbolisme, p. 115 : "A paisagem não é mais um refúgio, como era para os românticos, uma natureza que simpatizava mais ou menos com a alegria ou a dor do poeta. Antes de dizer o filósofo, em Verlaine, a paisagem torna-se verdadeiramente um estado de alma. Uma e outro se fundem em uma intuição quase mística e por conseqüência inefável. A natureza é, portanto, melhor que um espelho".
} 
embora seja um soneto, forma clássica, é construído por enjambements que permitem a acentuação simbolista: desloca-se a cesura dos alexandrinos, acentuando-os na $4^{\mathrm{a}}, 8^{\mathrm{a}}$ e $12^{\mathrm{a}}$ sílabas poéticas. Esses alexandrinos trímetros, criação simbolista, conferem mais musicalidade à composição.

A imagem do homem que dorme depois de ter deixado o trabalho, "L'homme dort loin du travail quitté" bem como o torpor que "contamina" o dia podem sugerir que o momento descrito pelo sujeito poético é o poente. Essa ocasião, assim como o outono, é preferida pelos simbolista-decadentistas, pois aponta para o enfraquecimento, para o fim do dia e, por isso, reflete o estado de espírito lasso e melancólico, como podemos observar também nestes versos de Poèmes Saturniens:

Une auble affaiblie
Verse par les champs
La mélancolie
Des soleils couchants. ${ }^{44}$

Nessa estância, o sujeito poético busca, no ambiente, imagens que possam traduzir seu estado de espírito melancólico; o poente sugere a vontade do indivíduo de desfazer-se e de deixar de existir. Os versos afirmam que a melancolia vem do pôr-do-sol, do "soleils couchants", no entanto, não é o sol que se encontra melancólico, mas o sujeito poético que, mergulhado na melancolia, tem a percepção das coisas modificada e enxerga tudo tomado por esse pesar.

Devido ao desencanto com a realidade, o sujeito de "Allegorie" recolhe-se em si mesmo e acha-se em estado de cisma: processo lento e crescente de afastamento da realidade, ou seja, rejeita toda a relação com algo exterior a ele, para mergulhar em si mesmo. Assim, permanece à distância, apenas contemplando o findar do dia.

\footnotetext{
${ }^{44}$ VELAINE, “Soleils Couchants”, Poèmes Saturniens, p. 29.
} 
No último verso da primeira estrofe de "Allégorie", "Et bâille. L’homme dort loin du travail quitté", a imagem prosaica de um homem que dorme, estabelecida pelo corte proporcionado pela estrutura gramatical do verso - há um ponto final e uma frase que começa no meio dele, destoa do poema, pelo fato de que esse homem não é o sujeito poético, mas representa a sociedade que está alheia ao desencanto do Eu e à sua situação de decadência. Portanto, o único elemento dotado de humanidade parece estar mais alheio à dor do sujeito do que a própria natureza.

No segundo quarteto, temos a imagem de um pássaro, a cotovia, que está lassa e que não canta:

L'alouette au matin, lasse, n'a pas chanté.

Pas un nuage, pas un soufle, rien qui plisse

Ou ride cet azur implacablement lisse

Où le silence bout dans l'immobilité.

A cotovia era tida, pelos gauleses, como pássaro sagrado, por isso, permanece por toda a história do folclore francês e das crenças populares francesas como ave do bom augúrio; o canto da cotovia representa a alegria em oposição ao do rouxinol que é triste. $\mathrm{O}$ simbolismo evocado pelos pássaros é comum em Verlaine e aparece em outros poemas; essa predileção talvez seja proveniente da ascendência gaulesa dos franceses. No poema, a imagem da cotovia pode relacionar-se com o contexto finissecular, ou seja, com a reificação, a "coisificação" do homem e da sua arte, que passou a ser vista como mercadoria. O pássaro pode representar o poeta que não tem mais lugar na sociedade, visto que a arte tornou-se mercadoria e a sua poesia não tem mais força para mudar a realidade e, por isso, ele encontra-se em silêncio e imóvel. O poeta, que na Grécia antiga era visto como doador de sentidos e no Romantismo como guia, a partir de Baudelaire, como 
apontado no primeiro capítulo, perde sua aura e torna-se um sujeito desajustado e maldito, dominado pela noção de estar à margem do tempo e do espaço em que vive.

O silêncio, evocado pela imagem da cotovia muda e lassa, é prolongado no decorrer do quarteto, como mostram os versos

Ou ride cet azur implacablement lisse

Où le silence bout dans l'immobilité.

A figura do pássaro ajuda na construção da imagem do sujeito poético como indivíduo desencantado que não tem mais nada a dizer.. Essa apatia deixa transparecer um indivíduo que está desencantado e entediado com o mundo ao seu redor. A sensação de tédio é reforçada na camada sonora pelos enjambements, ou seja, pelo encadeamento dos versos que deixam a frase gramatical longa e "pesada".

Assim, o ennui, o cansaço do homem moderno, é causado pelos avanços científicos que em certa medida não melhoraram a condição de vida humana, já que foram apenas ilusões passageiras. Na verdade, o sujeito poético, assim como será apontado nos poemas de Pessanha, sente-se "des-encantado", pois foi tirado do encanto de que o progresso traria grandes benefícios para a essência humana.

Em "Allégorie", o sentimento de atonia e silêncio é corroborado pelas cigarras que aparecem no primeiro terceto:

L'âpre engourdissement a gagné les cigales

Et sur leur lit étroit de pierres inégales

Les ruisseaux à moité taris ne sautent plus.

Esses insetos, caracterizados pelo canto incessante que estridula ao calor do sol, no poema, estão tomados pelo "l'âpre engourdissement" (amargo entorpecimento), ou seja, encontram-se em estado de indolência e torpor. Portanto, as cigarras agregam-se à imagem 
da cotovia para representar a situação do poeta, já que os dois elementos, que se singularizam pela produção do canto, estão tomados por desânimo e pelo silêncio.

As imagens do poema, o verão indolente, a cotovia muda e as cigarras entorpecidas bem como os sons nasais, colaboram, verso a verso, na construção da imagem do sujeito poético como letárgico e apático, pois esses elementos imagéticos ou formais sugerem a sua quietação e ausência de desejos. Essa idéia de contemplação imóvel é patente também nesta estância de outro poema de Jadis et Naguère:

Immobiles, baissons nos yeux vers nos genoux.

Ne pensons pas, rêvons. Laissons faire à leur guise

Le bonheur que s'enfuit et l'amour qui s'épuise,

Et nos cheveux frôlés par l'aile des hiboux. ${ }^{45}$

Nesses versos de “Circonspection”, título que já aponta para o recolhimento íntimo, o sujeito poético deseja ficar imóvel, mergulhar em si mesmo, enquanto as coisas acontecem ao seu redor, pois a realidade é decepcionante, como ele mesmo afirma: a felicidade "foge" e o amor se esvai. A voz lírica, nas obras de Verlaine, busca muitas vezes, esse aquietar-se da realidade fugidia das coisas no seu mundo interior. De acordo com Jean Pierre Richard, é possível sentir, na poética verlainiana, o que o crítico denomina "quietisme du sentir" que se configura como:

Repôs, silence, détente, ouverture. Volonté de ne pas provoquer l'exterieur - croyance en une activité émanatoire des choses - brises souffles, vents, venus d'aillheurs, - sur la laquelle l' homme reconnâit sans pouvoir, attente de cette grâce imprevisible, la sensation, messagère d' un univers lontain. ${ }^{46}$

\footnotetext{
${ }^{45}$ Idem, "Circonspection", Jadis et Naguère, , p. 24.

${ }^{46}$ RICHARD, Op. Cit, p. 166: "Repouso, silêncio, descanso, abertura. Vontade de não provocar o exterior crença numa atividade emanante das coisas - brisas, sopros, ventos, vindos de alhures - sobre aquelas o homem se reconhece sem poder, a espera dessa graça imprevisível, a sensação, mensageira de um universo distante".
} 
No entanto, no último terceto de "Allégorie", dois elementos, "moires" (miragens) e "guêpes" (vespas), introduzem movimento ao poema:

Une rotation incessant de moires

Lumineuses étends ses flux et ses reflux...

Des guêpes, çà et là, volent, jaunes et noires.

As miragens luminosas que vão e vêm, como fluxo de imagens que passam pelos olhos do indivíduo, parecem torturar o sujeito poético, visto que ele não consegue apreendê-las, pois estão em movimento e são instáveis. Essa incapacidade do Eu frente ao fluir das imagens, ou seja, a impossibilidade de captar o que quer que seja é topos da poesia simbolista e moderna e constitui mais uma maneira de ilustrar o desajuste entre eu e mundo, entre eu e realidade circundante - e trata-se de um desajuste absolutamente doloroso, pois, se o indivíduo não consegue captar o real, a possibilidade de estabelecer correspondências também diminui. Esse tema aparece também no poema "Imagens que passais pela retina", de Camilo Pessanha.

O movimento das imagens e das vespas que parecem afligir o sujeito é acentuado, no plano sonoro, pela aliteração das sibilantes /s/ e /z/, que sugerem o barulho dos insetos. De fato, assim como as vespas que estão por toda parte, “çà et là", as aliterações das sibilantes perpassam todo o poema. Portanto, o trabalho de artífice do poeta, na construção das camadas formais, contribui para a cristalização da imagem, já que ao mesmo tempo em que "vemos" a palavra, conseguimos ouvir os sons, no caso, os zumbidos das vespas.

De novo, da mesma maneira que em "Chanson d'Automne", cria-se no final do poema tensão característica da poesia finissecular. Nesses dois poemas de Verlaine, as últimas estrofes introduzem movimento às composições e destoam do restante que é marcado pela impassibilidade e falta de forças. A tensão acentua a idéia de que o mundo 
do sujeito e o mundo das coisas não coincidem ou ainda o tempo interior do sujeito e o tempo exterior não são equivalentes.

A transitoriedade das miragens que aparecem no último terceto de "Allégorie" incomoda o sujeito poético, pois, de modo oposto, o tempo psicológico do indivíduo é lento. Há descompasso entre o tempo do eu e do tempo do mundo, que sente o tempo excessivamente breve para as coisas e, demasiadamente, longo para si mesmo; esse desajuste deve-se à consciência em crise do sujeito poético que percebe e capta as coisas e as imagens conforme seu íntimo desencantado.

Por fim, podemos notar que os dois poemas analisados de Verlaine, "Chanson d'Automne" e "Allégorie", embora muito diferentes na estrutura formal como também nas imagens criadas pelo poeta, constroem o mesmo estado do sujeito poético: desencantado e desajustado, como já aparecia na lírica de Baudelaire e Cesário, não consegue participar da realidade, por isso, recolhe-se em si mesmo, vivendo num outro espaço e também num outro tempo, que não são outros se não seu interior. 


\section{CAPÍTULO III - CAMILO PESSANHA}

Nos poemas de Clepsidra, a relação do sujeito poético com o tempo é fundamental e aparece em todos eles, ora explicitamente, ora apenas sugerida por imagens que traduzem o état d'âme do eu. Além disso, os procedimentos formais colaboram para cristalizar a composição do sujeito poético em crise, bem como o passar do Tempo, criando quer pelo apelo sonoro, quer por recursos visuais, o retrato do indivíduo em crise do final do século XIX. Assim, afirma o crítico Seabra Pereira sobre as características dessa poesia:

Uma poesia anti-confessional e anti-didáctica, anti-oratória e antidescritivista, comunica-se nos cheia de sentidos; uma poesia semeada de correlações e imagens negativistas, insinua-se-nos prenhe de uma alusiva e recôndita sabedoria; uma poesia de esteticismo implícito e incoercível, invade-nos com a serenidade da superação do niilismo pela justificação da existência no acabamento da obra e da beleza nela (..) incontornável assumpção da poiesis como fim ${ }^{47}$.

De fato, como afirma Seabra Pereira, os poemas de Pessanha, muitas vezes, nos fascinam devido a suas correlações de imagens, que são sempre negativas pois, expressam o íntimo perturbado do sujeito poético. Essa poética anti-didática e anti-descritivista de Pessanha, que se vale dos elementos externos, não para descrever, mas para comunicar outra realidade, apresenta-se de maneira salutar nos versos de "Foi um dia de inuteis agonias"

Foi um dia de inuteis agonias,

- Dia de sol inundado de sol.

Fulgiam nuas as espadas frias,

- Dia de sol inundado de sol.

\footnotetext{
${ }^{47}$ SEABRA PEREIRA, Op. Cit., p. 153.
} 
Foi um dia de falsas alegrias.

- Dahlia a esfolhar-se o seu molle sorriso.

Voltavam os ranchos das romarias,

- Dahlia esfolhar-se o seu molle sorriso.

Dia impressível, mais que os outros dias,

Tão lucido, tão pallido, tão lucido!

Diffuso de theoremas e theorias...

O dia fútil, mais que os outros dias

Minuete de discretas ironias...

Tão lucido, tão pallido, tão lucido ${ }^{48}$ !

Ao terminarmos a leitura do poema, somos tomados por duas sensações: fascínio e desconcerto, ambas derivam do trabalho poético empreendido por Pessanha na construção dos significados, o qual passa pela desconstrução lógica dos elementos sensíveis e da realidade circundante e pelo estilhaçamento da sintaxe. Conseguimos, já na primeira leitura, perceber a sensação de monotonia que perpassa todo o poema, sem dúvida, devido às repetições lexicais e sonoras que parecem entorpecer o leitor; no entanto, a sua significação completa parece estar velada, como se, simultaneamente, o poema conseguisse cumprir duas funções paradoxais - exprimir e esconder. É exatamente esse paradoxo que nos seduz em muitos poemas de Pessanha, como corrobora Eugênio de Andrade:

sedução maior pelos poemas de Pessanha está na capacidade de sugerir, de insinuar, de não concluir o que fora começado a dizer, como se dizer não fora para Pessanha o que mais importava. Era a indecisão tornando matéria de poesia, criando-se com essa reticência um enleio, uma sutil cumplicidade com o silêncio entre pensar e sentir. ${ }^{49}$

De fato, como aponta Fernando Guimarães em Simbolismo, Modernismo e

Vanguardas, com o advento da Lírica Moderna, cria-se nova poética que se concentra na

\footnotetext{
${ }^{48}$ PESSANHA,"Foi um dia de inúteis agonias", in Op. cit, p.100.

${ }^{49}$ ANDRADE, Eugênio de, "Camilo Pessanha, o mestre", Persona, Porto, Centro de estudos pessoanos, número 10, junho de 1984, p. 10.
} 
busca interior do Eu que conduz a total substituição da estética da mimese pela figuração, substituição que, como evidenciado no primeiro capítulo, já se faz sentir em Baudelaire e Cesário Verde.

No entanto do que trata o poema? De onde vem exatamente seu hermetismo e fascínio? Estamos diante de percepções fragmentadas de um sujeito que estático enxerga o tempo passar. A dificuldade de compreensão reside não no léxico do poema, como é comum em muitas obras simbolistas, nas quais se encontram muitos vocábulos raros; o hermetismo, nesse caso, deve-se aos traços mínimos e fragmentários da realidade. O poema de Pessanha constrói-se por meio de imagens que comunicam o íntimo do sujeito, que sugerem o que é incomunicável pela linguagem tradicional. A lúcida consciência estética dos simbolistas descobre na sugestão a nova linguagem, cabendo ao poeta, por meio dela, evocar uma emoção através de um objeto, ou evocar um état d'ame:

La suggestion peut se que ne pourrait pas l'expression. La suggestion est le langage des correspondences et des affinités de l'âme et de la nature. Au lieu d'exprimer des choses leur reflet, elle pénètre en elles et devient leur propre voix. La suggestion n'est jamais indifférent et, d' essence, est toujours nouvelle car c'est le caché, l'inexpliqué et l'inexprimable des choses qu' elle dit. ${ }^{50}$

Assim, embora o sujeito poético não apareça explicitamente no poema "Foi um dia de inuteis agonias", a subjetividade lírica, a maneira de o Eu sentir e conceber o mundo, faz-se fortemente manifesta por meio de imagens; nesse poema plástico, a realidade é moldada e transformada de acordo com as percepções do indivíduo. A construção do

\footnotetext{
${ }^{50}$ MORICE, Charles, "Littérature de tout à l' heure" (1889), p. 378, citado por MICHAUD, La Doctrine Symboliste, p. 76: "A sugestão pode o que não poderia a expressão. A sugestão é a linguagem das correspondências e das afinidades da alma e da natureza. No lugar de exprimir o reflexo das coisas, ela penetra-as e torna-se sua própria voz. A sugestão não é nunca indiferente, essencialmente, é sempre nova porque ela diz o escondido, o inexplicável e o inexprimível das coisas".
} 
sujeito poético no poema é dada pelas escolhas lexicais, sobretudo pela abundância de adjetivos, que traduzem o estado do indivíduo em crise como: "inúteis", "falsas", "molle", "pallido". Estabelece-se no poema a correspondência entre o interno e o externo, visto que o sujeito enxerga tudo com tal grau de apatia, porque se encontra, prioritariamente, apático, assim, as imagens externas são elementos de construção do sujeito poético que por meio delas é caracterizado como abúlico e desencantado.

A poesia sublima a linguagem e, mais do que isso, transcende seu próprio valor, na medida em que deixa de ser utensílio, isto é, não se comporta mais como conjunto de signos móveis e significantes para ser apenas, ou, sobretudo, poema. Por isso, segundo Octavio Paz, "a linguagem tocada pela poesia cessa imediatamente de ser linguagem" 51. Assim, Pessanha, por meio de combinações inusitadas como "molle sorriso" ou "inuteis agonias" parece libertar as palavras da sua significação latente particular, para atingir outra, totalmente nova e só possível no poema.

O poema é a descrição de um dia observado por um sujeito que parece estar à margem da sociedade, não participar da realidade exterior, ou seja, os versos resumem-se na problemática da apreensão da realidade por um sujeito que contempla as coisas acontecerem ao seu redor. Nos dois primeiros quartetos, têm-se certos traços de acontecimentos típicos provincianos: pequeno movimento de pessoas que viviam em aldeias que podem estar voltando de uma jornada de trabalho ou, ainda, de reuniões típicas para rezas. Já nos tercetos, temos somente a caracterização deste dia. A composição iniciase com o verbo ser no passado, o que indica que, provavelmente, este dia já acabou e está presente apenas na memória do sujeito que o descreve e o analisa:

\footnotetext{
${ }^{51}$ PAZ, Octavio, Signos em Rotação, (Trad. Sebastião Uchoa Leite), São Paulo, Editora Perpectiva, 1996, p.57.
} 
Foi um dia de inuteis agonias,

- Dia de sol inundado de sol.

Fulgiam nuas as espadas frias,

- Dia de sol inundado de sol

Embora se trate da descrição de determinado dia observado pelo sujeito poético, a realidade exterior é apresentada a partir de indícios mínimos e vagos. O que mais transparece no poema é o interior do Eu que viveu esse dia. Nesses primeiros versos, o leitor é comunicado apenas de que era um dia com muito sol, "inundado de sol", e que havia espadas nuas e frias que brilhavam, provavelmente, devido aos raios solares que incidiam sobre elas, já que se encontravam nuas, ou seja, desembainhadas. A expectativa do leitor é quebrada, pois, após a afirmação inicial, esperava-se a explicação da razão das “inuteis agonias", mas nada é dito claramente, o leitor deve interpretar e descobrir por meio dos indícios vagos dados pelas apreensões do sujeito poético.

A sinestesia aparente na imagem das espadas "nuas e frias", visão e tato, implica nas espadas estarem visíveis, desembainhadas, e a frieza das lâminas, na possibilidade do sujeito as ter sentido. Ora, a espada é objeto que fere duplamente, corta e perfura; podemos dizer que essa simbologia de dor acentua a noção de sofrimento dos versos, prolongando o tema das "inuteis agonias". Além disso, a frieza das espadas e a sensação de dor são sugeridas pelo elemento sonoro, a assonância da vogal /i/, que além de proporcionar musicalidade aos versos, evoca no plano sensível, na forma, o que é dito pelo tema, por exemplo, "inuteis", "dia", "agonia" e "frias".

O segundo quarteto, também inicia com o verbo "ser" no passado, com estrutura semelhante a do primeiro:

Foi um dia de falsas alegrias,

- Dahlia a esfolhar-se o seu molle sorriso.

Voltavam os ranchos das romarias,

- Dahlia a esfolhar-se o seu molle sorriso. 
A diferença entre o primeiro verso desse quarteto se comparado com o primeiro verso do primeiro quarteto é a substituição de "inuteis agonias" por "falsas alegrias"; ambas as designações que auxiliam na composição do íntimo do sujeito poético. Essas expressões que se referem ao dia evidenciam a relação dolorosa do Eu diante da realidade circundante, pois apresentam o sujeito poético como alguém pessimista e desencantado diante da vida, pois ela se resume a inutilidades e ilusões; todas as alegrias, são falsas, constituem apenas ilusões que são destruídas rapidamente.

O topos das ilusões desfeitas é prolongado e acentuado pelos versos pares do segundo quarteto, como vemos abaixo:

— Dahlia a esfolhar-se o seu molle sorriso.

O desfolhar evidencia o passar do tempo e a fugacidade das coisas, pois a dália é flor de características delicadas e sensíveis que perde as pétalas, ou seja, que morre, rapidamente. Essa efemeridade, bem como o passar do tempo, também é sugerida no plano sensível, pela aliteração das fricativas e sibilantes que perpassa todo o quarteto.

Outra perspectiva interessante que nos proporciona a imagem da dália é que seu desfolhar aponta também para o processo de "des-encanto", pelo qual passou o sujeito poético, visto que as dálias são conhecidas justamente como flores das ilusões devido a sua beleza e baixa durabilidade. As ilusões, as "falsas alegrias", enganam, são fugazes, duram pouco e desfazem-se rapidamente, tal qual o desfolhar da dália. Além disso, a escolha imagética da dália pelo poeta é extremamente genial e cuidadosa, visto que essa flor liga-se ao ambiente descrito pelo poema: as dálias são flores exóticas e delicadas que não resistem ao frio e necessitam de temperatura quente e luz intensa e difusa, ou seja, a atmosfera descrita pelo sujeito poético, "dia inundado de sol" e "difuso de teoremas e teorias". 
A imagem da dália destoa do acromatismo do poema. Sem dúvida, hoje em dia, existem dálias de várias cores, devido aos avanços da botânica; no entanto, se pensarmos que sua cor antigamente era, sobretudo, vermelho intenso, a escolha dessa flor torna-se interessante no contexto de Clepsidra. Lembremo-nos das duas últimas estrofes do poema "Branco e Vermelho":

A dor, deserto imenso, Branco deserto imenso, Resplandecente e imenso, Foi um deslumbramento. Todo meu ser suspenso, Não sinto já, não penso. Pairo na luz suspenso Num doce esvaímento.

Ó morte, vem depressa, Acorda, vem depressa, Acode-me depressa, Vem-me enxugar o suor, Que o estertor começa. É cumprir a promessa. Já o sonho começa... Tudo vermelho em flor... 52

Nessas estâncias, o acromatismo perpassa toda a composição até o último verso, no qual a coloração vermelha de uma flor aparece. Além disso, a relação dor e luz também é a mesma de "Foi um dia de inúteis agonias" visto que o excesso de luz, símbolo do exagero de conhecimento, pode ofuscar e causar dor, como apontam os tercetos do soneto. Assim, podemos dizer que a imagem da dália, flor vermelha, tal qual acontece no último verso de "Branco e Vermelho", destoa do sentimento de luz e dor, desenvolvidos em todo o soneto "Foi um dia de inúteis agonias" e evoca outra realidade, mais agradável, que passa pelo interior do eu. Num nível de significação ainda mais alegórico, se pode pensar que a dália, vermelha, evoca pela intensidade desta cor, a vida, o sangue, que é seiva da vida. Se essa

\footnotetext{
${ }^{52}$ PESSANHA, "Branco e Vermelho", Op. cit. p. 135.
} 
leitura é possível, a dália a esfolhar-se é ainda sinal de vida que se esvai lentamente. Nessa perspectiva, a possível contradição é desfeita, pois, se a vida vai se desfazendo como a dália a esfolhar-se, o indivíduo vai perdendo a cor, a intensidade do sangue, e assumindo a transparência, a brancura excessiva, que evoca o "dia de sol inundado de sol".

Nos tercetos do soneto "Foi um dia de inuteis agonias", a caracterização do dia continua e torna-se ainda mais subjetivada, já que os traços da realidade exterior parecem evanescer-se ainda mais. Lembremo-nos dos versos:

Dia impressível, mais que os outros dias,

Tão lucido, tão pallido, tão lucido!

Difuso de teoremas e teorias,

O dia fútil, mais que os outros dias

Minuete de discretas ironias!

Tão lucido, tão pallido, tão lucido!

Os tercetos iniciam-se com a afirmação do sujeito poético de que este dia de que trata no poema é "impressível", mais que os outros. Ora, esse dia, comum e tedioso, destaca-se dos restantes, justamente, por ser o dia que o sujeito descreve e analisa, tendo em vista não o exterior, mas o estado interior do indivíduo. Portanto, da mesma maneira que nas composições de Verlaine, em todo o poema constrói-se o movimento de vai e vem, de dentro para fora, do íntimo torturado do eu para o mundo. Nessa oscilação entre eu e mundo, o que mais avulta é o interior do sujeito; logo, as marcas do "dia impressível" fazem-se presente, não devido aos acontecimentos externos, comuns e provincianos, mas porque o eu mergulha-se no seu íntimo em crise. Além disso, o dia de "inuteis agonias" é visto de modo a ajudar na construção do caráter estático do sujeito poético: as cenas acontecem, os eventos do dia se sucedem, como de costume, mas tudo parece dar-se em câmera lenta e num grau de insignificância - aspectos que derivam da percepção do eu, do seu estado de alma, da relação que o eu tem como o mundo. $\mathrm{O}$ "timing" com que o sujeito 
poético olha o mundo é completamente diferente do "timing" do mundo e das coisas. Tudo adquire lentidão, hieratismo.

A noção do dia claro, iniciada nos quartetos, é prolongada nos tercetos, pois apesar de não haver mais referências ao sol, o sujeito afirma que os dias são lúcidos, mas também pálidos. Podemos pensar que lúcido refere-se ao externo que está "inundado de sol", enquanto pálido, ao interno, ou seja, ao íntimo do eu que se encontra sem vida, apático, possivelmente, devido ao desencanto e frustrações evidenciadas pelas expressões "falsas alegrias" e "inuteis agonias".

A imagem do dia claro, cheio de sol, é forte, mas não tem força suficiente para mudar o que está pálido; ao contrário, a claridade chega a acentuar o sofrimento do Eu, tornando o sujeito completamente apático e desiludido. Apesar de Camilo Pessanha, neste poema, subverter a imagística decadente-simbolista - a qual se apóia em imagens de outono e poente, na meia-luz -, a claridade do poema serve justamente para acentuar a decadência do sujeito que não consegue expressar nem mínima vontade, ao contrário; a sua situação de crise é tão intensa, que contamina todo o ambiente ao seu redor.

O "dia lucido", cheio de luz, aponta também para o excesso de conhecimento do sujeito, que sofre por isso. O excesso de luz do dia, marcado pelo sol excessivo, torna tudo pálido, já que a luz excessiva ofusca a visão. Assim, a luz excessiva simboliza o excesso de conhecimento do sujeito poético que, por isso, enxerga as coisas de maneira diferente, pálida. O indivíduo fica a pensar as coisas, criando, como os versos afirmam, teoremas e teorias, ao invés de participar da realidade. Além disso, o vocábulo "difuso" empregado nos tercetos liga-se ao campo semântico de luz de todo o poema, visto que a difusão consiste no espalhamento de raio luminoso através de meio irregular, da mesma maneira que o sol do poema ilumina de modo desigual, idéia traduzida pelos traços soltos e irregulares da realidade. 
A falta de ação, característica do sujeito poético, é sugerida pela escassez de verbos do soneto; nos quartetos há apenas três verbos de ação: "fulgiam", "esfolhar-se" e "voltavam" e o verbo de ligação "ser" conjugado no passado, bem como o particípio passado "inundado" - que, entretanto, pode ser tido como verbo adjetivado. Já nos tercetos, os verbos estão totalmente ausentes, todos os versos são sintagmas nominais. A falta de verbos acentua o caráter abúlico do sujeito, bem como a monotonia e o tédio.

A repetição e o léxico limitado do soneto "Foi um dia de inúteis agonias", ou seja, a insistência nas mesmas palavras, acentuam a monotonia e evidenciam o tédio do sujeito poético que enxerga tudo sempre igual. Da mesma maneira que o sujeito está cansado porque enxerga tudo sempre igual, o leitor também experimenta um pouco desse cansaço, na medida em que, ao ler o poema, depara-se com palavras e estruturas repetidas. O dia fútil transparece um sujeito entediado que perde um pouco a noção temporal. O sujeito tem clareza mental, analítica: sabe que esse dia engana, em razão de ser o dia que ele analisa, podendo, então, se tornar especial, embora ele saiba que o dia evocado é como todos os outros dias, já que o sujeito poético tem a noção temporal deturpada pelo tédio, que torna os dias iguais, sensações sem fim.

Embora a composição seja um soneto petrarquiano com versos decassílabos, ele não segue o modelo de tese, antítese e síntese, desenvolvendo-se a partir de fragmentos de percepções sensoriais: fragmentos do sentir íntimo do sujeito, como "inúteis agonias" e "falsas alegrias"; fragmentos do ver, como "lúcido" e "fulgiam as espadas"; e, por fim, fragmentos do tato: espadas "frias", mole sorriso" que são apresentados segundo a lógica íntima de percepção do mundo e das coisas; portanto, sem encadeamento lógico e seqüencial, visto que as imagens dos quartetos podem ser postas em qualquer ordem, pois são estilhaços da realidade. Assim, o sujeito poético mostra o externo e o seu íntimo a partir de fragmentos. 
No poema, a sintaxe apresenta-se fragmentada e "picada"; cada verso é estanque, não há articuladores coordenativos, nem subordinativos. Tal qual a realidade e o íntimo do sujeito, a sintaxe fragmenta-se e o processo de subordinação dos versos tem de ser construído mentalmente pelo leitor. O processo de fragmentação da sintaxe evidencia o eu que percebe o mundo por fragmentos e estilhaços, pois, segundo Spaggiari "a realidade refrange-se como num espelho partido: assim dissociada e fragmentada, oferece os seus fragmentos cortantes para construir correlações e analogias" 53 .

As imagens fragmentadas como estilhaços do sentir íntimo do sujeito poético bem com a sintaxe "picada" permitem a construção do Eu como indivíduo fragmentado, pois a realidade e as sensações estilhaçadas apenas podem ser percepções de um sujeito que também se encontra "aos pedaços".

Essa técnica de fragmentação da sintaxe não implica em quebra da musicalidade; é justamente a desarticulação do verso que permite a elasticidade da acentuação dos decassílabos do soneto, deixando todo o poema mais fluido. Embora o fato de o soneto ser composto por versos decassílabos possa evidenciar certo classicismo, essa idéia é desfeita quando examinamos a acentuação simbolista; o poeta combina dois decassílabos clássicos, o heróico e o sáfico, com o "decassílabo modernizado", que aparece, por exemplo, nos versos pares dos quartetos, nos quais a acentuação é deslocada para a $4^{\mathrm{a}}$; $7^{\mathrm{a}}$; e $10^{\mathrm{a}}$ sílabas poéticas. Se recortarmos as palavras acentuadas do soneto, temos a noção principal do poema, como por exemplo, no primeiro quarteto: "inuteis", "agonias", "nuas", "frias", "sol", "inundado", “sol".

Essa acentuação ternária dos versos liga-se ao campo semântico do último verso do soneto: "Minuete de discretas ironias!". O minute ou minueto abarca duas significações, primeiramente é uma dança em compasso ternário de origem francesa, popular no século

\footnotetext{
53 SPAGGIARI, Bárbara, O simbolismo na obra de Camilo Pessanha, Lisboa, Ministério da Educação e das Universidades,1982, p. 48.
} 
XVIII; no entanto, posteriormente, tornou-se hábito dos grandes compositores, como Mozat, Beethoven, incluir minuetos nas suas sonatas e sinfonias, para expressar grande sentimento de angústia. A segunda designação é a que mais avulta no poema, pois o minuete pode representar a própria composição do poeta, ou seja, seu poema, com musicalidade abundante que expressa a angústia do sujeito poético.

O homem, no contexto do século XIX, na sociedade da Reificação, deixou de ser visto como elemento constituído de humanidade e passou a ser considerado como peça de uma máquina, perdendo-se assim a noção de totalidade. Na medida em que o processo capitalista foi se expandindo, as idéias de reificação e fragmentação foram ampliadas; cada indivíduo comporta-se como mônoda. As mônodas são pequenas esferas que se chocam, mas que são incapazes de se fundir. Assim, como afirma João Camilo, a respeito da poesia de Pessanha, a fragmentação dos versos implica apresentar este mundo do final do século XIX em crise:

A não expressão das relações lógicas entre as diferentes partes do discurso dá origem a uma poesia essencialmente fragmentária, em que os diversos elementos ficam a pairar numa liberdade relativa no poema como totalidade fechada sobre si mesma. As relações entre as partes do poema tornam-se em muitos casos puramente implícitas e cabe ao leitor pressenti-las, e se necessário através de varias tentativas encontrá-las(...) O poema perde desse modo em parte a capacidade de nos relevar sentidos claros, de se nos impor como a ilustração de uma visão de mundo transparente. Mas a época de Camilo Pessanha é de crise (crise de valores, pessimismo ontológico) e em vez de apresentar uma visão de mundo ou de propor para o leitor elementos para uma biografia do poeta, os simbolistas pretendem simplesmente, ou antes de mais nada, comunicar impressões, sugerir ambientes. Encarada deste ponto de vista a estética do fragmento implicada pela não expressão parcial ou total das relações lógicas no interior do poema aparece antes de mais nada como uma técnica de composição adaptada à expressão de um estado de espírito determinado pelas condições sócio-históricas ${ }^{54}$.

\footnotetext{
${ }^{54}$ CAMILO, João, “A Clepsidra de Camilo Pessanha”, in Persona , nº10, p. 21.
} 
O contexto de crise de individualização excessiva e de fragmentação do eu, típicos do final do século XIX, geram outro tema importante: a busca pela unidade perdida é patente na poética simbolista e só pode ser alcançada com a morte; por isso, a imagem da Ofélia morta sobre as águas é cara a essa poética e está presente em mais composições, como nos versos abaixo:

Ficae, cabellos d'ella fluctuando, E, debaixo das águas fugidias, Os seus olhos abertos e scismando...

Onde ides a correr, melancolias? - E, refractadas, longamente ondeando, As suas mãos translúcidas e frias... 55

A Ofélia morta nas águas representa o homem em constante conflito com a sociedade; além disso, o Simbolismo possui predileção por tal imagem porque simboliza a reintegração do homem ao cosmos. A Ofélia está boiando e forma-se ao seu redor um halo para sugerir que ela está lentamente sendo desfeita, decomposta pela água. Nesse sentido, a morte adquire concepção positiva porque é a libertação dos sofrimentos. O sujeito mostrase desencantado com a realidade e frustrado, de modo que a vida é vista sob a perspectiva pessimista de sucessão de impossibilidades ou perdas irreparáveis, ou, ainda, como o sujeito poético afirma no soneto "Foi um dia de inuteis agonias", a vida limita-se a "inuteis agonias", a "falsas alegrias" e a "dias futeis".

No soneto "Foi um dia de inuteis agonias", os recursos estilístico-formais, sobretudo a sintaxe fragmentada e a repetição, contribuem para expressar a construção do sujeito poético e sua condição de crise, já que aparece mergulhado em "inúteis alegrias" e em "dias fúteis", ou seja, numa realidade circundante que lhe é desagradável e lhe causa sofrimento. Essa frustração do Eu é decisiva na perspectiva temporal deturpada, pois faz o

\footnotetext{
${ }^{55}$ PESSANHA, “Paisagens de Inverno II”, Op. cit., p. 89.
} 
indivíduo sentir que o tempo passa lento demais para si mesmo e rápido demais para as coisas.

A perspectiva pessimista, base do Simbolismo e do Decadentismo, provoca nos sujeitos a vontade de deixar de viver. O desejo de morte é constante. Esse põe fim aos sofrimentos do indivíduo porque o devolve a sua condição originária, entendida como unidade primigênica, em que todas as coisas estão em comunicação. A concepção positiva da morte como libertação dessas "inúteis agonias" é expressa neste outro poema de Pessanha:

Desce emfim sobre o meu coração O olvido. Irrevocável. Absoluto.

Envolve-o grave como um véu de luto.

Podes, corpo, ir dormir no teu caixão.

A fronte já sem rugas, distendidas As feições, na immortal serenidade, Dorme emfim sem desejo e sem saudade Das coisas não logradas ou perdidas.

$\mathrm{O}$ barro que em quimera modelaste Quebrou-se-te nas mãos. Viça uma flor, Pões-lhe o dedo, ei-la murcha sôbre a haste...

Ias andar, sempre fugia o chão, Até que desviravas, do terror.

Corria-te um suor, de inquietação... ${ }^{56}$

O poema causa em nós, leitores, duas impressões, a primeira é que estamos diante de um indivíduo que está morto e, por isso, agora, pode descansar em paz; a outra, talvez a mais forte e também oposta à primeira, é a sensação de inquietação, sobretudo devido ao último verso, que parece contaminar a nós, leitores. Essas duas impressões contrárias devem-se justamente ao trabalho poético empreendido por Pessanha, tanto no campo

\footnotetext{
${ }^{56}$ PESSANHA, "Desce emfim sobre o meu coração", Op. cit., p.126.
} 
semântico, como no sonoro, o que permite a simultaneidade de contrários para ir além do tradicional e dizer o que é indizível. Segundo Octavio Paz:

Há imagens que realizam o que parece ser uma impossibilidade tanto lógica quanto lingüística: as núpcias dos contrários. Em todas elas apenas perceptível ou inteiramente realizado - observa-se o mesmo processo: a pluralidade do real manifesta-se ou expressa-se como unidade última, sem que cada elemento perca sua singularidade essencial (...) $\mathrm{O}$ dizer poético diz o indizível. ${ }^{57}$

Assim, apoiando-se nessa afirmação de Paz, se pode dizer que o poema repousa sobre dissonâncias de sensações do sujeito poético e isso ocorre por meio da escolha de elementos e imagens dissonantes que, por sua vez, evocam no leitor o mesmo estado de espírito dividido entre tranqüilidade e perturbação.

A metáfora de morte, já que o sujeito diz que o olvido, isto é, o repouso desce sobre o seu coração, abre o primeiro quarteto. No segundo verso, através dos pontos finais no meio do verso, o poeta qualifica o olvido como irrevocável e absoluto e isola as duas idéias. Tendo em vista que o olvido é metáfora de morte podemos pensar que essa se caracteriza como algo que não se pode revogar; ao contrário, é soberana e toma o eu de modo absoluto, ou seja, pleno, não só o coração do sujeito, mas todo seu ser, pois nos outros versos temos a descrição das feições e da fronte tranqüilas apossadas pela morte.

A escolha pelo verbo descer é explicada pelo verso seguinte, no qual o sujeito afirma que o olvido desce sobre o seu coração e o envolve com um véu. Portanto, através dessa imagem, a morte é metaforizada pelo baixar o véu do adormecimento sobre o coração. Por isso, o sujeito pode dizer ao seu corpo que a hora de descansar "emfim" chegou; o advérbio "emfim" evidencia que a morte já era ansiada pelo sujeito. Essa analogia da morte como adormecimento faz-se presente nestes outros versos de Pessanha:

\footnotetext{
${ }^{57}$ PAZ, Op. cit., p. 49.
} 
Porque melhor, emfim,

É não ouvir nem ver...

Passarem sôbre mim

E nada me doer!

- Sorrindo interiormente,

Co' as pálpebras cerradas,

Às águas da torrente

Já tão longe passadas. -

Rixas, tumultos, lutas,

Não me fazerem dano...

Alheio às vãs labutas,

Às estações do ano.

Passar o estio, o outono,

A poda, a cava, e a redra,

E eu dormindo um sono

Debaixo de uma pedra. ${ }^{58}$

Da mesma maneira que no soneto, nesses versos, o sujeito poético deseja dormir o sono da morte, pois já se acha cansado das "vãs labutas" bem como de "rixas, tumultos e lutas". As "vãs labutas" ilustram, tal qual em "Foi um dia de inuteis agonias", a concepção da inutilidade da vida. Por isso, a morte, ao invés de aterrorizadora, é benéfica e vem possibilitar sossego ao sujeito atormentado pelas frustrações da vida.

Voltemos ao soneto. O verbo descer, que inicia o primeiro quarteto (“ Desce emfim sobre o meu coração"), relaciona-se com o caixão, última palavra da estrofe, visto que o corpo morto no caixão deve ser baixado à cova. No entanto, assim, como a imagem da morte, o caixão, objeto mórbido no qual se deposita o corpo para, assim, ser sepultado, é despojado de sua significação corrente para despontar outro significado, que o aproxima do leito de dormir, cristalizando a imagem da morte como adormecimento.

Os sons vocálicos repetidos no quarteto, a assonância das vogais /e/, /u/ e /o/, sugerem idéia de algo escuro e de morte, justamente a significação dessa estrofe, na qual o

\footnotetext{
${ }^{58}$ PESSANHA, "Porque melhor emfim", Op. cit, p.127.
} 
sujeito afirma que o corpo, defunto, pode "dormir" no caixão. Nesse mesmo quarteto, temse ainda a rima interna dos vocábulos "meu" "véu" e "teu" que criam eco que reitera o anseio de morte do sujeito poético: "meu coração", "véu de luto" e "teu caixão". Aliás, o poema contém muitas palavras com a sílaba tônica na vogal fechada e velar /u/: "meu”, "absoluto", "véu”, "luto", “teu”, "rugas", “quebrou”, murcha e "suor”. Esses vocábulos guardam o sentido do poema e o enfatizam, já que a vogal /u/ provoca a sensação em quem a articula de objetos fechados e de morte, como o caixão de que trata o primeiro quarteto.

A musicalidade é colocada a serviço do conteúdo e o enforma também: a insistência sobre tais grupos de fonemas é devida ao fato de que o som pode evocar ou acentuar imagens e sensações. Segundo Antonio Candido, "nós sentimos uma tal eficácia no efeito sonoro, que somos levados a perguntar, de novo, se no caso do signo literário, e sobretudo poético, não ocorreria uma espécie de arbítrio dentro do arbítrio" ${ }^{\text {"59 }}$. Nesse poema, bem como em muitos outros de Clepsidra, a motivação dos signos, ou seja, a relação significado/significante atinge tamanha eficácia que parece, em parte, contradizer a arbitrariedade saussuriana do signo. No entanto, o valor de escuridão e morte não se produz apenas no som da vogal, mas em toda a sonorização do tema, ou seja, na simbiose entre expressão e conteúdo. Portanto, a imagem no poema precisa das duas esferas do signo para ser suscitada, porque, apesar de aquela ser sensação visual, o apelo aos outros sentidos, sobretudo à audição, contribui para sua evocação.

Nessa primeira estrofe, temos a presença direta e íntima do sujeito poético, ilustrada pela expressão “meu coração", como se vê abaixo:

Desce emfim sobre o meu coração O olvido. Irrevocável. Absoluto.

Envolve-o grave como um véu de luto. Podes, corpo, ir dormir no teu caixão

\footnotetext{
${ }^{59}$ CANDIDO, Antonio, O estudo analítico do poema, São Paulo, Editora da FFLCH/ USP, 1967, p.29.
} 
$\mathrm{Na}$ verdade, o sujeito poético é construído no poema metonimicamente, conhecemos suas partes: coração, mãos, fronte, feições, dedo e até mesmo seu suor. O sujeito dá-se a conhecer "aos pedaços" porque as partes apresentadas representam intensamente o eu. Além disso, a composição fragmentada do sujeito poético, acentuada, também, pela sintaxe construída por frases curtas e estanques, deve-se ao fato de o Eu estar fragmentado - como já comentado anteriormente na análise de "Foi um dia de inúteis agonias”.

A elasticidade de ritmos é proporcionada por esse tipo de sintaxe utilizada nos versos em estudo: frases breves, períodos interrompidos ou deixados em suspenso. Essa sintaxe com frases estanques e os versos com certos enjambements permitem efeito rítmico inovador. O processo de liberdade rítmica, bem como o de todas as intensificações dos recursos sonoros, ilustram a importância da presença da música na poesia para os simbolistas; ilustra, além disso, a renovação métrica proposta pelo Simbolismo que culminará, mais tarde, no verso livre modernista.

Embora o poema seja um soneto petrarquiano com versos decassílabos, o poeta inova na acentuação, na cadência dos versos. Mesclam-se dois tipos de decassílabos clássicos, o heróico e o sáfico, com outros de acentuação deslocada e com acentos secundários, como podemos observar abaixo:

Desce emfim sobre o mẹu coração O olvido. Irrevocável. Absolutto.

Envolve-o grave como um véu de luto. Podes, corpo, ir dormir no teu caixão.

A fronte já sem rugas, distendidas As feiçỗes, na imortal serenidade, Dorme emfim sem desejo e sem saudade Das coisas não logradas ou perdidas. 
O barro que em quimera modelaste

Quebrou-se-te nas mãos. Viça uma flor,

Pões-lhe o dedo, ei-la murcha sôbre a haste...

Ias andar, sempre fugia o chão,

Até que desviravas, do terror.

Corria-te um suor, de inquietação...

Portanto, a musicalidade do poema é marcada, tanto pela alternância rítmica quanto pela recorrência de determinados sons. Além das assonâncias, é possível perceber a aliteração das consoantes oclusivas surdas /t, /c/ e /p/ e sonoras /d, /g/ e /b/ que imita ruído seco e repetitivo como, por exemplo, o bater de um coração. No entanto, essa repetição provoca dissonância se a aproximarmos da noção semântica do texto, visto que o coração do sujeito poético está em repouso, ou seja, não bate mais. Nesse caso a dissonância som/conteúdo, ao invés de prejudicar a significação do poema, serve para acentuar a desarmonia patente de repouso/inquietação construída pelo poeta. Outra vez são duas faces da mesma moeda. Tensão e dualidade que se completam e que não existem uma sem a outra.

A idéia da morte como adormecimento e repouso é retomada no segundo quarteto. Aliás, como podemos observar, o único verbo conjugado em todo o quarteto é "dormir", o que evidência a quietação e o sossego do sujeito poético:

A fronte já sem rugas, distendidas As feições, na imortal serenidade, Dorme emfim sem desejo e sem saudade Das coisas não logradas ou perdidas.

As rugas da fronte já não são mais visíveis, pois essa se encontra distendida. As rugas apontam para as preocupações, para as marcas do tempo passado, do que foi vivido pelo sujeito. Além disso, com a morte, as feições encontram-se "na imortal serenidade"; já que nada mais pode causar sofrimento ao indivíduo, suas expressões faciais não podem ser 
alteradas. O desejo e saudade, característicos do ser humano, modificam nosso estado de espírito continuamente e nos fazem sofrer, tais preocupações e angústias na morte deixam de existir. As imagens de morte do primeiro quarteto dada pelos vocábulos "caixão", "luto", e "olvido", e as imagens do segundo quarteto de serenidade apresentadas pela fronte sem rugas e pelo verbo dormir atuam na construção do sujeito poético que ao experimentar o estado de morto é tomado pela placidez.

A idéia da morte como ausência de sofrimento deve-se à concepção do sujeito poético de Clepsidra, para ele, a vida resume-se na decepção e na inutilidade de esforços; logo, o único caminho possível é a desistência e a resignação. Segundo Franchetti, esse é o "tom específico de Pessanha que a partir da experiência da decepção vai propagando imagens de quietação, da ausência do desejo, da morte que constituem o tecido simbólico mais característico de Clepsidra" ${ }^{60}$. No poema em análise, deparamo-nos com o ápice da passividade e da inação, já que o sujeito encontra-se morto. Não há nem mesmo a ação passiva de contemplar a realidade, que é decepcionante, pois se resume em "coisas não logradas ou perdidas". De fato, como afirma Seabra Pereira, a noção de passividade e aniquilação dos desejos é constante na poesia finissecular:

A aniquilação do sentir parece na poesia decadentista, o necessário caminho para abrandar a ulceração do ser humano, causada pela vibração infrutífera do amor, pela desgraça, pela agitação vã do espírito confiante ou pela angústia de mergulhar na complexidade do próprio íntimo ${ }^{61}$.

Devido a essa concepção da vida, presente no soneto em estudo, "Desce emfim sobre o meu coração", o advérbio "emfim", que aparece no primeiro verso desta composição, é repetido no sétimo, para enfatizar que, como a existência é dolorosa, a morte é esperada, ou, mais que isso, ansiada, pois emerge como libertação dos sofrimentos

\footnotetext{
${ }^{60}$ FRANCHETTI, Paulo Elias Allane, Nostalgia, Exílio e Melancolia, São Paulo, Edusp, 2001, p. 92.

${ }^{61}$ SEABRA PEREIRA, Op. cit., p. 278.
} 
do eu. Viver no mundo é experiência trágica e dolorosa à qual a morte põe um fim, ou, utilizando-se das próprias palavras do sujeito poético, a morte é o estado mais feliz no qual o indivíduo é libertado do desejo "das coisas não logradas ou perdidas". Nesse estado de morto do sujeito poético, desaparece todo o sofrimento, como sugerem as feições que estão na "imortal serenidade". De acordo com Schopenhauer:

até aqui o que resulta é que a morte, por mais temida que seja, não pode ser propriamente mal algum. Muitas vezes ela aparece como um bem desejado, como uma amiga bem vinda. Qualquer um que se deparou com obstáculos intransponíveis para sua existência ou para suas aspirações, que sofria doenças incuráveis, ou desgostos inconsoláveis, tem como último refúgio, que muitas vezes se oferece por si mesmo o retorno ao ventre da natureza, do qual, como também toda outra coisa, por breve tempo emergira, seduzido pela esperança de condições mais propícias de existência do que as aí encontradas, e a partir da qual, o mesmo caminho de saída sempre lhe permanece aberto. Esse retorno é a cessuo bonorum. ${ }^{62}$

Portanto, como afirma Schopenhauer, o sofrer e a dor são intrínsecos à existência do ser humano. Essa idéia, que perpassa todo o poema, está presente também nestes versos, nos quais se afirma que a ausência de dor é também ausência de vida:

Porque a dôr, esta falta de harmonia,

Toda luz desgrenhada que allumia

As almas doidamente, o ceo d'agora,

Sem ella o coração é quase nada:

- Um sol onde expirasse a madrugada,

Porque é só madrugada quando chora. ${ }^{63}$

Nesses versos, o poeta utiliza-se de uma maneira indireta de dizer que tudo é dor, que seu coração é somente dor. A imagem da madrugada ligada ao choro, ou seja a idéia de dor, evoca o terceto anterior, já que a dor é comparada às luzes irregulares,

\footnotetext{
${ }^{62}$ SCHOPENHAUER, Arthur, Metafísica do Amor/Metafísica da Morte, (Trad. Jair Barbosa), São Paulo, Martins Fontes [s/d], p. 71.

${ }^{63}$ PESSANHA, "Tenho sonhos cruéis: n'alma doente", Op. cit., p.80.
} 
possivelmente, vindas das estrelas, que existem na madrugada. O poeta, ao dizer que só é madrugada quando chora, substitui a definicão de dor, apresentada nos versos do primeiro terceto ("esta falta de harmonia/Toda luz desgrenhada que allumia/As almas doidamente, o ceo d'agora") pelo verbo chorar, que expressa dor e tristeza. Assim, sem dor não há coração, como sem luzes irregulares, as estrelas, não existe madrugada. Essa perspectiva da dor indissociável do indivíduo é apresentada também pelo soneto "Desce emfim sobre o meu coração", pois o coração, métafora do sujeito poético, só pode libertar-se da dor por meio do olvido, ou seja, por meio da morte.

Voltemos ao poema "Desce enfim sobre o meu coração", deixado em suspenso. No primeiro terceto, o sujeito evoca imagens que indicam a transitoriedade da vida:

O barro que em quimera modelaste Quebrou-se-te nas mãos. Viça uma flor, Põe-lhe o dedo, ei-la murcha sôbre a haste...

O "modelar o barro em quimera" alude à fragilidade e ao caráter vão dos sonhos projetados pelo sujeito, os quais, como ele sugere, não foram concretizados, mas quebraram-se e perderam-se. Já a flor que murcha é representação da efemeridade das coisas frente ao fluir inexorável do tempo, ela é tão efêmera que basta um toque para murchá-la. A fugacidade dos sonhos e da vida é indicada, no campo sonoro, pela aliteração das sibilantes que apontam o esvair de algo, que pode ser o tempo, ou ainda, o esmorecimento e dissipação do próprio indivíduo, noção semântica de todo poema.

É interessante notar a oposição entre o tempo do indivíduo, que é lento, demonstrado pelo advérbio "enfim", que aparece, como anteriormente notado, duas vezes, e o tempo breve das coisas, simbolizado pelo tempo da flor. Essa perspectiva temporal é 
construída, sem dúvida, pelo desencanto do sujeito poético com a realidade, que se resume à "coisas não logradas "ou perdidas" e pelo desejo constante de morte.

O indivíduo tem de esperar o transcorrer do tempo de toda a sua existência para "emfim", morrer, e experimentar esse total estado de felicidade, enquanto a flor, rapidamente, viça e murcha. A espera pelo sereno repouso é dolorosa e cansativa para o sujeito, pois ele tem certo afrouxamento da noção temporal; esse descompasso do eu em relação ao tempo em que está inserido deve-se a sua inadaptação à realidade circundante, aos novos valores do mundo moderno. Tal idéia é expressa no último terceto:

Ias andar, sempre fugia o chão, Até que desviravas, do terror.

Corria-te um suor, de inquietação...

O advérbio "sempre" ajuda na construção do sujeito poético como inadequado na medida em que intensifica esse desajuste, já que mostra um sujeito que, em momento algum, encontra lugar para si no mundo, ao contrário, ao, imbolizado, observar a realidade a perdia de vista e desvairecia, quer dizer, desorientava-se. O sentimento difuso de inquietação que este sujeito experimentava em vida é comum no final dos Oitocentos, conseqüência do estado irreversível de decadência de toda Europa. Na verdade, o progresso e as novas tecnologias não resolveram as dúvidas metafísicas, a que afligiam o homem, como comentado anteriormente, porém só destruíram antigos valores, fazendo-o experimentar intenso sentimento de crise e angústia

Os tercetos do soneto opõem-se aos quartetos, quer pela escolha lexical, quer pela pontuação - os versos finais terminam em reticências, que indicam que o tom grave, sereno e tranqüilo dos quartetos desaparece e sobressai a angústia. A ausência de movimento ou, ainda, do passar do tempo, já que os verbos dos quartetos encontram-se no presente, 
sugerindo atemporalidade, cede lugar a verbos cujos tempos verbais indicam ação no passado e passagem do tempo. Além disso, "o suor de inquietação" é algo essencialmente de quem se encontra vivo e absolutamente oposto à imagem de tranqüilidade e serenidade dos quartetos. Assim, a imagem do presente, fixa, permanente, serena, do cadáver com as "feições distendidas", que não podem ser mudadas, cede lugar ao passado, marcado pelo passar das coisas, noção sugerida pela efemeridade da flor, e por um sujeito absolutamente agitado. Essa justaposição de imagens enfatiza o sofrimento do sujeito em vida e sua felicidade plena experimentada na morte. Os quartetos que apresentam a noção de tranqüilidade referem-se ao presente, no qual o sujeito encontra-se já tomado pela morte, enquanto os tercetos tratam do passado, tempo de sofrimento do Eu.

Não por acaso, a derradeira palavra do último verso, "inquietação", deixado em suspenso por meio de reticências, cria certa expectativa, que não é resolvida. Ao chegarmos ao fim da leitura, a inquietação parece tomar conta de nós; assim, o poeta demonstra que tal sentimento é parte da condição humana e que apenas na morte é possível esvaziar-se de todos os pensamentos que perturbam e "enfim" quietar-se - o que remete para o início do poema: "Desce emfim sobre o meu coração" é o anseio do eu inquieto, que somente tem paz no esquecimento e apaziguamento propiciado pela morte. Se essa leitura procede, o poema pode ser considerado numa perspectiva cíclica, de fim e recomeço, pois, na conjuntura poética simbolista, ao eu inquieto, dorido, sofrido, não resta saída melhor que descer o coração ao olvido. 


\section{CAPÍtULO IV - PAUL VERLAINE E CAMILO PESSANHA EM PERSPECTIVA DIALOGADA - CONVERGÊNCIAS E DIVERGÊNCIAS}

Como temos visto, o fluir inexorável do Tempo constitui-se nas obras de Paul Verlaine e Camilo Pessanha como Leit motiv. Os títulos Jadis et Naguère e Clepsidra contém a noção de Tempo; Clepsidra é um tipo de ampulheta movida à água; logo, podemos perceber, mesmo antes da leitura da obra, que o Tempo é concebido como algo que, da mesma maneira que a água, escoa continuamente. Jadis e Naguère são advérbios temporais que podemos entender respectivamente como "outrora" e "há pouco", ou seja, expressam um período de tempo compreendido entre um passado distante e um passado breve. Já Poèmes Saturniens não apresentam no título nenhuma referência direta ao tempo; no entanto, em seu interior, nos poemas, como já demonstrado, há um sujeito que, dominado pela melancolia e pelo tédio e vivendo sob a influência de Saturno sente as coisas passarem lentamente.

Não por acaso, nas obras de Paul Verlaine e Camilo Pessanha, os elementos símbolos do tempo e da fugacidade das coisas ou o tormento do sujeito poético causado pela passagem daquele são freqüentes. Os objetos chamados de memento mori, como a ampulheta, a flor e a caveira, são recorrentes nos poemas. Algumas vezes, esses elementos não aparecem explicitamente, mas há símiles como a clepsidra, a natureza e o cadáver, respectivamente.

A relação do sujeito poético das obras citadas com o tempo é fundamental e configura-se a partir da consciência daquele em crise com a realidade. A sensibilidade poética finissecular filtra a filosofia pessimista de Schopenhauer que coincide com a disposição decadentista: atitude desistente e prostrada; desejo de aniquilação e visão da

morte como libertação. Por isso, a morte é recorrente nos poemas finisseculares, 
expressando o desejo de aniquilação de um indivíduo, como demonstram estes versos de Pessanha que abrem Clepsidra:

Eu vi a luz em um paiz perdido.

A minha alma é lânguida e inerme.

Oh! Quem pudesse deslizar sem ruído!

No chão sumir-se como faz um verme... ${ }^{64}$

O descompasso entre a percepção temporal do indivíduo e o tempo do mundo é experimentado apenas pelo sujeito poético: ainda que a industrialização, a invenção do relógio e a associação dele ao tempo de produção tenham acelerado a vida na modernidade, tudo está no seu curso normal, é o eu que tem a visão "distorcida" da realidade e não se adapta a esse novo modo de se relacionar com o mundo, com as coisas, com o processo de execução de tarefa e com o tempo despendido para isso. O tempo psicológico do eu difere-se do tempo cronológico; segundo a filosofia Kantiana, esse conflito ocorre porque o tempo é abstrato e sempre subjetivado, de modo que existe apenas dentro do próprio sujeito que, por sua vez, transfere seu próprio tempo para os objetos exteriores:

O tempo não é um conceito empírico, derivado de qualquer experiência (...) o tempo não passa, pois de uma condição subjetiva da nossa (humana) intuição (a qual é sempre sensível, isto é, implica que nos somos afetados pelos objetos), e nada é, em si mesmo fora do sujeito" ${ }^{\text {"65 }}$

Assim, tudo ao redor do Eu está em perene movimento enquanto ele adota postura estática, permanecendo à distância, à margem, apenas contemplando o tempo passar. Esse descompasso é expresso nesta estância de outro poema de Pessanha, no qual o sujeito poético é alguém desencantado e entediado porque o tempo passa e não o leva consigo:

\footnotetext{
${ }^{64}$ PESSANHA, "Inscrição", in Op. cit, p.75.

${ }^{65}$ KANT, Emmanuel, Crítica da Razão Pura, p. 109, citado por Encilopédia Einaud, p. 44.
} 
Imagens que passaes pela retina

Dos meus olhos, porque não vos fixaes?

Que passaes como água cristalina

Por uma fonte para nunca mais!...

Ou para o lago escuro onde termina

Vosso curso, silente de juncaes,

E o vago medo angustioso domina,

- Porque ides sem mim, não me levaes? ? $^{66}$

Nesses versos, estamos diante de um sujeito que contempla as imagens à distância, mas elas não se fixam na sua mente, apenas passam pela retina, visto que seus olhos são "espelhos inúteis". Dessa maneira, o presente resume-se ao drama da captação do inefável, a apreensão da fugacidade das coisas. Portanto, a atitude de desistência e passividade do Eu é fruto desse pessimismo que o faz "encarar" a vida absolutamente como sofrimento. Nessa perspectiva, o presente, o passado e o futuro se igualam, pois as limitações de tempo desconfiguram-se na mente do sujeito, já que a sensação de sofrimento e desajuste no mundo é constante e independente do tempo cronológico. Por isso, o sujeito poético sente seu tempo, interiorizado e subjetivado, passar mais lento se comparado ao tempo exterior, cronológico e objetivado; por conseguinte, deseja ser levado juntamente com as imagens que passam diante dos seus olhos. Devido à impossibilidade de aceleração de tal processo, ele interroga as próprias imagens: "Porque ides sem mim, não me levais?”.

A atitude de aniquilação, o desejo de se deixar passar como "feuille morte" é fruto da melancolia e do tédio de um sujeito cansado da realidade circundante, que se reflete na maneira que este concebe o tempo. Assim, o cansaço do homem finissecular, seu "desencanto" e "des-engano" aparecem nas obras de Verlaine e Pessanha ligados à perspectiva temporal do sujeito. Nos versos de "Langueur" é possível perceber tal relação:

\footnotetext{
${ }^{66}$ PESSANHA, Op. Cit., p. 102.
} 


\section{Langueur}

A Georges Courteline.

Je suis l'empire à la fin de la décadence,

Qui regarde passer les grands Barbares blancs

En composant des acrostiches indolents

D'un style d'or où la langueur du soleil danse.

L'âme suellete a mal au coeur d'un ennui dense.

Là-bas on dit qu'il est des longs combats sanglants.

O n'y pouvoir, étant si faible aux voeux si lents,

O n'y vouloir fleurir un peu cette existence!

O n'y vouloir, ô n'y pouvoir mourrir un peu!

$\mathrm{Ah}$ ! tout est bu! Bathylle, as-tu fini de rire?

$\mathrm{Ah}$ ! tout est bu, tout est mangé! Plus rien à dire.

Seul, un poème um peu niais, qu'on jette au feu, Seul, un esclave um peu coureur qui vous néglige, Seul, un ennui d'on ne sait quoi qui vous afflige! ${ }^{67}$

A leitura do poema de Verlaine provoca aguda sensação de angústia e tédio. Ao lê-lo nos deparamos com um sujeito poético em profunda crise com a sociedade em que vive, de modo que esse sentimento se exterioriza e chega até o leitor. Já no título do poema, nos é apresentada a situação do sujeito poético que está tomado pelo sentimento de "langueur" (langor), o qual é desenvolvido no poema. Sobre o langor, Franchetti afirma que é topos da poesia finissecular, caracterizando-se pela oscilação entre vários estados de alma, como atonia, volúpia, morbidez e definhamento. Portanto, o indivíduo apresenta tais características:

fecha-se em si mesmo, embebe-se da sensação de tédio e assim resiste afirmando sua oposição a tudo que o rodeia, mas como se sente enfraquecido deseja fortemente evadir-se da situação de confronto que parece suportar ${ }^{68}$.

\footnotetext{
${ }^{67}$ VERLAINE, "Langueur", Jadis et Naguère, p. 83.

${ }^{68}$ FRANCHETTI,Paulo Elias Allane, Nostalgia, Exílio e Melancolia, São Paulo, Edusp, 2001, p. 35.
} 
Percebemos que esse sentimento e suas conseqüências vão sendo desenvolvidos de maneira bem explícita no decorrer do poema, ajudando na formação do sujeito poético desencantado e, sobretudo, desajustado do mundo que o rodeia, pois ele não participa do que acontece, apenas observa como ele mesmo enfatiza com o verbo "regarder" (olhar).

Nos dois primeiros versos, temos a metáfora imagética do indivíduo que se sente como o império no fim da decadência que olha alheio os grandes bárbaros passarem ("Je suis l'empire à la fin de la décadence / Qui regarde passer les grands Barbares blancs"). Não há nada que se possa fazer para mudar a situação de abatimento, a metáfora do império mostra todo o mal-estar do sujeito poético que afirma que o império além de decadente, assim como ele, encontra-se no final de um processo, “à la fin de la décadence". Esse paroxismo da existência, no qual as coisas tendem a desaparecer enquanto o eu adota postura passiva, é acentuado pela inação do sujeito poético que tem de esperar o transcorrer do tempo, pois não há possibilidade de libertação. O léxico do poema por meio dos vocábulos “décadence” (decadência), "indolent”(indolente), "seulete”(sozinha), "ennui dense"(tédio denso), "faible"(fraco) desenvolve o langor apontado pelo título e atua na composição, verso a verso, do estado de decadente do sujeito poético.

O sentimento de decadência, como anteriormente comentado no primeiro capítulo, é forte no final o século XIX e recorrente na poesia simbolista, visto que o indivíduo sente-se em crise com o mundo em que vive, pois não acha lugar nele. Esse estado de inadaptação reduz o eu à inação, de modo que o sujeito poético não tem forças para reagir, assim como o império que está acabando. Sem dúvida, como mostrado no primeiro capítulo, no caso Francês, o sentimento de decadência, além de estar relacionado com as crenças do fim do século e com as desilusões vindas da confiança na ciência, somase à derrota francesa na guerra prussiana. 
O sujeito poético sente-se inadequado em relação ao mundo moderno, que está tomado por modificações sociais que ocorreram no século XIX, do mesmo modo que o império (francês) está tomado pelos grandes bárbaros (prussianos), "les grands Barbares blancs". Devido à desilusão com a realidade, ele apenas olha o que está acontecendo ao seu redor, guarda distância das coisas, assumindo atitude de passividade e inação, comum na poesia verlainiana, como afirma o crítico Jean Pierre Richard

en face des choses l'être verlainien adopte spontanément une attitude de passivité, d'attente. Vers leur lointain inconnu il ne projette pas sa curiosité, ni son désir, il ne tente même pas de les dévoiler (...) Il demure immobile e tranquille" ${ }^{69}$.

Enquanto o sujeito poético vê os bárbaros passarem e a languidez do sol refletir sobre eles, ele, a distância, compõe "acrostiches indolents" (acrósticos indolentes). Lembremo-nos dos versos:

Je suis l'empire à la fin de la décadence,

Qui regarde passer les grands Barbares blancs

En composant des acrostiches indolents

D'un style d'or où la langueur du soleil danse.

O acróstico é um tipo de composição poética, na qual o conjunto de letras, geralmente iniciais, compõe verticalmente uma frase ou palavra. Os acrósticos, compostos pelo sujeito poético são indolentes e possuem "un style d'or" (estilo de ouro). A evocação da imagem do sujeito fazendo poesia é absolutamente oposta à imagem dos bárbaros que são incivilizados; essa dissonância enfatiza a relação de afastamento do sujeito poético com o mundo.

\footnotetext{
${ }^{69}$ RICHARD, Op. Cit, p.165: "Diante das coisas o ser verlainiano adota espontaneamente uma atitude de passividade, de espera. Ele não projeta sua curiosidade, nem seu desejo, para o desconhecido, ele não tenta nem mesmo descobri-los. Ele permanece imóvel e tranqüilo".
} 
Em "Langueur", como não podia deixar de ser, significado e significante correspondem-se. Os dois quartetos são marcados pela aliteração da nasal /n/ que corrobora a sensação de langor, auxiliando na construção do sujeito poético sem forças. Os sons nasais abundantes nos quartetos criam um ritmo "mole", mas contínuo, que se assemelha à passagem dos bárbaros brancos, ou ainda, à passagem do tempo que tortura o sujeito poético, como mostram as estâncias:

Je suis l'empire à la fin de la décadence, Qui regarde passer les grands Barbares blancs En composant des acrostiches indolents

D'un style d'or où la langueur du soleil danse.

L'âme suellete a mal au coeur d'un ennui dense.

Là-bas on dit qu'il est des longs combats sanglants.

O n'y pouvoir, étant si faible aux voeux si lents,

O n'y vouloir fleurir un peu cette existence!

A musicalidade dos versos está associada às camadas significativas do poema. Enquanto os quartetos são marcados pela aliteração, os tercetos caracterizam-se pela assonância das vogais "e" e "ai" que tem som de /e/ e /é/ respectivamente, e da vogal /i/. Esses sons vocálicos mais agudos sugerem o sentimento de dor e angústia do sujeito poético, como podemos notar nos versos:

O n'y vouloir, ô n'y pouvoir mourrir un peu!

$\mathrm{Ah}$ ! tout est bu! Bathylle, as-tu fini de rire?

$\mathrm{Ah}$ ! tout est bu, tout est mangé! Plus rien à dire.

Seul, un poème um peu niais, qu'on jette au feu, Seul, un esclave um peu coureur qui vous néglige, Seul, un ennui d'on ne sait quoi qui vous afflige! ${ }^{70}$

\footnotetext{
${ }^{70}$ VERLAINE, "Langueur”, Jadis et Naguère, p. 83.
} 
A música do poema deriva também do ritmo "simbolista" dos versos, pois, apesar do poema ser um soneto, ele é composto por versos alexandrinos trímetros, acentuados na $4^{\mathrm{a}}, 8^{\mathrm{a}}$, e $12^{\mathrm{a}}$ sílabas poéticas.

No último verso da primeira estrofe (“D'un style d'or où la langueur du soleil danse"), repete-se o vocábulo "langueur" do título. Nessa estância, o sujeito caracteriza os raios solares como langorosos; ora, o langor é um sentimento humano que o poeta transfere para o sol. Como visto anteriormente no capítulo dedicado a Verlaine, as representações externas auxiliam na construção do íntimo do sujeito poético, já que o externo reflete o estado interior, que está langoroso, e, por isso, este sente langor no sol.

A idéia de tédio e desencanto é reforçada pelo segundo quarteto, principalmente pelo primeiro verso, como podemos observar:

L'âme suellete a mal au coeur d'un ennui dense.

Là-bas on dit qu'il est des longs combats sanglants.

O n'y pouvoir, étant si faible aux voeux si lents,

O n'y vouloir fleurir un peu cette existence!

O sujeito poético recolhido em si mesmo consegue perceber sua alma e seu coração. A alma e o coração representam o que há de mais íntimo no Eu, suas emoções e sensações íntimas. No soneto, há um movimento recorrente do externo, por exemplo, dos bárbaros, para o íntimo do eu, sua alma, seu coração. É no século XIX que a Poesia Intimista, cuja base é a sensação e a emoção íntima do sujeito transpostas para o papel, desenvolve-se de maneira mais profícua, pois o sujeito desencantado com o externo voltase para o seu íntimo e volta-se, também, para buscar-se a si mesmo, para saber-se ontologicamente. Embora em "Langueur" o mergulho íntimo e a análise de si mesmo sejam bem explícitos, em muitos poemas de Verlaine o intimismo mistura-se ao impressionismo e é preciso, como foi visto em "Allégorie", perceber a contrução do sujeito 
por trás da descrição das paisagens. Já nos poemas de Pessanha, o Eu é figura central e explícita na maior parte dos poemas; constantemente, como nestes versos abaixo, o poema trata de expressar o mal-estar íntimo do sujeito poético:

Tenho sonhos cruéis: n'alma doente.

Sinto um vago receio prematuro

Vou a medo na aresta do futuro,

Embebido em saudades do presente ${ }^{71}$

Voltemos ao soneto "Langueur". No primeiro verso do segundo quarteto "L'âme suellete a mal au coeur d'un ennui dense", o ennui, sentimento que invade o íntimo do sujeito poético, e que pode ser traduzido por tédio, está intimamente relacionado ao desencanto com a realidade e a noção de tempo. Segundo Balakian, o ennui pode ser definido como o "cansaço do homem super refinado e a impossibilidade de libertação ${ }^{72 "}$.

A repetição de versos e palavras no poema é recurso estilístico que enfatiza o sentimento de tédio e angústia desenvolvido pelo conteúdo. Repete-se os verbos "vouloir" e "pouvoir" e o adjetivo "seul”, como podemos observar abaixo:

O n'y pouvoir, étant si faible aux voeux si lents,

O n'y vouloir fleurir un peu cette existence!

n'y vouloir, ô n'y pouvoir mourrir um peu!

$\mathrm{Ah}$ ! tout est bu! Bathylle, as-tu fini de rire?

! tout est bu, tout est mangé! Plus rien à dire.

Seul, un poème un peu niais, qu'on jette au feu, Seul, un esclave un peu coureur qui vous néglige, Seul, un ennui d'on ne sait quoi qui vous afflige!

A desilusão e o desgosto do sujeito poético com o mundo geram o sentimento de tédio que aparece em muitos outros poemas de Verlaine e de Camilo Pessanha. Devido ao

\footnotetext{
${ }^{71}$ PESSANHA, "Tenho sonhos cruéis n'alma doente", Op. cit., p. 80

${ }^{72}$ BALAKIAN, Anna, O Simbolismo, São Paulo, Ed. Perspectiva, 1995, p. 64.
} 
desencanto e ao tédio do mundo exterior, o sujeito poético distancia-se e fica alheio à realidade, como afirma os versos de "Langueur":

Là-bas on dit qu'il est des longs combats sanglants.

O n'y pouvoir, étant si faible aux voeux si lents,

O n'y vouloir fleurir un peu cette existence!

O n’y vouloir, ô n'y pouvoir mourrir un peu!

O advérbio "Là-bas" (distante) enfatiza a distância que o eu guarda da realidade. O sujeito poético se confessa "faible", sem forças para enfrentar "les combats sangrants" (os combates sangrentos), os quais podem ser metáfora da vida, definida como negativa e carregada de sofrimento, como sugere o vocábulo "sanglants" (sangrentos).

Nos últimos dois versos do quarteto e no primeiro verso do terceto, há um jogo semântico e sonoro entre os verbos “pouvoir" e "vouloir”. O jogo é causado pela rima interna dos versos e pela estrutura semelhante deles. Percebemos que não há a negação dupla, ou seja, a outra partícula da negação - o pas - está ausente. Poucos verbos franceses permitem que na negação o ne apareça sozinho, entre eles estão os verbos "vouloir" e "pouvoir". Omitir a partícula pas é questão de elegância no uso da língua. Nesses versos, além dessa questão percebemos que pas é omitido também porque, caso aparecesse, quebraria a sonoridade e a cadência dos versos.

O sujeito poético é construído no decorrer do poema como indivíduo que não pode e não quer sair da situação em que se encontra. Na verdade, ele não tem força para reagir, como sugere o verso "O n'y vouloir fleurir un peu cette existence", e nem para morrer como confirma o verso seguinte "O n’y vouloir, ô n'y pouvoir mourrir un peu”. O cansaço da vida leva à inação do sujeito poético, que tem de esperar o transcorrer do tempo, pois a única possibilidade de libertação é através da morte. A sensação de desencanto, de vazio das 
coisas e também de vazio interior, causa paralisia no Eu. Para Michaud, essa atitude é comum nos sujeitos poéticos tomados pelo spleen, ou em francês pelo ennui; segundo o crítico, "Le spleen est une sorte de violence immobile". ${ }^{73}$

Tendo em vista o sofrimento e a frustração, o sujeito poético de "Langueur", afirma que não há mais nada a ser feito:

Ah! tout est bu! Bathylle, as-tu fini de rire?

$\mathrm{Ah}$ ! tout est bu, tout est mangé! Plus rien à dire

Os verbos comer e beber são ações ligadas à sobrevivência humana, ou seja, são ações mínimas que todo o homem precisa fazer para viver. No poema, as constatações "tout est bu" e "tout est mangé", significam que tudo o que poderia ser feito já o foi e não há como mudar a realidade decepcionante, por isso, todo esforço é vão, como ilustram bem estes versos de outro poema de Verlaine, "Les Vaincus":

Ah! Puisque notre sort est bien complet, qu'enfim

L'espoir est aboli, la défaite certaine,

Et que l'éffor le plus énorme serait vain,

Et puisque c'en est fait, même de notre haine, ${ }^{74}$

O sentimento de decadência e de frustração é tão forte que o sujeito já se sente como derrotado e em vias de se extinguir; não há mais nenhuma esperança em voltar a ter momentos bons, por isso todas as ações são inúteis.

Quanto ao nome "Batylle", que aparece no segundo verso do primeiro terceto de "Langueur" pode ser referência ao poeta latino, em português, Bátilo que reivindicou a autoria de certos versos de Virgílio. Se olharmos estes versos de Virgílio, notamos que eles

\footnotetext{
${ }^{73}$ MICHAUD, Message poétique Du Symbolisme, p. 52.

${ }^{74}$ VERLAINE, "Les Vaincus", in Jadis et Naguère, p. 77.
} 
possuem a mesma estrutura do terceto final do soneto de Verlaine e a primeira sílaba "s" é repetida nos dois poemas:

Sic vos non vobis, nidificatis, aves!

Sic vos non vobis, vellera fertis, oves!

Sic vos non vobis, mellificates, apes !

Sic vos non vobis, fertis aratra, boves $!^{75}$

Seul, um poème um peu niais, qu'on jette au feu,

Seul, um esclave um peu coureur qui vous néglige,

Seul, um ennui d'on ne sait quoi qui vous afflige!

Outra hipótese plausível seria que "Bathylle" faz referência ao poema erótico "Bathylle" de Jean Lorrain, publicado na revista Le Chat Noir em 1882, um ano antes da publicação do poema de Verlaine. Segue abaixo o poema de Lorrain:

Bathyle

Au fond d'un bouge obscur, où boivent des marins, Bathyle, le beau Thrace aux bras sveltes et pâles, Danse au bruit de la flûte et des gais tambourins. Ses pieds fins et nerveux font claquer sur les dalles

Leurs talons teints de pourpre, où sonnent des crotales, Et, tandis qu'il effeuille en fuyant brins à brins Des roses, comme un lys entr'ouvrant ses pétales, Sa tunique s'écarte aux rondeurs de ses reins.

Sa tunique s'écarte et la blancheur sereine De son ventre apparaît sous sa toison d'ébène. Bathyle alors s'arrête et, d'un oeil inhumain

Fixant les matelots rouges de convoitise,

75 VIRGILIO, citado por MENDES, Mauro, Virgílio e os Cantadores, p.02, disponível em WWW.cronopios.com.br/anexos/virgílio mauromendes, em 12 de maio de 2008. Em tradução livre: "Não para vós, construís o ninho, ó aves/não para vós, fabricais a lã, ó ovelhas!/não para vós fabricais o mel, ó abelhas!/não para vós, puxais o arado, ó bois!"” 
Il partage à chacun son bouquet de cythise

Et tend à leurs baisers la paume de sa main. ${ }^{76}$

O poema de Jean Lorrain faz parte do conjunto de três poemas denominados "Le Éphèbes", assim, nos versos o belo efebo denominado Bathylle dança atiçando a cobiça dos marinheiros. O poema de Verlaine, ao fazer referência ao de Lorrain, pode estar querendo se referir que a alegria, simbolizada pela dança do efebo da Grécia antiga, não tem mais lugar na nova sociedade.

Voltemos ao poema "Langueur". No último terceto, aparece o estado de solidão no qual o sujeito poético se encontra imerso e, conseqüentemente, seu recolhimento frente ao mundo, através da anáfora do termo "seul", que reitera o estar só. A solidão é condição fundamental para o ensimesmamento; estando sozinho, o indivíduo consegue desviar o olhar do externo e permanecer concentrado em si mesmo.

Lemos, nesses versos, que o poema é jogado ao fogo, pois se tornou "niais", tolo, de modo que a voz do poeta, que é o poema, não tem ação sobre a sociedade. Portanto, esses versos ilustram a ruptura do poeta com os esquemas mentais, com os valores sociais e comportamentais do mundo em que está inserido. É a rejeição plena à reificação - tão comum nesse fim de Oitocentos.

No último verso, temos a repetição do ennui, contudo o sujeito poético confessa que não sabe exatamente o que provoca esse sentimento. Não há algo preciso que provoque o sentimento de crise no sujeito poético, na verdade, é toda sua existência: a sociedade da reificação, a transitoriedade e ao mesmo tempo o cansaço da espera, enfim, os novos valores do mundo moderno. Esse sentimento indefinido do interior do sujeito contamina o exterior, como expressam esses versos de Pessanha:

\footnotetext{
${ }^{76}$ LORRAIN, "Bathylle", disponível em www.poesie-érotique.net/JeanLorrain , em 18 de agosto de 2008.
} 
É este enlanguecer da natureza,

Este vago soffrer do fim do dia. ${ }^{77}$

Tristeza indefinida assim como o poente, tristeza que o sujeito poético sente e não sabe exatamente de onde vêm parece-nos justamente expressa na epígrafe apensa ao poema "Meus olhos apagados", de Camilo Pessanha. Leiamo-lo:

\section{Il pleure dans mon coeur Comme il pleut sur la ville Verlaine.}

Meus olhos apagados,

Vede a água cahir.

Das beiras dos telhados,

Cahir, sempre cahir.

Das beiras dos telhados,

Cahir, quasi morrer...

Meus olhos apagados,

E cançados de ver.

Meus olhos, afogae-vos

Na vã tristeza ambiente.

Cahi e derramae-vos

Como a água morrente. ${ }^{78}$

Na epígrafe de Verlaine, além da relação semântica através da qual o poeta associa a chuva que cai na cidade ao choro, ou seja, às lágrimas "do seu coração", percebemos que há também jogo sonoro com os verbos "pleurer" et "plevoir". Esses recursos contribuem para a noção de que o sujeito poético está imerso numa sensação de melancolia e tristeza e não sabe exatamente porque sofre, pois na verdade, toda a sua existência é sofrimento, por isso, o choro é algo tão natural como a chuva que cai.

Em linhas gerais, poema de Pessanha tematiza um sujeito que fica contemplando a chuva que cai dos telhados. Embora formalmente muito diferente do poema "Langueur" de

\footnotetext{
${ }^{77}$ PESSANHA, "Crepuscular”, Op. Cit., p. 83.

${ }^{78}$ Ibidem, "Meus olhos apagados", p.92.
} 
Verlaine, causa no leitor a mesma sensação de angústia e tédio. Os dois poetas utilizam-se de elementos formais diferentes para construir o sujeito poético desencantado e entediado que se recolhe em si mesmo enquanto o tempo passa; por isso, ambos conseguem produzir o mesmo efeito de angústia no leitor.

A forma utilizada por Verlaine é mais clássica, visto que é um soneto com versos alexandrinos. Em "Meus olhos apagados", temos três quartetos com seis sílabas poéticas em cada verso; o ritmo no poema é bem marcado, as sílabas poéticas acentuadas são as $2^{\mathrm{a}} \mathrm{e}$ $6^{\mathrm{a}}$ nos versos ímpares e as $3^{\mathrm{a}}$ e $6^{\mathrm{a}}$ nos versos pares. Essa acentuação contínua, em versos curtos, imita a cadência do pingo de água que escorre do telhado e cai no chão. Os enjambements contribuem para o "escorregar" dos versos: a forma do poema, contínua e fluida, assemelha-se a água que se derrama, como mostram os versos da primeira estrofe:

Meus olhos apagados,

Vede a água cahir.

Das beiras dos telhados,

Cahir, sempre cahir.

As aliterações presentes no poema contribuem para a questão semântica. A aliteração da sibilante /s/ imita o barulho da chuva e aliteração da líquida /l/ dá a sensação de molhado, de água que escorre. Esses recursos reproduzem a liquidez e fluidez da água da chuva e também do tempo.

De fato, o poema de Pessanha é extremamente musical. Os efeitos musicais, segundo Álvaro Cardoso Gomes, "visam a criar sucedâneos da duração ${ }^{79}$ ", ou seja, a música cria imagens de permanência. Nesse poema, podemos ver dois métodos diferentes para relacionar poesia e música, um deles característico de Verlaine e outro de Mallarmé.

As repetições de versos e palavras causam efeito visual e tonal no poema. Para

\footnotetext{
${ }^{79}$ GOMES, Op. cit. , p. 165.
} 
Mallarmé, a poesia deve simular uma sinfonia e, assim, diminuir o grau de descontinuidade entre uma mudança e outra. Portanto, as repetições de palavras e versos do poema dão certa continuidade às estrofes que se organizam e fluem como uma sinfonia. Já o apelo ao ouvido, isto é, as repetições de sons idênticos ou semelhantes, é recurso muito utilizado por Verlaine. Nesse caso, a continuidade é sugerida pela alternância de sons idênticos e semelhantes, tal método pode ser percebido no poema em estudo pelas aliterações.

A água na poética de Pessanha é elemento constante e aparece das mais variadas formas: chuva, mar, rio, fonte etc. Embora ela tenha várias simbologias, a mais marcante, a nosso ver, é a água como metáfora de tempo, pois é a projeção no plano fônico e visual do fluir inexorável do tempo. Essa relação tempo/ água aparece já no título da obra de Pessanha, visto que Clepsidra é, como já foi mencionado, ampulheta movida à água. Como podemos perceber nos versos, a água pode marcar o passar do tempo exterior em oposição ao tempo interior do sujeito: as águas passam, ou seja, a chuva escorre pelos telhados e o Eu apenas observa, cansado e estático.

No primeiro verso de "Meus olhos apagados", o poeta refere-se aos olhos apagados que vêem a chuva; essa mesma expressão é repetida na segunda estrofe. Já na terceira estrofe, temos a presença dos olhos, porém não é a mesma expressão. Os olhos e o olhar aparecem constantemente na obra de Pessanha e ajudam na composição do íntimo do sujeito poético na medida em que são, quase sempre, qualificados com adjetivos que expressam sentimentos humanos como tristeza e cansaço. Visto que os olhos podem ser entendidos como comunicação entre o interior do Eu e o exterior, o olhar em Pessanha é forma de comunicação, ponte entre a objetividade, o que o poeta vê, e a subjetividade, o que ele sente, ou seja, o que as imagens provocam nele.

O olhar, lembremos, também está presente no soneto analisado de Verlaine: tem-se um indivíduo que contempla um mundo com o qual e no qual não consegue se ajustar, por 
isso fica alheio à realidade. De modo diferente dos poemas de Pessanha, em Verlaine, muitas vezes, a questão do olhar aparece implícita, é o leitor que precisa concluir que por trás da descrição das paisagens existe um sujeito poético que observa e analisa constantemente o mundo ao seu redor.

No poema "Meus olhos apagados", apesar da alusão freqüente aos olhos apontar para um sujeito que contempla o mundo ao seu redor, as referências espaciais são mínimas. Constantemente, nos poemas de Pessanha, as questões do intimismo são tão fortes que o espaço externo apenas reitera o que é da ordem do interior do eu. Ao contemplar a realidade exterior, a importância dos objetos desaparece e o foco volta para o interior do eu - sobretudo porque o que se sabe do exterior é pela via do olhar do eu e pela projeção do seu íntimo na conjuntura observada.

Nos versos "Meus olhos apagados/Vede a água cahir", o poeta vale-se do recurso da sinédoque quando se serve do elemento olho para se designar todo o eu do sujeito poético. Essa técnica de qualificar uma parte significativa como os olhos, o coração, a alma para designar todo o indivíduo e auxiliar na construção da imagem do sujeito poético é recorrente nos poemas de Clepsidra. Ora, os olhos apagados são parte de um sujeito que está inteiramente apagado e a falta de luz sugere a ausência de vida. Na segunda estrofe, os últimos versos ("Meus olhos apagados,/E cançados de ver”) também qualificam os olhos como cansados; na verdade, é todo o sujeito poético que está cansado, pois tem de esperar o transcorrer do tempo para morrer e, assim, deixar de sofrer.

A segunda estrofe retoma e desenvolve a primeira. O poeta utiliza-se de um recurso estilístico muito comum em sua obra que é a iteração, ou seja, repete as palavras ou até os mesmos versos em posições diferentes. Os únicos elementos novos inseridos são apenas "quasi morrer" e "cançados de ver" - que, entretanto, dizem muito - como podemos observar abaixo: 
Meus olhos apagados,

Vede a água cahir.

Das beiras dos telhados,

Cahir, sempre cahir.

Das beiras dos telhados,

Cahir, quasi morrer...

Meus olhos apagados,

E cançados de ver.

A repetição causa monotonia e ilustra o tédio do sujeito poético que enxerga tudo sempre igual. O advérbio de tempo "sempre", que aparece no quarto verso, aponta para esse pesar: o sujeito que tem a noção temporal deturpada, enxerga nas coisas o presente contínuo, um período temporal longo que nunca acaba. Sem dúvida, a percepção temporal é subjetiva e tal subjetivação agudiza-se mais pelo fato de o sujeito poético estar sofrendo e também estar cansado da realidade circundante.

As reticências, que aparecem no segundo verso da segunda estrofe, "Cahir, quasi morrer...", são significativas; elas prolongam a languidez dos versos, pois dão a impressão de que não há forças para completar uma frase ou um pensamento. Além disso, depois de morrer não há muito o que dizer ou esperar pois o eu alcançou o que desejava. Portanto, nos dois primeiros quartetos, estamos diante de um indivíduo com olhar enclausurado, entediado e cansado da realidade. O sujeito poético é formado, quer pelos elementos formais que sugerem languidez, quer pela repetição do léxico, como alguém que não participa da realidade; ao contrário, mantém-se alheio a ela e recolhe-se em si mesmo. Essa apatia do sujeito poético aparece constantemente na obra de Pessanha, como já evidenciado no capítulo dedicado à sua obra.

Tendo em vista a falta de forças, o cansaço e o tédio do sujeito poético de "Meus olhos apagados", podemos dizer que este ele está imerso no langor, o mesmo sentimento do sujeito poético ilustrado no poema de Verlaine. Em ambos, o eu permanece à distância, 
à margem, apenas contemplando o tempo passar. Portanto, embora os poetas utilizem procedimentos estético-formais diferentes, o tema da transitoriedade, do cansaço da espera e do distanciamento do homem em relação ao mundo está presente tanto no poema de Verlaine como no de Pessanha.

A última estrofe de "Meus olhos apagados" ilustra o auge da apatia do sujeito poético que não tem forças sequer para chorar:

Meus olhos, afogae-vos

$\mathrm{Na}$ vã tristeza ambiente.

Caí e derramae-vos

Como a água morrente.

Os verbos estão no imperativo, portanto, é o sujeito poético que ordena aos seus olhos que chorem, que se derramem como a água da chuva derrama-se no e do telhado. $\mathrm{O}$ campo lexical dessa ultima estrofe é todo aquoso, até mesmo os verbos "afogar" e “derramar” trazem em si a idéia de água.

A caracterização da água como "morrente" é singular no poema e fundamental para construção da imagem do sujeito poético desencantado, pois o desencanto com a realidade e a abulia são tão intensos que ele mesmo encontra-se num estado de quase morto, ou seja, morrente. A água é qualificada como morrente, pois está a caminho da morte, mas ela ainda não vai morrer, pois não completou o seu ciclo. A chuva cai, escorre dos telhados, alcança os rios e chega ao mar, este é o símbolo da reintegração, a união da gota com o mar. Assim como a água, o indivíduo precisa esperar o transcorrer do seu ciclo, ou seja, da sua vida, para poder se reintegrar, ir ao encontro do cosmos através da morte, assim como a gota de chuva vai ao encontro do mar. Por isso, a qualificação "morrente" - que indica aquele que está a caminho da morte, "indo morrer". 
Em relação à contemplação da água, Gaston Bachelard afirma que "contempler l'eau c'est s'écouler, c'est dissoudre, c'est mourrir" ${ }^{80}$ podemos dizer que a própria ação do sujeito poético em contemplar aquilo que esvai, em contemplar a água é, ao fim e ao cabo, desejar ser como ela, é deixar-se ir, esvair-se, o que significa morrer.

Na última estrofe, a epígrafe é retomada, uma vez que, assim como Verlaine, o poeta relaciona o choro à chuva. As lágrimas devem derramar-se dos olhos do sujeito poético assim como a água da chuva cai do telhado. A tristeza ambiente desse poema de Pessanha nos remete ao "sol lânguido" do soneto de Verlaine e, desse modo, temos, além de mais uma aproximação entre o vate português e o francês, outro exemplo de impressionismo, ou seja, das sensações íntimas do Eu transpostas e impressas no ambiente descrito. O tédio e o desencanto do sujeito que imperativamente diz aos seus olhos "Cahi e derramae-vos / Como água morrente" remetem-nos ao sujeito poético de "Langueur", que afirma: "Seul, un ennui d'on ne sait quoi qui vous afflige!"

A possibilidade de aproximação das obras de Paul Verlaine e de Camilo Pessanha aponta, a nosso ver, para convergências de pensamentos de uma época, como afirma a crítica Anna Balakian:

com o Simbolismo a arte deixou realmente de ser nacional e assumiu as premissas da cultura ocidental. Sua preocupação maior era o problema não temporal, não sectário, não geográfico e não racional da condição humana: o confronto entre a mortalidade humana com o poder de sobrevivência, através da preservação das sensibilidades humanas nas formas artísticas ${ }^{81}$.

Assim o que mais importa para nós não é a questão da recepção da obra de Verlaine, ou seja, se Pessanha foi leitor de Verlaine, porém como eles lidaram com os

\footnotetext{
${ }^{80}$ BACHELARD, Gaston, L'eau et les rêves, citado por Álvaro GOMES, in A metáfora Cósmica em Camilo Pessanha, p. 80.

${ }^{81}$ BALAKIAN, Op. cit., p. 15
} 
preceitos simbolistas, cada um a sua maneira, já que as particularidades, especialmente nas poéticas de modernidade, são naturais, pois, como afirma Edmund Wilson,

Cada poeta tem uma personalidade única; cada um de seus momentos possui seu tom especial, sua combinação especial de elementos. É tarefa do poeta descobrir, inventar, a linguagem especial que seja a única capaz de exprimir-lhe a personalidade e percepções. Essa linguagem deve lançar mão de símbolos: o que é tão especial, tão fugidio e tão vago, não pode ser expresso por exposição ou descrição direta, mas somente através de uma sucessão de palavras, de imagens que servirão para sugeri-lo ao leitor (...) E o Simbolismo pode ser definido como uma tentativa, através de meios cuidadosamente estudados - uma complicada associação de idéias, representa por uma miscelânea de metáforas - de comunicar percepções únicas e pessoais. ${ }^{82}$

Desse modo, a nosso ver, a denominação de "Verlaine Português" a Camilo Pessanha, que se deve justamente ao uso que Pessanha faz das estruturas formais e da musicalidade, soa como simplista e reducionista, pois é diminuir o valor da obra do poeta português em relação ao francês. Além disso, tal denominação não leva em conta as características da obra de Verlaine e de Pessanha, resumindo-se a classificá-los apenas pelo uso dos elementos formais.

A aproximação entre esses dois poetas é pertinente, mas não deve ser simplista e nem reducionista. $\mathrm{O}$ exame atento da obra dos dois autores, através da análise de poemas, permite estabelecer que o diálogo entre a obra dos dois poetas é possível, mas constrói-se de semelhanças e diferenças. A relação de diálogo, como apontamos, ultrapassa as camadas superficiais do poema, mais do que a possibilidade de aproximação pelo emprego dos recursos que imprimem sonoridade à poesia, parece-nos permitido aproximá-los também quer pelos temas quer pela maneira de apresentá-los, pois como vimos na análise dos poemas, muitas vezes os recursos formais utilizados pelos poetas são divergentes,

\footnotetext{
${ }^{82}$ WILSON, Edmund, “O Simbolismo”, O Castelo de Axel. São Paulo: Ed. Cultrix, [s.d.], p. 22
} 
nesse caso, como quisemos mostrar, a convergência revela-se na construção do sujeito poético desajustado e desencantado e na noção de tempo. 


\section{REFERÊNCIAS BIBLIOGRÁFICAS}

\section{CORPUS POÉTICO}

BAUDELAIRE, Charles. Les fleurs du mal. Paris: Librio, 2002.

As flores do mal. (Trad. Ivan Junqueira). São Paulo: Nova Fronteira, 1985

Oeuvres Complètes. Paris: Du Seuil, 1991.

CASTRO, Eugênio. Obras completas. 5 5 ed, Rio de Janeiro: Nova Aguilar, 1986.

LORRAIN, Jean. Bathylle. Disponível em www.poesie-érotique.net/JeanLorrain, em 18 de agosto de 2008.

MALLARMÉ, Stéphane. Oeuvres Complètes. Paris: Gallimard - Pléiade, 1984.

NOBRE Antônio. Só, 5a ed., Porto: Araújo \& Sobrinho, 1931.

PESSANHA, Camilo. Clepsidra. (edição crítica de Paulo Franchetti). Lisboa: Editora Relógio D’Água Editores, 1995.

RIMBAUD, Arthur. Oeuvres Complètes. Paris: Gallimard - Pléiade, 1983.

VERDE, Cesário. O livro de Cesário Verde. Rio de Janeiro: Nova Aguilar, 1976. 
VERLAINE, Paul. Jadis et Naguère. In: Oeuvres Poétiques Completes. Paris: Gallimard Pléiade, 1948.

Poèmes Saturniens. In: Oeuvres Poétiques Completes. Paris: Gallimard - Pléiade, 1948.

Oeuvres Poétiques Completes. Paris: Gallimard - Pléiade,[s.d.]

Verlaine - Passeio Sentimental - Poemas ( Tradução de Almansur Haddad). São

Paulo: Círculo do Livro, [s/d]

BIBLIOGRAFIA ESPECÍFICA SOBRE O FIM DE SÉCULO E OS AUTORES OBJETO-DE-ESTUDO.

AA. VV. Centauro. Edição Facsimilada. Lisboa: Editora Contexto, 1982.

AA. VV. A Phala. Um Século de Poesia (1888-1988). Lisboa: Assírio \& Alvim, 1988.

AA. VV. Nova Renascença [Os Simbolismos]. Porto, números 35 a 38, Julho de 1989 / Julho de 1990.

AA. VV. Persona. Porto: Centro de estudos pessoanos, número 10, junho de 1984. 
AA. VV. Persona. Porto: Centro de estudos pessoanos, número 11/12, julho de 1985.

AMORA, A. Soares. O Simbolismo. 5aed. São Paulo: Difel, s/d.

AMARAL, Fernando P. A poesia como doença da alma. Colóquio/Letras, Lisboa, Imprensa Nacional Casa da Moeda, números 127/128, pp.77-85, 1993.

$\mathrm{Na}$ órbita de Saturno (um ponto de vista sobre a melancolia e suas relações com alguma literatura). Revista da faculdade de Letras, Lisboa, número 9, $5^{\mathrm{A}}$ série, pp.33-45, abril de 1688 .

ANDRADE, Eugênio de. Camilo Pessanha, o Mestre. Persona, Porto, número 10, p. 10, jun. de 1984.

BALAKIAN, Anna. O Simbolismo. São Paulo: Ed. Perspectiva, 1995.

BARREIROS. Danilo. O Caderno de Camilo Pessanha. Persona, Porto, números 10, p. 86, jun. 1984.

BARRETO, Guilherme Moniz. A literatura portuguesa no século XX (1889). Lisboa: Editorial Inquérito. [s/d]

BELCHIOR, Maria de Lourdes. Verlaine e o Simbolismo em Portugal. Brotéria, vol. 90, numero 3, pp. 305-319, março de 1970. 
BENJAMIN, Walter. Paris, capital do século XIX. In: Sociologia. São Paulo: Ática, 1985, pp.30-43.

BENTO, José. Duas notas sobre Camilo Pessanha. O tempo e o Modo, Lisboa, no 54/55, pp.832-837, 1997

Outra vez o tema da água na poesia de Camilo Pessanha. Persona, Porto, $\mathrm{n}^{\circ} 10$, pp. 12-16, 1984.

BERTRAND, Marchal. Lire le Symbolisme. Paris : Dunod, 1993.

BOREL, Jacques. Prefácio. In : VERLAINE, Paul. Fêtes Galantes. Romances sans Paroles (Precede de Poèmes Saturniens). Paris: Gallimard, 1999.

CABRAL, António. Pessanha, um poeta Desistente. In: O Primeiro de Janeiro. Porto: 1967.

CAMILO, João. A Clepsidra de Camilo Pessanha. Persona, Porto, nº 10, pp. 20-33, 1984. Sobre a Abulia de Camilo Pessanha. Persona, Porto, números 11-12, pp. 67-75. 1985.

CAROLlO, Cassiana. O Simbolismo. São Paulo: LTC/EDUSP 
CASTRO, Eugénio de. Prefacio da segunda edição. In: Obras Poéticas. Vol. I. Lisboa: Parceira A. M. Pereira, Ltda. 1968, pp. 11-14.

CATROGA, Fernando. O decadentismo finissecular. In: Sociedade e Cultura Portuguesa II. Lisboa: Universidade Aberta, 1996, pp. 245-259.

CARVALHAL, Tânia Franco. Literatura Comparada. São Paulo: Ática, 1996.

CIDADE, Hernani. O conceito de poesia, do Parnaso ao Simbolismo. In: O conceito de poesia como expressão de cultura. São Paulo: Livraria Acadêmica, Saraiva e Cia., 1946, pp.247-280.

COELHO, Jacinto do Prado. De Verlaine a Camilo Pessanha e a Fernando Pessoa. In: Ao Contrário de Penélope. Lisboa: Livraria Bertrand, 1976, pp. 209-214.

COELHO, Maria Teresa Pinto. Apocalipse e regeneração: o Ultimatum e a mitologia da Pátria na literatura finissecular. Lisboa: Edições Cosmos, 1996.

COUTINHO, Luís Edmundo Bouças. O Labirinto finissecular e as idéias do Esteta. Rio de Janeiro: 7 Letras, 2004.

CUNHA, Celso. Sobre o decassílabo em Camilo Pessanha. In: Língua e Verso. Rio de Janeiro: Livraria São José, 1990. 
DIAS, Maria Heloísa Martins. Poesia de Camilo Pessanha: A Permanência do que se Nega a Permanecer - O Tempo e seu Fluir. A Cristalização do Instante. Boletim Informativo do centro de Estudos Portugueses, São Paulo, $2^{\mathrm{a}}$ série, número 7, pp.12-41, 1979.

FERNANDES, Maria da Penha Campos. Camilo Pessanha, poeta órfico. Diacrítica, Universidade do Minho (Revista do Centro de Estudos Portugueses), número 6, pp. 227-238, 1991.

FIGUEIREDO, Fidelino de. Simbolismo, Nacionalismo e historicismo: conspecto geral. In: História Literária de Portugal (Século XII-XX). Coimbra: Ed. Nobel. 1944 pp. 435-445.

FRANCHETTI, Paulo Elias Allane. A Clepsidra de Camilo Pessanha: Uma proposta de estabelecimento de texto. Tese de doutorado. São Paulo: Universidade de São Paulo, 1992.

Nostalgia, Exílio e Melancolia. São Paulo: Edusp, 2001.

Camilo Pessanha - Algumas Considerações em Contributo à sua Biografia.

Estudos Portugueses e Africanos, Campinas, n. 21, p. 5-28, $1^{\circ}$ semestre de 1993.

FRANCO, Iberê G. Véus, Caminho para uma Leitura de Camilo Pessanha. Boletim Informativo do Centro de Estudos Portugueses, São Paulo, $2^{a}$ série, número 7, pp.4248, 1979. 
GARCEZ, Maria Helena Neri. Do Simbolismo em Portugal e no Brasil [Posfácio]. In: PEYRE, Henri. A Literatura Simbolista. São Paulo: Ed. Cultrix / Ed. da USP, 1983, pp. 91-105.

Singularidades de um simbolista português. Colóquio/Letras, Lisboa, Fundação Calouste Gulbenkian nº 127/128, pp. 53-64, 1993.

GOMES, Álvaro Cardoso. O tempo na poesia simbolista. 1980. Tese de Livre-docência, Universidade de São Paulo, São Paulo, 1980.

A Metáfora Cósmica em Camilo Pessanha. Tese de Doutorado, 1978, Universidade de São Paulo, São Paulo, 1978.

A estética simbolista. São Paulo: Ed. Atlas. 1994.

GUIMARÃES, Fernando. Poética do Simbolismo Portugal. Lisboa: Imprensa NacionalCasa da Moeda, 1990.

Camilo Pessanha e os caminhos de transformação da poesia portuguesa. In: Simbolismo, Modernismo e Vanguardas. Lisboa: Imprensa Nacional - Casa da Moeda, 1982, pp. 25-43.

Simbolismo, Modernismo e Vanguardas. Lisboa: Imprensa Nacional - Casa da Moeda, 1982. 
HATERLY, Ana. Breve Introdução ao Simbolismo Português - Seguida de Dez leituras Específicas dum Poema de Camilo Pessanha. In: O Espaço Crítico do Simbolismo à Vanguarda. Lisboa: Ed. Caminho. 1979.

HAUSER, Arnold. Impressionismo. In: História Social da Arte e da Literatura. São Paulo: Ed. Martins Fontes, 1995, pp. 894-955.

JÚDICE, Nuno. Da afirmação simbolista à decadência. Centauro (Edição Facsimilada), Lisboa, Editora Contexto, pp. VII-XVI 1982.

LAGARDE, André e MICHARD, Laurent. XIXéme siècle - Les grand auters Français du programme. Paris: Bordas, v.5, 1969.

LARANJEIRA, Pires. Musica e Abulia em Camilo Pessanha. Persona, Porto, Centro de Estudos Pessoanos, número 10, pp. 39-40, jul. 1984.

LEMOS, Esther. A Clepsidra de Camilo Pessanha. Porto: Livraria Tavares Martins. 1956.

LOPES, Óscar. Entre Fialho e Nemésio (estudos de literatura portuguesa contemporânea), vol. I. Lisboa: Imprensa nacional/Casa da Moeda, 1987.

O Quebrar dos Espelhos. In: Ler e Depois. 2ªd, Porto: Editorial Inova, 1969, pp. 198-210.

LOPES, Teresa Coelho. Clepsidra de Camilo Pessanha. Lisboa: Seara Nova. 1979. 
MARTINS, Fernando Cabral. Poesia Simbolista Portuguesa. Lisboa: Editorial Comunicação, 1990.

MÁTTAR, João. O processo Simbólico na Clepsidra de Camilo Pessanha. São Paulo: Centro de Estudos Portugueses da USP, 1996.

MENDES, Mauro. Virgílio e os Cantadores. Disponível em WWW.cronopios.com.br/anexos/virgílio_mauromendes, em 12 de maio de 2008.

MICHAUD, Guy. Doctrine Symboliste, Paris, Nizet, 1947

Message Poétique du Symbolisme. Paris: Nizet, 1966

MONTALVÔR, Luiz. Tentativa de um ensaio sobre a decadência. Centauro (Edição Facsimilada.), Lisboa, Editora Contexto, pp. 8-11. 1982.

MONTEIRO, Adolfo Casais. A poesia Portuguesa Contemporânea. Lisboa: Sá da costa, 1977.

NAVA, Luís Miguel. A Propósito duma Imagem de Pessanha. Persona, Porto, número 10, pp. 34-35, jul. 1984.

NOULET, E. Le ton poétique. Librarie Jóse Corti, 1971. 
OLIVEIRA, Antônio Falcão Rodrigues de. O simbolismo de Camilo Pessanha. Lisboa: Ática, 1979.

PEREIRA, José Carlos Seabra. Decadentismo e Simbolismo na Poesia Portuguesa. Coimbra: Centro de estudos Românicos, 1975.

A Condição do Simbolismo em Portugal e o Litígio das Modernidades. Nova Renacença, Porto, vol. IX, 143-156, ano 1989-1990.

Do fim-de-século ao Tempo de Orpheu. Coimbra: Livraria Almedina, 1979.

PERRONE-MOISÉS, Leila. Camilo Pessanha, Quedas e Cadência. Estudos Portugueses e Africanos, Campinas, número 25-26, pp. 30-39, 1995.

Camilo Pessanha e as miragens do nada. In: Inútil poesia e outros ensaios breves.

São Paulo: Companhia das Letras, 2000, pp. 132-144.

PEYRE, Henry. A Literatura Simbolista. São Paulo: Ed. Cultrix/ Ed. da USP, 1983.

Qu'est -ce que le symbolisme. Paris: Presses Universitaires de France, 1974.

RÉGIO, José. Camilo Pessanha. In: Pequena História da Moderna Poesia Portuguesa. Lisboa: Editorial Inqérito. 1942.

RUBIM, Gustavo. Experiência da Alucinação. Lisboa: Editorial Caminho, 1993. 
Fantasmas do livro. In: Camilo Pessanha - No inclinar da clepsydra. www.camilopessanha.com.sapo.pt

RICHARD, Jean-Pierre. Poésie et Profondeur. Paris: Éditions du Seuil, 1955.

RAYMOND, Marcel. Verlaine, les figures de sa poésie. In: Vérité et Poésie. Paris: Éditions de la Baconnière, [s/d], p. 177-187.

SABATIER, Robert. La Poésie du XIX siècle. Paris: Albin Michel, [s/d]/

SARAIVA, Antônio José \& LOPES, Oscar. História da literatura Portuguesa. $16^{\mathrm{a}}$ ed., Porto: Porto Editora, s/d.

SIMÕES, João Gaspar. I-O movimento simbolista (1890 - 1912). In: Perspectiva histórica da poesia portuguesa (Dos Simbolistas aos Novíssimos). Porto: Brasília Editora. 1976 pp. 13-85.

Camilo Pessanha. Lisboa: Arcádia. 1967.

SPAGgIARI, Barbara. O simbolismo na obra de Camilo Pessanha. Lisboa: Ministério da Educação e das Universidades,1982.

TASSO DE SILVEIRA. A Poesia Simbolista em Portugal. Ocidente, Lisboa, vol 26, pp. 150-158, 1945. 
WILSON, Edmund. O Castelo de Axel. São Paulo: Ed. Cultrix, [s.d.]

\section{BIBLIOGRAFIA SOBRE TEORIA DA POESIA E FILOSOFIA E HISTÓRIA}

ADORNO, Theodor. Lírica e Sociedade. In: Os Pensadores, vol 48. São Paulo: Nova Cultural, 1999.

BACHELARD, Gaston. L'eau et lês rèves 10ª ed, Paris: Librarie José Corti, 1971.

BASTOS, Teixeira. A crise - Estudo sobre a situação política, financeira, econômica e moral da nação portuguesa e suas relações com a crise geral contemporânea. Lisboa: 1894.

BOSI, Alfredo. O ser e o tempo da poesia. São Paulo: Companhia das letras, 2000.

CANDIDO, Antonio. O estudo analítico do poema. São Paulo: Editora da FFLCH/ USP, 1967.

EINAUD, Enciclopédia. Tempo/Temporalidade. Vol. 29. Lisboa: Imprensa Nacional Casa da Moeda, [s/d].

ELIOT, T.S. Tradição e Talento Individual. In: Ensaios. São Paulo: Art Editora, 1989, pp. $37-48$. 
FREUD, Sigmund. Luto e Melancolia. In: Obras Psicológicas completas de Sigmund Freud. Rio de Janeiro: Ed. Imago, 1974, vol XIV, pp.275-91.

O mal estar na civilização. Rio de Janeiro: Imago, 1997 (trad. José Otávio de Abreu).

FRIEDRICH, Hugo. Estrutura da lírica moderna. São Paulo: Duas Cidades, 1978.

GOLDSTEIN, Norma. Versos, Sons e Ritmos. São Paulo: Ática, 2001.

HAUSER, Arnold. História Social da arte e literatura. São Paulo: Martins Fontes. 1995.

HEGEL, G.W.F. Éthétique. Paris: Aubier, éditions montaigne, 1944.

KAISER, Wolfang. Análise e Interpretação da Obra Literária. São Paulo: Martins Fontes, 1976 ( trad. Paulo Quintelo).

LOURENÇO, Eduardo. Psicanálise mítica do destino português. In: O labirinto da saudade. $3^{\circ}$ ed., Lisboa: Dom Quixote, 1998, pp. 17-64.

Poesia e metafísica. Lisboa: Sá da costa editora. 1983.

Tempo e Poesia. Lisboa: Relógio d'Água Editores. [s/]. 
MOISÉS, Massaud. A criação literária: poesia. 11ª ed., São Paulo: Cultrix, 1989.

NITRINI, Sandra. Conceitos fundamentais. In: Literatura Comparada. São Paulo: Edusp, 1997, pp. 125-181.

PAZ, Octavio. Os filhos do Barro. (Trad. Olga Savary). Rio de Janeiro: Nova Fronteira, 1984.

Signos em Rotação. (Trad. Sebastião Uchoa Leite). São Paulo: Editora Perspectiva, 1996.

PERRONE-MOISÉS, Leyla. Flores na Escrivaninha. São Paulo: Companhia das Letras, 1990.

Inútil poesia e outros ensaios breves. São Paulo: Companhia das Letras, 2000.

POULET, Georges. Études sur le Temps Humaine. 4 vols, Paris. Ed. du Rocher, 1976.

POUND, Ezra. ABC da Literatura. (trad. Augusto de campo e José Paulo Paes). São Paulo: Cultix, 1995.

ALI, Manoel Said. Versificação Portuguesa. São Paulo: Edusp, 1999.

SCHOPENHAUER, Arthur. O mundo como Vontade e Representação. In: Os Pensadores. São Paulo: Abril, 1985, pp. 09-82. 
Metafísica do Amor/Metafísica da Morte. São Paulo: Martins Fontes[s/d]( trad. Jair Barbosa)

SERRÃO, Joel. Em torno da experiência oitocentista do tédio. In: Temas Oitocentistas.

Vol. II. Lisboa: Livros Horizonte, 1978, pp. 11-45. 


\section{ANEXO - Tradução dos Poemas}

1. Quando às cidades ele vai, tal qual um poeta,

Eis que redime até a coisa mais abjeta,

E adentra como rei, sem bulha ou serviçais,

Quer os palácios, quer os tristes hospitais. ${ }^{83}$

2. Quero, para compor meus castos monólogos,

Deitar-me ao pé do céu, assim como os astrólogos,

E, junto aos campanários, escutar sonhando

Solenes cânticos que o vento vai levando.

As mãos sob meu queixo, só, na água-furtada,

Verei a fábrica em azáfama engolfada;

Torres e chaminés, os mastros da cidade,

E o vasto céu que faz sonhar a eternidade.

É doce ver, em meio à bruma que nos vela,

Surgir no azul a estrela e a lâmpada à janela,

Os rios de carvão galgar o firmamento

$E$ a lua derramar seu suave encantamento.

Verei a primavera, o estio, o outono; e quando,

Com seu lençol de neve, o inverno for chegando,

Cada postigo fecharei com férreos elos

Para na noite erguer meus mágicos castelos.

Hei de sonhar então com azulados astros,

Jardins onde a água chora em meio aos alabastros,

Beijos, aves que cantam de manhã e à tarde,

E tudo o que no Idílio de infantil se guarde.

O Tumulto, golpeando em vão minha vidraça,

Não me fará volver a fronte ao que se passa,

Pois que estarei entregue ao voluptuoso alento

De um relembrar a Primavera em pensamento,

E um sol na alma colher, tal como quem, absorto,

Entre idéias goza um tépido conforto. ${ }^{84}$

3. O Meretrício brilha ao longo das calçadas

Qual formigueiro ele franqueia mil entradas;

Por toda parte engendra uma invisível trilha,

Assim como o inimigo apronta uma armadilha;

Pela cidade inunda e hostil se movimenta

Como um verme que ao Homem furta o que o sustenta.

Ouvem-se aqui e ali as cozinhas a chiar,

Os teatros a ganir, as orquestras a ecoar;

Curvam-se escroques e rameiras, seus comparsas,

E os ladrões, que perdão ou trégua alguma têm,

${ }^{83}$ BAUDELAIRE, Charles, "O Sol” As flores do mal, (Trad. Ivan Junqueira), São Paulo, Nova Fronteira, 1985, p. 319.

${ }^{84}$ Ibidem, "Paisagem", p. 317. 
Começam cedo a trabalhar, eles também,

Forçando docemente o trinco e a fechadura

Para que a vida não lhes seja assim tão dura. ${ }^{85}$

4. Eu vi que tudo sob o sol é vão! ${ }^{86}$

\section{Arte Poética}

Música sim mas antes de tudo, O Ímpar prefere e jamais o Par, Mais vago e mais solúvel no ar

E sem que nele pese um veludo.

Procurar deves se for preciso Tuas palavras com desamor:

Procura amar a ária furta-cor E que o Preciso une ao Indeciso.

É belo olhar por detrás dos véus, Hora a tremer quando é meio-dia Por uma tarde de outono fria, O caos azul dos astros nos céus!

Na Meia-Tinta a minha parte ponho, Jamais a Cor, só a meia-tinta! Só esperança, a cor indistinta, Frauta à buzina e mais sonho ao sonho!

Deixa bem longe a Ponta daninha, O que é mordaz e a risada impura, Fazem chorar os olhos da Altura,

E todo este alho que há na cozinha!

Mata a eloqüência mas de asfixia! Tendo o valor porém, ó poeta,

De tua Rima tornar discreta,

Sem teu cuidado, aonde ela iria?

E quem dirá os males da Rima? Que criança surda ou que negro louco

Fez esta jóia que vale pouco,

Que soa falso e se toca a lima?

Música ainda, música sempre!

Seja o teu verso algo a voar,

Fuga de uma alma a ir por um ar

De céus de que ninguém mais se lembre.

${ }^{85}$ Ibidem, "O Crepúsculo Vespertino", p. 351.

${ }^{86}$ VERLAINE, Tradução livre do soneto "Vers pour être Calomnié.", Jadis et Naguère, p. 25. 
Seja teu verso esta boa aventura

Esparsa ao vento, cru, matutino,

Que vai florindo menta mais timo...

E tudo o mais é literatura. ${ }^{87}$

6. Canção de outono

As pulsações

Dos violões

Outonais

Fazem o ser

Esmorecer,

Sempre iguais

E todo arfando

Pálido, quando

Soa a hora,

Minha alma invade

Velha saudade

E após chora.

Se eu assim vago,

Vento pressago

Me transporta

Ao-deus-dará,

Semelhante à

Folha morta. ${ }^{88}$

\section{Langor}

Agora sou o Império ao fim da decadência,

Que contempla passarem Bárbaros poentos

Enquanto vai compondo acrósticos cinzentos,

De estilo áureo em que o sol é langor e cadência.

A alma no coração é só tédio e dormência.

Diz-se uivarem além os combates sangrentos.

Oh, não poder, frágil que se é nos votos lentos,

Oh, não querer florir um pouco esta existência!

Oh, não querer, oh, não poder morrer um pouco!

Bátilo, já não ris! Não mais há o que beber!

Tudo é comido enfim! Não mais o que dizer!

Só, um poema infantil que se atira ao fogo,

Só, um criado que não mais se te dirige,

Só, um tédio ignorado e que tanto te aflige! ${ }^{89}$

\footnotetext{
${ }^{87}$ VERLAINE, Paul, "Arte Poética", Verlaine - Passeio Sentimental - Poemas ( tradução de Almansur Haddad), São Paulo, Círculo do Livro, [s/d], p. 126-127.

${ }^{88}$ Ibidem, "Canção do Outono",p.51-52.

${ }^{89}$ Ibidem, "Langor", p. 150.
} 


\section{O Relógio}

Relógio! deus sinistro, hediondo, indiferente, Que nos aponta o dedo em riste e diz: "Recorda!

A Dor vibrante que a alma em pânico te acorda

Como num alvo há de encravar-se brevemente; ${ }^{90}$

9. Os que nasceram sob o signo de Saturno, Fulvo planeta e tão caro à necromancia, Tem sobre os mais, segundo os livros da magia, A alma de sofrimento e de bile repleta.

Têm a imaginação a mais fraca e inquieta Que vêm para anular o esforço da Razão, E nas veias o sangue, esta intoxicação, Queimando como lava e raro, rola e escoa, Fazendo bruxulear o ideal que se esboroa. Devem sofrer desta maneira os Saturnais E morrer - aceitar que sejamos mortais -, Cada linha da mão encerra-lhes o signo Por lógica fatal de algum fado maligno. ${ }^{91}$

\section{Alegoria}

Déspota, pesado, incolor, o Verão

Como um rei preguiçoso preside um suplício,

Se estira pelo ardor branco do céu cúmplice

E boceja. O homem dorme longe do trabalho abandonado.

A cotovia da manhã, lassa, não cantou.

Nem uma nuvem, nem um sopro, nada que deforme

Ou perturbe este azul implacavelmente liso

Onde o silencio almeja a imobilidade.

$\mathrm{O}$ amargo entorpecimento ganhou as cigarras

E sobre o estreito leito delas de pedras desiguais

Os riachos meio secos não correm mais.

Uma rotação incessante de miragens

Luminosas estendem seus fluxos e seus refluxos...

As vespas, aqui e ali, voam, amarelas e pretas. $^{92}$

11. Sóis poentes

Uma aurora fria

Verte na vertente

\footnotetext{
${ }^{90}$ BAUDELAIRE, "O Relógio", Op. cit, p. 313

${ }^{91}$ VERLAINE, Op. cit, 35.

${ }^{92}$ VERLAINE, Tradução livre, "Allégorie”, Jadis et Naguère, p. 22.
} 

A melancolia
De um sol poente. ${ }^{93}$

12. Imóveis, baixemos nossos olhos para nossos joelhos. Não pensemos, sonhemos. Deixemos a vontade A felicidade que foge e o amor que se esvai, E nossos cabelos tocados pelas asas das corujas. ${ }^{94}$

13. Ah! Porque nossa sorte é bem completa, que enfim A esperança está abolida, a derrota certa,

E que o esforço mais enorme será vão,

E porque é feito mesmo de nossa raiva. ${ }^{95}$

\footnotetext{
${ }^{93}$ Ibidem, "Sóis Poentes", p. 48

${ }^{94}$ VERLAINE, Tradução livre, "Circonspection", Jadis et Naguère, p. 24.

${ }^{95}$ VERLAINE, Tradução livre, "Les Vaincus", Jadis et Naguère, p.77.
} 